\title{
A Summary of Nuclear Fuel Reprocessing Activities Around the World
}

\author{
P. J. Mellinger \\ K. M. Harmon \\ L. T. Lakey
}

November 1984

Prepared for the U.S. Department of Energy under Contract DE-AC06-76RLO 1830

Pacific Northwest Laboratory Operated for the U.S. Department of Energy by Battelle Memorial Institute 


\title{
DISCLAIMER
}

This report was prepared as an account of work sponsored by an agency of the United States Government. Neither the United States Government nor any agency thereof, nor any of their employees, makes any warranty, express or implied, or assumes any legal liability or responsibility for the accuracy, completeness, or usefulness of any information, apparatus, product, or process disclosed, or represents that its use would not infringe privately owned rights. Reference herein to any specific commercial product, process, or service by trade name, trademark, manufacturer, or otherwise, does not necessarily constitute or imply its endorsement, recommendation, or favoring by the United States Government or any agency thereof. The views and opinions of authors expressed herein do not necessarily state or reflect those of the United States Government or any agency thereof.

\author{
PACIFIC NORTHWEST LABORATORY \\ operated by \\ BATTELLE \\ for the \\ UNITED STATES DEPARTMENT OF ENERGY \\ under Contract DE-AC06-76RLO 1830
}

\begin{tabular}{|c|c|}
\hline \multicolumn{2}{|c|}{ Printed in the United States of America } \\
\hline \multicolumn{2}{|c|}{ Available from } \\
\hline \multirow{4}{*}{\multicolumn{2}{|c|}{$\begin{array}{c}\text { National Technical Information Service } \\
\text { United States Department of Commerce } \\
5285 \text { Port Royal Road } \\
\text { Springfield, Virginia } 22161\end{array}$}} \\
\hline & \\
\hline & \\
\hline & \\
\hline \multirow{2}{*}{\multicolumn{2}{|c|}{$\begin{array}{c}\text { NTIS Price Codes } \\
\text { Microfiche A01 }\end{array}$}} \\
\hline & \\
\hline \multicolumn{2}{|c|}{ Printed Copy } \\
\hline & Price \\
\hline Pages & Codes \\
\hline $001-025$ & $\mathrm{~A} 02$ \\
\hline $026-050$ & $\mathrm{~A} 03$ \\
\hline $051-075$ & $\mathrm{~A} 04$ \\
\hline $076-100$ & A05 \\
\hline $101-125$ & A06 \\
\hline $126-150$ & $\mathrm{~A} 07$ \\
\hline $151-175$ & $\mathrm{~A} 08$ \\
\hline $176-200$ & A09 \\
\hline $201-225$ & A010 \\
\hline $226-250$ & A011 \\
\hline $251-275$ & A012 \\
\hline $276-300$ & A013 \\
\hline
\end{tabular}


A SUMMARY OF NUCLEAR FUEL REPROCESSING ACTIVITIES AROUND THE WORLD

\author{
P. J. Mellinger \\ K. M. Harmon \\ L. T. Lakey
}

November 1984

Prepared for

the U.S. Department of Energy under Contract DE-AC06-76RLO 1830

Pacific Northwest Laboratory

Richland, Washington 99352 


\section{CONTENTS}

ACRONYMS AND ABBREVIATIONS $\ldots \ldots \ldots \ldots \ldots \ldots \ldots \ldots \ldots \ldots \ldots \ldots \ldots \ldots \ldots \ldots \ldots$

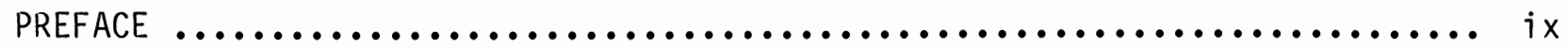

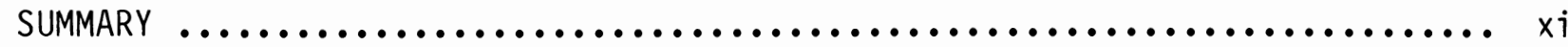

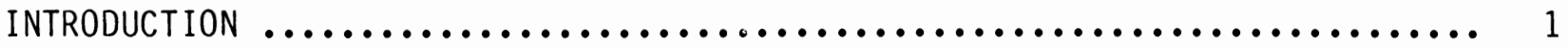

NATIONAL NUCLEAR PROGRAMS INVOLVING REPROCESSING $\ldots \ldots \ldots \ldots \ldots \ldots \ldots \ldots \ldots \ldots$

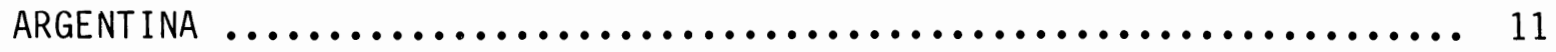

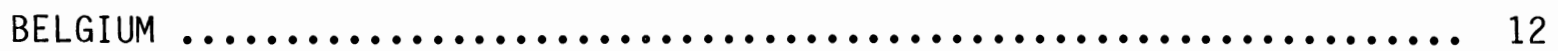

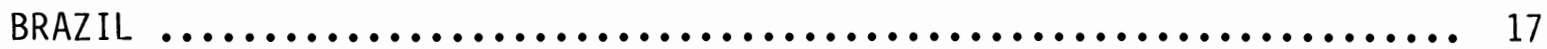

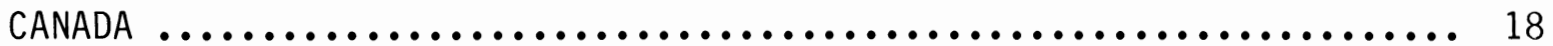

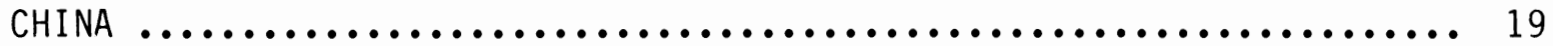

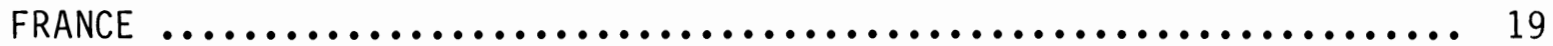

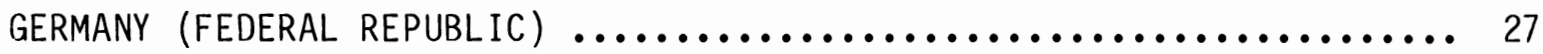

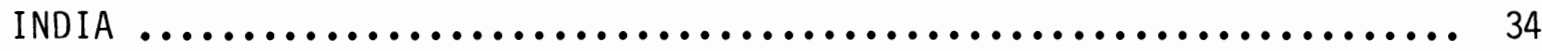

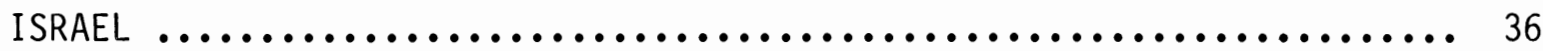

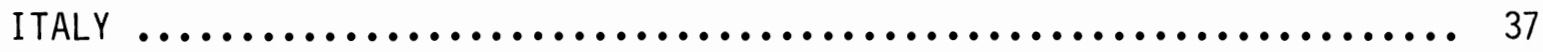

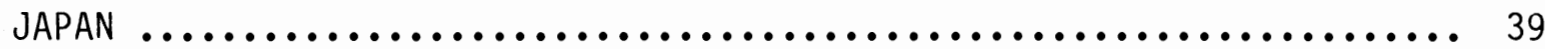

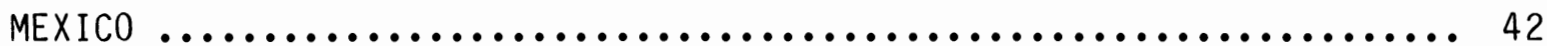

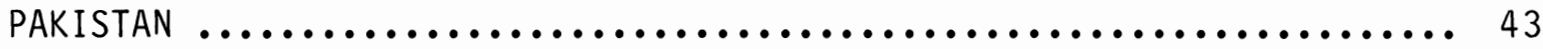

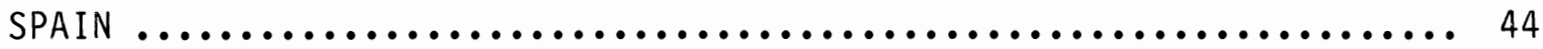

UNION OF SOVIET SOCIALIST REPUBLICS (USSR) $\ldots \ldots \ldots \ldots \ldots \ldots \ldots \ldots \ldots \ldots$

UNITED KINGDOM $\ldots \ldots \ldots \ldots \ldots \ldots \ldots \ldots \ldots \ldots \ldots \ldots \ldots \ldots \ldots \ldots \ldots \ldots \ldots \ldots$

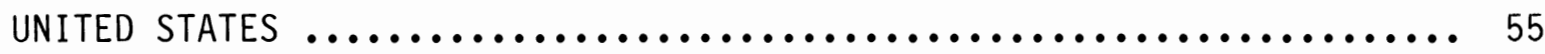

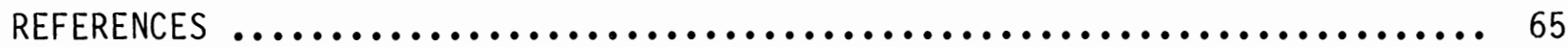




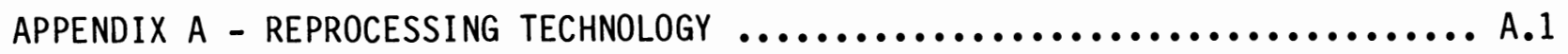

APPENDIX B - ADVANCED PILOT PLANT, COMMERCIAL, AND MILITARY REPROCESSING FACILITIES $\ldots \ldots \ldots \ldots \ldots \ldots \ldots \ldots \ldots \ldots \ldots \ldots \ldots . \ldots . \ldots . \ldots$ 
ACRONYMS AND ABBREVIATIONS

AEC

Atomic Energy Commission (US)

AECL

Atomic Energy of Canada, Limited

AEE-Winfrith

Atomic Energy Establishment-Winfrith (UK)

AERE-Harwel1

Atomic Energy Research Establishment-Harwell (UK)

AFR

Away-from-reactor spent fuel storage facility

AGIP-S.P.A.

Nuclear fuel cycle company (Italy)

AGR

Advanced gas-cooled reactor, $\mathrm{UO}_{2}$ fuel (UK)

ANDRA

French waste management company

AT -1

Small French breeder reprocessing pilot plant at La Hague

ATR

Advanced Thermal Reactor, heavy-water moderated (Japan)

AVM

BMFT

French HLW vitrification system at Marcoule

BNFL

Ministry for Science and Technology (FRG)

BNFP

British Nuclear Fuels Limited (UK)

BRET

Barnwell Nuclear Fuel Plant (US)

BUTEX

Breeder Reprocessing Engineering Test (US)

BWR

Dibutyl carbitol solvent extraction process (UK)

CANDU

Boiling water reactor

CEA

Canada Deuterium Uranium reactor

CEN/SCK

French Atomic Energy Commission

CMEA

CNEA

Belgian Nuclear Research Center at Mo 1

Council for Mutual Economic Assistance (Eastern bloc countries)

CNEN

Comisión National de Energía Atomica (Argentina)

COGEMA

National Nuclear Energy Commission (Brazil)

French fuel cycle company

DF

Decontamination factor

DOG

Dissolver off-gas

DWK

German nuclear fuel reprocessing company

DWPF

Defense Waste Processing Facility at SR (US)

EDF

ENEA

Electricite de France - French utility

ENEL

National commission for energy research and development (Italy)

EUREX

National corporation for electrical energy (Italy)

Italian fuel reprocessing pilot plant 


\begin{tabular}{|c|c|}
\hline EURODIF & Enrichment consortium (France, Italy, Belgium, Spain) \\
\hline FBR & Fast breeder reactor \\
\hline FBTR & Fast Breeder Test Reactor (India) \\
\hline FRG & Federal Republic of Germany \\
\hline GCHWR & Gas-cooled, heavy water moderated reactor \\
\hline GCR & Gas-cooled, graphite moderated reactor \\
\hline GWe & $10^{9}$ watts of electricity (1000 MWe) \\
\hline HAO & Oxide head-end plant (La Hague reprocessing plant, France) \\
\hline HEU & High-enriched uranium \\
\hline HM & Heavy metal (uranium, plutonium, etc.) \\
\hline HLW & High-level waste (first cycle waste in a reprocessing plant) \\
\hline HTGR & High-temperature, gas-cooled reactor \\
\hline HTR & High-temperature reactor \\
\hline HWR & Heavy water reactor \\
\hline ICPP & Idaho Chemical Processing Plant (US) \\
\hline ILW & Intermediate-level waste \\
\hline INFCE & International Fuel Cycle Evaluation \\
\hline ITREC & Italian fuel reprocessing pilot plant \\
\hline JNFS & Japan Nuclear Fuel Services Co. \\
\hline JUPITER & HTGR fuel reprocessing facility (FRG) \\
\hline KFA & Nuclear research center at Jülich (FRG) \\
\hline KfK & Nuclear research center at Karlsruhe (FRG) \\
\hline LAHDE & Remote maintenance test facility (FRG) \\
\hline LEU & Low-enriched uranium \\
\hline LGR & Water-cooled, graphite-moderated reactor \\
\hline LLW & Low-level waste \\
\hline LMFBR & Liquid metal fast breeder reactor \\
\hline LWR & Light water reactor \\
\hline Magnox & Magnesium-aluminum alloy used for GCR fuel cladding (UK) \\
\hline MFRP & Midwest Fuel Recovery Plant (US) \\
\hline MOX & Mixed (plutonium/uranium) oxide \\
\hline MTR & Materials test reactor \\
\hline$M W d / t$ & Megawatt days per tonne \\
\hline MWe & Megawatts electric \\
\hline
\end{tabular}




\begin{tabular}{|c|c|}
\hline MWt & Megawatts thermal \\
\hline NEA & Nuclear Energy Agency (an OECD agency) \\
\hline NEZ & Center for the disposal of spent nuclear fuel (FRG) \\
\hline NFRRC & Nuclear Fuel Recovery and Recycling Center (US) \\
\hline NFS & Nuclear Fuels Services (US) \\
\hline NIRAS/ONDRAF & National waste management company (Belgium) \\
\hline OECD & Organization for Economic Cooperation and Development \\
\hline PAMELA & FRG vitrification pilot plant (Mol, Belgium) \\
\hline PEC & Fast test reactor (Italy) \\
\hline PFR & Prototype Fast Reactor (UK) \\
\hline PNC & Power Reactor and Nuclear Fuel Development Corporation (Japan) \\
\hline PUREX & Plutonium and uranium extraction ( $\mathrm{Pu} / \mathrm{U}$ separations process) \\
\hline PWR & Pressurized water reactor \\
\hline SAP & French reprocessing pilot plant at Marcoule \\
\hline SGN & French fuel cycle company \\
\hline SS & Stainless steel \\
\hline$t$ & Metric ton (tonne) \\
\hline TBP & Tributyl phosphate \\
\hline TEXO & $\begin{array}{l}\text { Facility for testing of and training on full-scale fuel } \\
\text { reprocessing equipment ( } F R G)\end{array}$ \\
\hline tHM & Metric tons of heavy metal \\
\hline THOREX & Thorium extraction process \\
\hline THORP & Thermal Oxide Reprocessing Plant (UK) \\
\hline TLA & Trilaurylamine \\
\hline TOR & Breeder fuel reprocessing pilot plant at Marcoule (France) \\
\hline TRU & Transuranic \\
\hline tU & Metric tons $U$ \\
\hline UKAEA & United Kingdom Atomic Energy Authority \\
\hline UP1 & French reprocessing plant at Marcoule \\
\hline UP2 and UP3 & French reprocessing plants at La Hague \\
\hline WAK & German fuel reprocessing plant at Karlsruhe \\
\hline
\end{tabular}




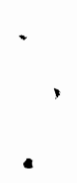




\section{PREFACE}

This review of international practices for nuclear fuel reprocessing was prepared as part of the International Program Support Office activities sponsored by the U.S. DOE at Pacific Northwest Laboratory in Richland, Washington. The objective of the office is to provide a center for collecting, evaluating and disseminating information on international fuel cycle and waste management activities.

This report was prepared to provide a nontechnical summary of the current status of nuclear fuel reprocessing activities around the world. Such a summary is needed as background information for planning U.S. DOE nuclear programs, both domestic and international.

Other than addressing general technical questions, e.g., facility type, technical details have been avoided and the reader is referred to the referenced literature for those details.

The sources of information are widely varied and include the proceedings of international symposia and conferences, papers presented at technical society meetings, topical reports, foreign trip reports, and the news media. When information from source to source is inconsistent, but within reasonable bounds, approximations are presented. As will be obvious to the reader, the information available varies from country to country with the activities in the developed western countries being well documented with only meager information available from the eastern-bloc and less developed countries. 

Fuel reprocessing is the mechanical/chemical operation in the nuclear fuel cycle by which plutonium and unused uranium are recovered from spent nuclear fuel. Seventeen countries are known to be or have been engaged in fuel reprocessing activities. Most are using reprocessing to obtain plutonium for recycle as a fuel in nuclear power stations; five are also using reprocessing to obtain plutonium as a weapons material; two are reprocessing only to obtain plutonium as a weapons material. Most plants are operated by a quasigovernment agency.

As shown in Table 1, at least thirty-two pilot, demonstration or industrial reprocessing facilities are known to have been built; twenty are presently operating. Another thirteen are proposed for operation prior to the year 2000. The units not operating include three built for reprocessing commercial power fuels in the U.S. (NFS, MFRP, and BNFP) and one built for pyrochemical processing of breeder fuel (EBR-II). Throughput capacity of these plants varies from $0.3 \mathrm{~kg} /$ day to multi-tHM/day. Plants for highly-enriched fuels and breeder reprocessing are small; plants for low-enriched fuels are larger, reaching several tonnes per day capacity. Breeder fuels have been reprocessed in four countries--France, Japan, USA, and the United Kingdom.

Plutonium/uranium recovery processes have been developed for four major types of reactor fuels: low- and high-enriched uranium metal and uranium alloys; natural or low-enriched $\mathrm{UO}_{2}$; mixed uranium/plutonium oxides; and mixed uranium/thorium carbides. High-tonnage spent fuels fall in the low-enriched uranium metal and $\mathrm{UO}_{2}$ classes. The metal fuels arise from the graphite- and/or heavy water-moderated reactors used for weapons grade plutonium production and by several nations for civilian power production, while $\mathrm{UO}_{2}$ fuels are used in light- and heavy-water reactors and the advanced graphite-moderated reactors of Great Britain and the USSR.

Most uranium metal fuels for power production are clad in a magnesium or aluminum alloy which does not store well for long periods without special protective measures, and most of the countries with metal-fueled reactors reprocess their spent fuel after a relatively brief cooling period. Hence, the 
TABLE 1. Spent Fuel Reprocessing Plants

\begin{tabular}{|c|c|c|c|c|}
\hline Country & Facility & Mission & $\begin{array}{l}\text { Design } \\
\text { Capacity }\end{array}$ & Operational \\
\hline \multirow[t]{2}{*}{ Argentina } & $\begin{array}{l}\text { Pilot plant } \\
\text { Ezeiza, B.A.) }\end{array}$ & Process demonstration & $20 \mathrm{~kg} / \mathrm{d}$ & Target: \\
\hline & Industrial plant & $\begin{array}{l}\text { Reprocess domestic HWR } \\
\text { fuels }\end{array}$ & $--(a)$ & $\begin{array}{l}\text { Target: late } \\
\text { 1980s }\end{array}$ \\
\hline \multirow[t]{2}{*}{ Brazil } & $\begin{array}{l}\text { Pilot plant } \\
\text { (Rio de Janeiro) }\end{array}$ & Process demonstration & $10 \mathrm{~kg} / \mathrm{d}$ & Target: \\
\hline & Industrial plant & $\begin{array}{l}\text { Reprocess domestic LWR } \\
\text { fuels }\end{array}$ & $300 \mathrm{t} / \mathrm{yr}$ & -- \\
\hline \multirow[t]{3}{*}{ France } & UP1 (Marcoule) & $\begin{array}{l}\text { Reprocess military and } \\
\text { civilian U metal (GCR) } \\
\text { fuels }\end{array}$ & 4.5-6 tHM/d & 1958-present \\
\hline & UP2 (La Hague) & $\begin{array}{l}\text { Treat GCR fuels only } \\
\text { Add LWR capability } \\
\text { Expand LWR capability }\end{array}$ & $\begin{array}{l}5 \mathrm{tHM} / \mathrm{d} \text { (GCR) } \\
1.3 \mathrm{tHM} / \mathrm{d} \text { (LWR) } \\
4 \mathrm{tHM} / \mathrm{d} \text { (LWR) }\end{array}$ & $\begin{array}{l}\text { 1967-present } \\
\text { 1976-present } \\
\text { Target: early } \\
\text { 1990s }\end{array}$ \\
\hline & UP3 (La Hague) & $\begin{array}{l}\text { Reprocess foreign LWR } \\
\text { fuels through 1995; then } \\
\text { treat domestic fuels }\end{array}$ & $4 \mathrm{tHM} / \mathrm{d}$ & Target: $1988 / 9$ \\
\hline
\end{tabular}


TABLE 1. (contd)

\begin{tabular}{|c|c|c|c|c|}
\hline Country & Facility & Mission & $\begin{array}{l}\text { Design } \\
\text { Capacity }\end{array}$ & Operational \\
\hline \multirow[t]{2}{*}{ France (contd) } & SAP (Marcoule) & $\begin{array}{l}\text { Pilot plant: process } \\
\text { development for GCR, } \\
\text { LWR and FBR fuels }\end{array}$ & $25 \mathrm{kgHM} / \mathrm{d}$ & 1962-present \\
\hline & TOR (Marcoule) & $\begin{array}{l}\text { New FBR fuel headend } \\
\text { for SAP }\end{array}$ & $25 \mathrm{kgHM} / \mathrm{d}$ & Target: 1985 \\
\hline \multirow[t]{3}{*}{ Germany (FRG) } & WAK (Karlsruhe) & $\begin{array}{l}\text { Pilot plant for process } \\
\text { and component testing-- } \\
\text { LWR fuels }\end{array}$ & $175 \mathrm{kgHM} / \mathrm{d}$ & 1971-present \\
\hline & Jupiter & $\begin{array}{l}\text { Pilot plant for proces } \\
\text { testing--HTGR fuels }\end{array}$ & $2 \mathrm{kgHM} / \mathrm{d}$ & -- \\
\hline & $\begin{array}{l}\text { WA-350 } \\
\text { (Bavaria or } \\
\text { Lower Saxony) }\end{array}$ & $\begin{array}{l}\text { Commercial plant for } \\
\text { LWR fuels }\end{array}$ & $350 \mathrm{tHM} / \mathrm{yr}$ & Target: 1990 \\
\hline \multirow[t]{3}{*}{ India } & Trombay & $\begin{array}{l}\text { Reprocess test reactor } \\
\text { fuels }\end{array}$ & $0.1-0.15 \mathrm{tHM} / \mathrm{d}$ & $\begin{array}{l}\text { 1964-1974, } \\
\text { 1983-present }\end{array}$ \\
\hline & Tarapur & Reprocess HWR, BWR fuels & $0.5 \mathrm{tHM} / \mathrm{d}$ & 1976-present \\
\hline & Kalpakkam & Reprocess HWR, FBR fuels & $0.5 \mathrm{tHM} / \mathrm{d}$ & -- \\
\hline Israel & Dimona & $\mathrm{Pu}$ production & -- & -- \\
\hline \multirow[t]{2}{*}{ Italy } & $\begin{array}{l}\text { Eurex } \\
\text { (Saluggia Center) }\end{array}$ & $\begin{array}{l}\text { Process demonstration; } \\
\text { reprocess varied fuels }\end{array}$ & $\begin{array}{l}\mathrm{HEU}-30 \mathrm{kgHM} / \mathrm{d} \\
\mathrm{LEU}-100 \mathrm{kgHM} / \mathrm{d}\end{array}$ & 1970-present \\
\hline & $\begin{array}{l}\text { Itrec } \\
\text { (Trisaia Center) }\end{array}$ & $\begin{array}{l}\text { Reprocess Th-U fuel from } \\
\text { US; treat Italian FBR }\end{array}$ & $10-15 \mathrm{kgHM} / \mathrm{d}$ & 1975-present \\
\hline Japan & Tokai-mura & $\begin{array}{l}\text { Develop and test LWR } \\
\text { reprocessing technology }\end{array}$ & $700 \mathrm{kgHM} / \mathrm{d}$ & 1977-present \\
\hline
\end{tabular}


TABLE 1. (contd)

\begin{tabular}{|c|c|c|c|c|}
\hline Country & Facility & Mission & $\begin{array}{l}\text { Design } \\
\text { Capacity }\end{array}$ & Operational \\
\hline \multirow[t]{2}{*}{ Japan (contd) } & JNFS plant & $\begin{array}{l}\text { Commercial LWR fuel } \\
\text { reprocessing }\end{array}$ & $2 \mathrm{tHM} / \mathrm{d}$ & Target: 1995 \\
\hline & $\begin{array}{l}\text { FBR fuel repro- } \\
\text { cessing test } \\
\text { facility }\end{array}$ & $\begin{array}{l}\text { Develop FBR fuel repro- } \\
\text { cessing technology }\end{array}$ & $120 \mathrm{kgHM} / \mathrm{d}$ & Target: \\
\hline Pakistan & Chashma & Pu production & $300 \mathrm{kgHM} / \mathrm{d}$ & -- \\
\hline \multirow[t]{2}{*}{ USSR } & Industrial plant & Reprocess military fuels & -- & $1973-?$ \\
\hline & $\begin{array}{l}\text { Khlopin pilot } \\
\text { plant (Leningrad) }\end{array}$ & $\begin{array}{l}\text { Process development - } \\
\text { LWR \& FBR fuels }\end{array}$ & -- & \\
\hline \multirow[t]{5}{*}{ UK } & Butex (Sellafield) & $\begin{array}{l}\text { Pu production for } \\
\text { defense fuels; new } \\
\text { headend for oxide } \\
\text { fuels installed in } \\
1968\end{array}$ & $\begin{array}{l}\text { Oxide headend - } \\
1.5 \mathrm{tHM} / \mathrm{d}\end{array}$ & $\begin{array}{l}1952-1964 \\
1969-1973\end{array}$ \\
\hline & Magnox (Sellafield) & $\begin{array}{l}\text { Reprocess civilian and } \\
\text { military U metal (GCR) } \\
\text { fuels; take feed from } \\
\text { Butex oxide plant }\end{array}$ & $5-7 \mathrm{tHM} / \mathrm{d}$ & 1964-present \\
\hline & Thorp (Sellafield) & $\begin{array}{l}\text { Reprocess civilian and } \\
\text { foreign oxide fuels }\end{array}$ & $3 \mathrm{tHM} / \mathrm{d}$ & Target: \\
\hline & $\begin{array}{l}\text { DFR reprocessing } \\
\text { plant (Dounreay) }\end{array}$ & $\begin{array}{l}\text { Demonstrate FBR fuel } \\
\text { reprocessing technology }\end{array}$ & -- & $\begin{array}{l}\text { 1959-1975 } \\
\text { (Converted to } \\
\text { PFR) }\end{array}$ \\
\hline & $\begin{array}{l}\text { PFR reprocessing } \\
\text { plant (Dounreay) }\end{array}$ & $\begin{array}{l}\text { Demonstrate FBR fuel } \\
\text { reprocessing technology }\end{array}$ & $20 \mathrm{kgHM} / \mathrm{d}$ & 1980-present \\
\hline USA & West Valley (NFS) & $\begin{array}{l}\text { Civilian fuel repro- } \\
\text { cessing }\end{array}$ & $1-1.5 \mathrm{tHM} / \mathrm{d}$ & $\begin{array}{l}\text { 1966-1972 } \\
\text { (Decommissioned) }\end{array}$ \\
\hline
\end{tabular}


TABLE 1. (contd)

\begin{tabular}{|c|c|c|c|c|}
\hline Country & Facility & Mission & $\begin{array}{l}\text { Design } \\
\text { Capacity }\end{array}$ & Operational \\
\hline \multirow[t]{11}{*}{ USA (contd) } & Barnwell (BNFP) & $\begin{array}{l}\text { Civilian fuel repro- } \\
\text { cessing }\end{array}$ & $5 \mathrm{tHM} / \mathrm{d}$ & $\begin{array}{l}\text { Target: } 1974 \\
\text { (Decommi ssioned) }\end{array}$ \\
\hline & Midwest (MFRP) & $\begin{array}{l}\text { Civilian fuel repro- } \\
\text { cessing }\end{array}$ & $1-1.5 \mathrm{tHM} / \mathrm{d}$ & $\begin{array}{l}\text { Target: } 1972 \\
\text { (Decommissioned) }\end{array}$ \\
\hline & Idaho (ICPP) & $\begin{array}{l}\text { Reprocessing of test } \\
\text { reactor and US naval } \\
\text { fuel }\end{array}$ & -- & 1953-present \\
\hline & Savannah River/F & $\begin{array}{l}\text { Defense fuel reprocess- } \\
\text { ing }\end{array}$ & -- & 1955-present \\
\hline & Savannah River/H & $\begin{array}{l}\text { Defense fuel reprocess- } \\
\text { ing; production of spe- } \\
\text { cial isotopes (e.g., } \\
238 \mathrm{Pu})\end{array}$ & -- & 1955-present \\
\hline & Hanford/B & $\begin{array}{l}\text { Defense fuel reprocess- } \\
\text { ing and waste processing }\end{array}$ & -- & $1945-1952$ \\
\hline & Hanford/T & $\begin{array}{l}\text { Defense fuel reprocess- } \\
\text { ing }\end{array}$ & -- & $1944-1956$ \\
\hline & Hanford/U & $\begin{array}{l}\text { Recover } U \text { from } B \& T \text { Plant } \\
\text { wastes }\end{array}$ & -- & $1952-1958$ \\
\hline & Hanford/Redox & $\begin{array}{l}\text { Defense fuel reprocess- } \\
\text { ing }\end{array}$ & -- & $1951-1967$ \\
\hline & Hanford/Purex & $\begin{array}{l}\text { Defense fuel reprocess- } \\
\text { ing }\end{array}$ & -- & $\begin{array}{l}\text { 1955-1972 } \\
\text { 1983-present }\end{array}$ \\
\hline & EBR-II (Idaho) & $\begin{array}{l}\text { Demonstrate pyrochemical } \\
\text { reprocessing }\end{array}$ & -- & $\begin{array}{l}\text { 1966- } \\
\text { (Shutdown) }\end{array}$ \\
\hline
\end{tabular}

(a) -- indicates information not available. 
world inventory of unreprocessed metal power fuels should not become very large. 0xide fuels, on the other hand, are commonly clad in a zirconium alloy or, in a few cases, stainless steel; they can be stored safely for long periods; and reprocessing capacity for this class of fuel is building very slowly. Total arisings of oxide fuels by the year 2000 are estimated at over 200,000 tHM, with total annual arisings at that time of about 17,000 tHM. Western world annual oxide fuel arisings in the year 2000 are estimated at about 13,000 tHM, compared with a projected oxide fuel reprocessing capacity (excluding the U.S.A.) of under 6000 tHM.

The typical reprocessing plant receives the fuel, disassembles and dissolves it, extracts and purifies plutonium and uranium, and treats waste. The fuel disassembly and dissolution system differs for various fuels. Metallic fuels are dissolved completely, except when mechanical decladding can be done. The oxide fuels, becoming commonplace with the growing use of light water reactors, are chopped mechanically and the uranium oxide dissolved in nitric acid. Liquid-liquid extraction with tributyl phosphate in kerosene (PUREX) is almost universally used to extract and purify uranium and plutonium in the dissolver solution.

Design of reprocessing plants for maintenance is evolving away from the extreme represented by the "hands on" direct maintenance Eurochemic plant toward the totally remote "canyon" concept represented by the Savannah River and Hanford plants but making more use of manipulators. The proposed WA-350 plant being designed in the FRG represents the most advanced design to date. Pulse columns and mixer settlers are standard equipment in extraction systems, but use of centrifugal contactors is increasing.

Corrosion in the highly-acidic liquid systems appears to be a predominant cause of failures, resulting in extended plant shutdowns. Dissolvers and evaporators are particularly susceptible to this type of failure.

Development efforts are being concentrated on minimizing the use of chemicals (to reduce waste production), improving remote handling (to reduce personnel exposure and downtime for maintenance), and advanced waste treatment processes (fixation, techniques and recovery of iodine, krypton-85, and carbon-14). 
The designs of plants for reprocessing LWR oxide fuels and breeder mixedoxide fuels are similar. The latter type of plant is smaller because of the higher enrichment and must account for the normally higher burnup with greater accumulations of insoluble residues in the dissolver. The latter type of plant must consider sodium handling also. Both LWR and breeder fuels can generally be reprocessed in the same plant, however. 


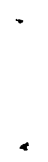




\section{INTRODUCTION}

The nuclear industry includes numerous activities, all directed at producing and using radioactive materials for power generation, weapons production, or industrial/institutional uses. The major operational steps of the nuclear industry are:

- Mining and milling of uranium and thorium ores

- Conversion to $\mathrm{UF}_{6}$

- Enrichment of the fissionable isotope

- Fabrication of nuclear fuels

- Irradiation in reactors

- Spent fuel storage

- Transportation

- Reprocessing to recover fissionable plutonium, uranium, and selected by-products

- Treatment and disposal of radioactive wastes.

Some of these steps making up the nuclear fuel cycle may or may not be used, depending upon the reactor type and the end objective. Reprocessing is used primarily to recover fissionable plutonium for recycle in power-generating reactors or for production of weapons. A decision by any country to reprocess spent nuclear fuels is driven, then, by their defense policy or by a desire to replace fissionable uranium (a natural resource) with fissionable plutonium, which theoretically can allow the country to become independent of external energy supplies.

International politics also influence a decision on nuclear fuel reprocessing.(1) The International Atomic Energy Agency (IAEA), now with 106 member states, was established in 1957 to promote the contribution of atomic energy toward peaceful purposes but in no way to further any military purposes. In 1968, the Treaty on the Non-Proliferation of Nuclear Weapons (NPT) gave the IAEA the task of verifying that no diversion of fissionable materials from 
peaceful uses to nuclear weapons occurs. Because of the widespread concern over proliferation, transfer of technology closely related to the weapons material production is closely controlled to prevent its transfer to countries not agreeing to be subject to IAEA safeguards. Nuclear fuel reprocessing, in which the fissionable plutonium is recovered from spent nuclear fuel, is an example of such technology.

As is evident from the open literature, the principles of reprocessing are well known. However, the application of these principles to actual practice is a complicated and expensive operation, and a non-proliferation objective is to restrict the flow of hands-on knowledge and actual equipment as well as nuclear materials. The spent fuel storage and waste treatment activities associated with reprocessing, however, are not peculiar or essential to plutonium recovery operations and these topics are thus not subject to tight constraints on technology transfer to other countries.

Current projections of nuclear power capacity $(2,3)$ indicate that 34 nations will have commercial nuclear power stations operating by the year 2000. Fifteen are known to have spent fuel reprocessing programs, ranging from hot cell R\&D to the operation of industrial plants, and two other countries have planned or conducted reprocessing R\&D programs in the past. Six countries are known to have reprocessing plants devoted to weapons material production.

The type of reprocessing program undertaken in a country is influenced also by the reactor type used. Nine distinct types of nuclear power reactors are either in commercial use or in the demonstration stage. In a discussion of the fuel cycle, it is convenient to divide them into four major classes, according to fuel type:

1. Uranium metal or metal alloys

- Gas-Cooled Reactor, GCR (built in significant numbers by the United Kingdom (UK) and France and tried on a one-time bas is by several other countries).

- Light Water-Cooled, Graphite-Moderated Reactor, LGR (one operating in the USA, many in the USSR).

- Material Test Reactors (many located around the world). 
2. Uranium dioxide $\left(\mathrm{UO}_{2}\right)$

- Light Water Reactor, LWR (the most popular reactor type, in use in large numbers and in many nations). LWRs come in two varieties-Pressurized Water Reactors (PWRs) and Boiling Water Reactors (BWRs)

- Heavy Water Reactor, HWR (heavily exploited by Canada, in use in several other countries)

- Advanced Gas-Cooled Reactor, AGR (second-generation gas-cooled reactor, in use in the UK)

- A second-generation LGR (USSR).

3. Mixed oxide (MOX, $\mathrm{UO}_{2} / \mathrm{PuO}_{2}$ )

- Fast Breeder Reactor, FBR (demonstration stage in several countries)

- MOX fuels have been used in LWR demonstrations and may be used more extensively in LWRs and HWRs in the future.

4. Uranium and thorium oxides and carbides, clad in graphite

- High-Temperature Gas-Cooled Reactor, HTGR (demonstration stage).

There are, of course, many variations in fuel and cladding composition with in each major class of fuel. Examples for each reactor type are given in Table 2, which also identifies reactor moderators and coolants.

The extent to which reprocessing is applied is also dependent upon a country's fuel cycle planning. In some cases, the fuel is regarded as a waste and is to be disposed of directly. In other cases, it is taken to a reprocessing facility (either domestic or foreign), where the plutonium, unburned uranium and selected by-products can be recovered. In many cases, the spent fuel is simply being stored until final decision is made between the once-through and reprocessing schemes. Choice of fuel cycle system is driven by reactor type and by the predictions of nuclear planners concerning the availability and cost of uranium, the future of the nuclear industry and of the industrial application of breeder reactor technology. With the current reduced demand for electricity and nuclear power, recycle of plutonium has become less attractive. Although demonstrated in light-water and breeder reactors, no substantial recycle of plutonium appears likely for decades. (4) 
TABLE 2. Reactor Parameters--Selected Power Stations (2)

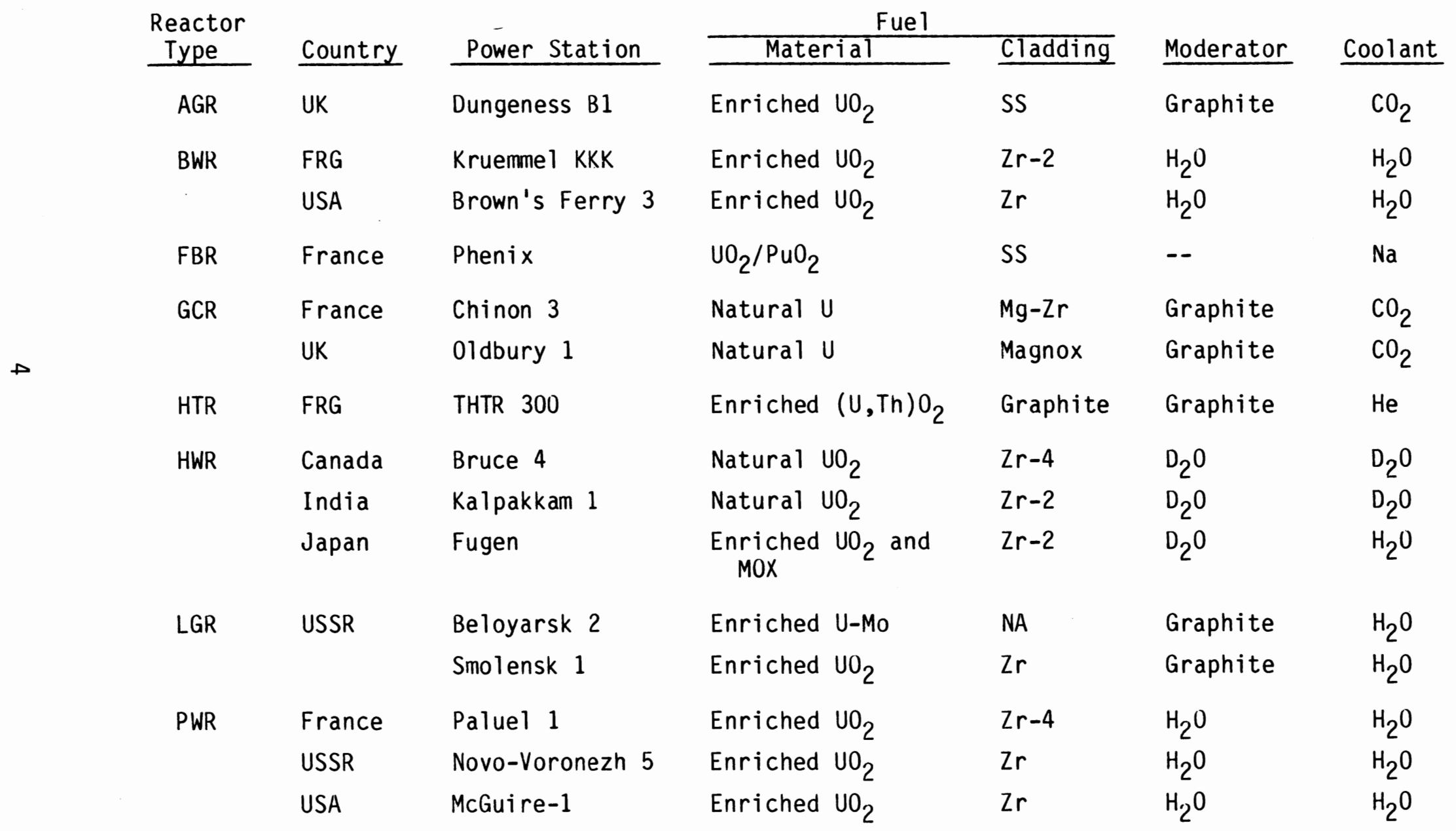


These choices lead to the identification of three different types of fuel cycle:

1. In the once-through scheme, the spent fuel is kept in an interim storage facility until it can be disposed of.

2. In thermal reactor recycle, the spent fuel is reprocessed (subjected to a chemical process in which uranium, plutonium and perhaps one or more by-products are recovered). Both the uranium and the plutonium can then be incorporated in new fuel elements for recycle to a thermal reactor.

3. In fast breeder reactor recycle, the spent fuel is reprocessed and the uranium and plutonium recycled to fast breeder reactors. FBRs have a central core of $\mathrm{PuO}_{2} / \mathrm{UO}_{2}$ fuel surrounded by a blanket of depleted uranium, allowing the recycle of recovered uranium without enrichment.

A schematic of these cycles is represented in Figure 1. Part A depicts the front end of a once-through thermal fuel cycle: uranium ore is mined, converted to yellowcake, enriched in the ${ }^{235} \mathrm{U}$ isotope, fabricated into fuel elements and irradiated in a thermal reactor. Here the back end consists of spent fuel storage followed by disposal. B depicts a thermal reactor recycle back end in which recovered uranium is sent back to A for enrichment, and both uranium and plutonium are incorporated in $\mathrm{PuO}_{2} / \mathrm{UO}_{2}$ fuel for recycle to a thermal reactor. C shows the fast breeder recycle concept, in which plutonium and depleted uranium fuel a breeder reactor.

The tonnage of spent fuel discharged from a reactor or reactor complex in a year's time is a function mainly of the reactor power level, the fuel burnup and the reactor operating efficiency. Estimated annual discharge rates (annual arisings) for the reactor types listed in Table 2 are shown in Table 3, along with a few other spent fuel parameters--the weight of a typical fuel element, expected burnup level, and estimated annual spent fuel arisings per GWe of installed capacity. 


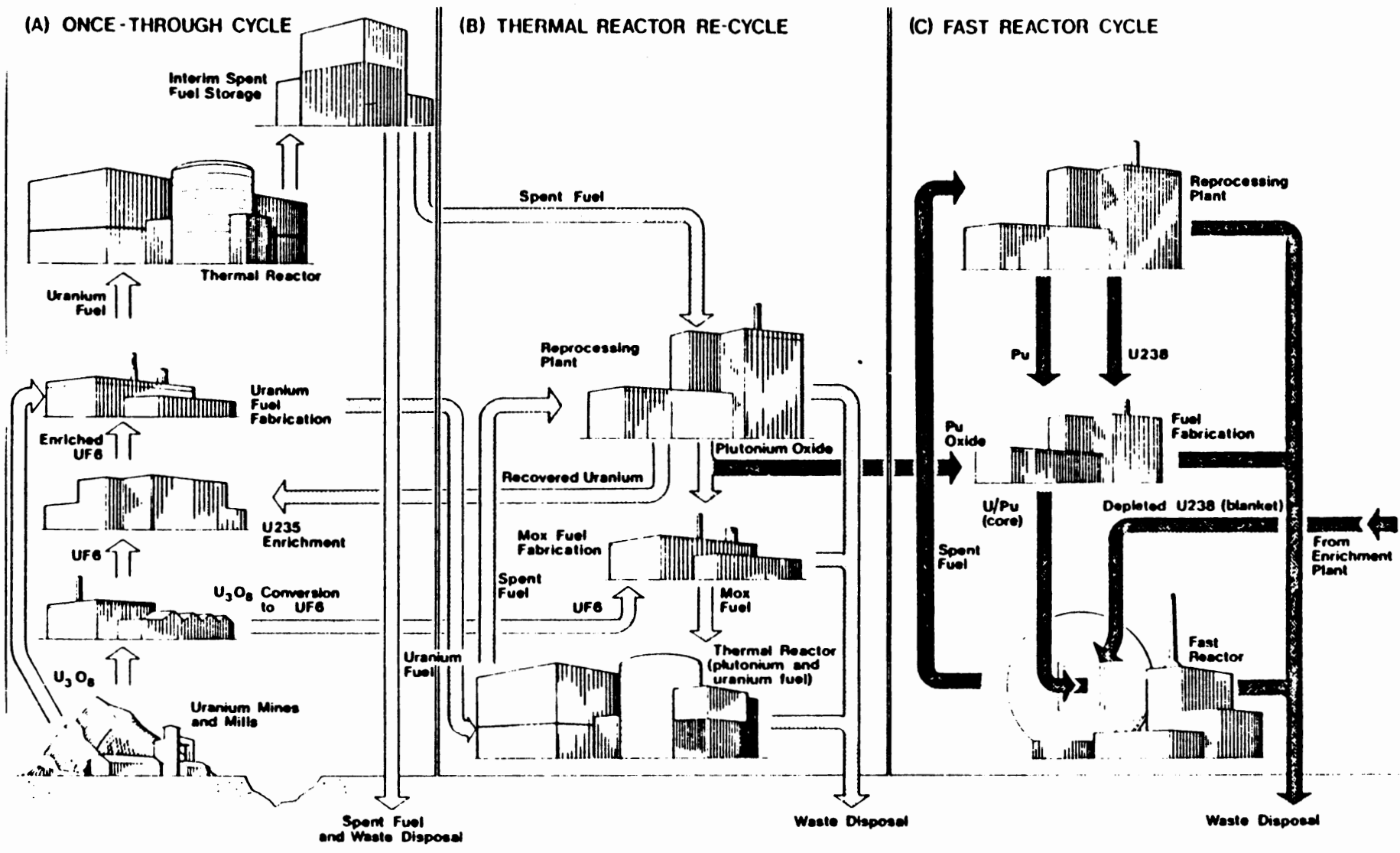

FIGURE 1. Nuclear Fuel Cycles (5) 
TABLE 3. Spent Fuel Parameters--Selected Power Stations

\begin{tabular}{|c|c|c|c|c|c|c|}
\hline $\begin{array}{c}\text { Reactor } \\
\text { Type }\end{array}$ & Power Station & \multicolumn{2}{|c|}{ Reactor Size } & $\begin{array}{c}\text { Weight HM } \\
\text { per Fuel } \\
\text { Element, } \mathrm{kg}(2)\end{array}$ & $\begin{array}{c}\text { Expected } \\
\text { Burnup } \\
\text { MWd/tHM }\end{array}$ & $\begin{array}{c}\text { Calculated } \\
\text { Spent Fuel } \\
\text { Discharge per } \\
\text { GWe•yr, tHM } \\
\end{array}$ \\
\hline AGR & Dungeness $B 1$ & 600 & 1,480 & 42.8 & 18,000 & 49 \\
\hline BWR & Kruemmel KKK & 1,260 & 3,690 & 186 & 27,500 & 39 \\
\hline FBR & Phenix & 233 & 563 & 42 & 100,000 & 8.2 \\
\hline \multirow[t]{2}{*}{ GCR } & Chinon 3 & 480 & 1,560 & 9.4 & 3,500 & 338 \\
\hline & 01 dbury 1 & 416 & 1,500 & 11 & 5,000 & 267 \\
\hline HTR & THTR 300 & 296 & 760 & & 109,000 & 8.6 \\
\hline \multirow[t]{3}{*}{ HWR } & Bruce 4 & 740 & 2,519 & 17.3 & 8,167 & 152 \\
\hline & Kalpakkam 1 & 220 & 790 & 15.3 & 6,700 & 195 \\
\hline & Fugen & 148 & 557 & 152 & 17,000 & 81 \\
\hline \multirow[t]{2}{*}{ LGR } & Beloyarsk 2 & 200 & 530 & NA & $12-20,000$ & $48-80$ \\
\hline & Smolensk 1 & 1,000 & 3,200 & NA & 18,500 & 63 \\
\hline \multirow[t]{3}{*}{ PWR } & Paluel 1 & 1,290 & 3,817 & 538 & 33,000 & 33 \\
\hline & Novo-Voronezh 3 & 440 & 1,375 & 120 & $28-30,000$ & 38 \\
\hline & Novo-Voronezh 5 & 1,000 & 3,000 & 437 & $26-40,000$ & $27-42$ \\
\hline
\end{tabular}

(a) Spent fuel discharge rates were calculated from expected burnup and, where available, published reactor efficiency data. Estimated reactor efficiencies were used when published data were not available. 
Table 4 provides a country-by-country estimate of installed nuclear power capacities, annual spent fuel arisings rates and cumulative spent fuel arisings as of the year 2000. The projections of foreign spent fuel arisings in Table 4 and in later sections of the report were calculated by PNL, using data in References 6 and 7 and current forecasts of total nuclear power capacity in References 2 and 8, while US data were taken from Reference 9. 
TABLE 4. Nuclear Power Projections for the Year 2000

\begin{tabular}{|c|c|c|c|c|}
\hline \multirow[b]{2}{*}{ Country } & \multirow[b]{2}{*}{ Reactor Type (a) } & \multirow{2}{*}{$\begin{array}{l}\text { Capacity, (a) } \\
\text { GWe } \\
\end{array}$} & \multicolumn{2}{|c|}{$\begin{array}{c}\text { Spent Fuel } \\
\text { Arisings, } t H M(b) \\
\end{array}$} \\
\hline & & & Annual & Cumulative \\
\hline Argentina & HWR & 3.7 & 650 & 5,800 \\
\hline Belgium & PWR & 8.0 & 220 & 3,000 \\
\hline Brazil & PWR & 4.4 & 120 & 1,000 \\
\hline Bulgaria & PWR & 7.8 & 200 & 2,500 \\
\hline Canada & HWR & 14.9 & 2,400 & 38,000 \\
\hline China & PWR & 10 & 270 & 1,300 \\
\hline Cuba & PWR & 1.8 & 50 & 420 \\
\hline Czechoslovakia & PWR & $11-14(10)$ & 350 & 3,800 \\
\hline Egypt & PWR & 2.7 & 70 & 360 \\
\hline Finland & LWR & 3.2 & 100 & 1,400 \\
\hline France & $\begin{array}{l}\text { GCR } \\
\text { PWR } \\
\text { FBR }\end{array}$ & $\begin{array}{l}60^{--} \\
1.5\end{array}$ & 1,500 & $\begin{array}{l}15,000 \\
22,000\end{array}$ \\
\hline Germany-East & PWR & $9(11)$ & 270 & 2,100 \\
\hline Germany-West & $\begin{array}{l}\text { LWR } \\
\text { HTGR } \\
\text { FBR }\end{array}$ & $\begin{array}{l}28 \\
0.3 \\
0.3\end{array}$ & 700 & 11,000 \\
\hline Hungary (1990) & PWR & $4.8(12)$ & 150 & 1,400 \\
\hline India & $\begin{array}{l}\text { BWR } \\
\text { HWR }\end{array}$ & $\begin{array}{l}0.4 \\
4.0\end{array}$ & $\begin{array}{r}18 \\
560\end{array}$ & $\begin{array}{r}600 \\
4,400\end{array}$ \\
\hline Is rael & LWR & 4.6 & 110 & 400 \\
\hline Italy & $\begin{array}{l}\text { GCR } \\
\text { LWR }\end{array}$ & $\begin{array}{l}-- \\
6.7\end{array}$ & 240 & $\begin{array}{l}1,700 \\
2,000\end{array}$ \\
\hline Japan & $\begin{array}{l}\text { GCR } \\
\text { LWR } \\
\text { HWR } \\
\text { FBR }\end{array}$ & $\begin{array}{l}-- \\
50 \\
0.15 \\
0.28\end{array}$ & 1,400 & $\begin{array}{r}1,500 \\
20,000\end{array}$ \\
\hline Korea (South) & $\begin{array}{l}\text { PWR } \\
\text { HWR }\end{array}$ & $\begin{array}{r}10.5 \\
0.6\end{array}$ & $\begin{array}{r}310 \\
70\end{array}$ & $\begin{array}{l}3,200 \\
1,200\end{array}$ \\
\hline Mexico & PWR & 1.3 & 40 & 500 \\
\hline Netherlands & LWR & 0.5 & 16 & 420 \\
\hline Pakistan & HWR & 0.13 & 12 & 290 \\
\hline & LWR & 1.0 & 30 & 150 \\
\hline
\end{tabular}


TABLE 4. (contd)

\begin{tabular}{|c|c|c|c|c|}
\hline \multirow[b]{2}{*}{ Country } & \multirow[b]{2}{*}{ Reactor Type (a) } & \multirow{2}{*}{$\begin{array}{c}\text { Capacity, (a) } \\
\text { GWe }\end{array}$} & \multicolumn{2}{|c|}{$\begin{array}{l}\text { Spent Fuel } \\
\text { Arisings, tHM (b) }\end{array}$} \\
\hline & & & Annual & Cumulative \\
\hline $\begin{array}{l}\text { Philippines } \\
\text { Poland } \\
\text { Romania }\end{array}$ & $\begin{array}{l}\text { PWR } \\
\text { PWR } \\
\text { PWR } \\
\text { HWR }\end{array}$ & $\begin{array}{l}1.2 \\
5.9 \\
0.44 \\
6.6(13)\end{array}$ & $\begin{array}{r}32 \\
175 \\
13 \\
750\end{array}$ & $\begin{array}{r}270 \\
1,000 \\
220 \\
8,000\end{array}$ \\
\hline South Africa & PWR & 3.8 & 115 & 1,200 \\
\hline Spain & $\begin{array}{l}\text { GCR } \\
\text { LWR }\end{array}$ & $\begin{array}{l}0.48 \\
9.7\end{array}$ & $\begin{array}{r}60 \\
260\end{array}$ & $\begin{array}{l}1,700 \\
3,400\end{array}$ \\
\hline Sweden & LWR & 9.4 & 260 & 5,000 \\
\hline Switzerland & LWR & 3.4 & 140 & 2,000 \\
\hline Taiwan & LWR & 8.7 & 260 & 2,600 \\
\hline UK & $\begin{array}{l}\text { GCR } \\
\text { AGR } \\
\text { PWR } \\
\text { FBR }\end{array}$ & $\begin{array}{l}-- \\
8.2 \\
5.1 \\
0.25\end{array}$ & $\begin{array}{r}-- \\
270 \\
140 \\
--\end{array}$ & $\begin{array}{r}35,000 \\
4,700 \\
630 \\
--\end{array}$ \\
\hline$U S A(c)$ & LWR & 117 & 3,600 & 58,000 \\
\hline USSR (1990) & $\begin{array}{l}\text { LGR (Metal fuels) } \\
\text { LGR (Oxide fuels) } \\
\text { PWR } \\
\text { FBR }\end{array}$ & $\begin{array}{r}0.9 \\
17.0 \\
23.9 \\
0.8\end{array}$ & $\begin{array}{r}50 \\
720 \\
640 \\
--\end{array}$ & $\begin{array}{r}1,500 \\
7,400 \\
3,700 \\
--\end{array}$ \\
\hline Yugoslavia & PWR & 2.6 & 70 & 420 \\
\hline
\end{tabular}

(a) Unless otherwise indicated, nuclear power forecasts were obtained from References 2 and 8.

(b) Projections of foreign spent fuel arisings were based on data in References 6 and 7, modified by PNL to fit current forecasts of nuclear power capacity.

(c) U.S.A. data were taken from Reference 9. 


\section{NATIONAL NUCLEAR PROGRAMS INVOLVING REPROCESSING}

The nuclear activities involving fuel reprocessing under way in various countries are described in the following sections. For the reader needing more familiarity with reprocessing technology, Appendix A describes a typical nuclear fuel reprocessing plant. Additional data on reprocessing programs discussed in the national sections are summarized in tabular form in Appendix B.

ARGENTINA (14-19)

Argentine authorities place a high priority on developing a selfsufficient nuclear power industry based on the Canadian (CANDU) version of the $H W R$, which is fueled with natural uranium and moderated with $D_{2} 0$. They also intend to become a supplier of nuclear equipment, materials and services to Latin American countries. All nuclear power plants are owned and operated by the government, through the National Atomic Energy Commission.

Nuclear Power Projections

Capacity, HWR (GWe) (2)

$$
\begin{array}{lllll}
1980 & \frac{1985}{0.3} & \frac{1990}{0.9} & \frac{1995}{1.6} & \frac{2000}{2.3}
\end{array}
$$

Spent Fuel Arisings (tHM) (a)

Annual

Cumulative

$$
\text { (a) }
$$

940

280

400

650

416

\section{Fuel Cycle Policy}

Argentina has operated a 335-MWe PHWR since 1974 and brought a 600 MWe unit on-line in 1983. A 700 MWe PHWR unit is under construction; four additional units are planned. HWR fuel elements have been produced in a locally designed fabrication plant since 1982; Zircaloy ingots have been produced locally, and development of the manufacturing process for Zircaloy tubing has been completed; mixed oxide $\left(\mathrm{PuO}_{2} / \mathrm{UO}_{2}\right)$ fuel elements are under development, and

(a) Data obtained from Reference 6, modified by PNL to fit current nuclear power forecasts. 
the country is considering the possibility of developing the $\mathrm{ThO}_{2}-{ }^{23} \mathrm{U}$ fuel cycle. A heavy water plant is under construction and the first module of a gaseous diffusion uranium enrichment plant began operation in 1983. Output is expected to reach 300 grams/day of $20 \%$ enriched uranium by late 1985. Reactor pools are sized to accommodate discharged fuel until the end of the 1990s, and field and design work are progressing for a geologic HLW repository at the Sierra del Medio.(a)

\section{Reprocessing Activities}

Argentina operated a small experimental reprocessing facility from 1967 to the early 1970s, and a new pilot reprocessing facility is under construction at the Ezeiza Atomic Centre, $40 \mathrm{~km}$ from Buenos Aires (owned and operated by the Comisión National de Energía Atomica) for oxide and MTR-type fuels. This $20 \mathrm{~kg} /$ day $\mathrm{plant}$ is scheduled to be ready for radioactive operation in 1987 .

The plant is of conventional design. Fuel is disassembled, chopped, and dissolved in a remote handling operation. Two cycles of mixer-settlers are used to extract the fissile material. Uranium is purified in a third mixersettler step; plutonium is recovered by ion exchange. High-level wastes are to be vitrified with a pot-type process while intermediate-level wastes are to be fixed in polymer concrete. Other than the head end operations, semi-remote techniques are used in the processing. Basic engineering design studies have begun on a larger plant $(\sim 160 \mathrm{~kg} /$ day $)$.

$\underline{\operatorname{BELGIUM}}(20-26)$

Belgium has five operating PWRs and two under construction. When all are operating in late 1984 or 1985, nuclear power will account for about 60\% of the country's total electric generating capacity.(b) The utilities hope to build additional nuclear stations, and the country is working towards FBR capability through participation in the Kalkar SNR-300 project in West Germany.

(a) Ornstein, R., Manager of CNEA's International Affairs Division, Buenos Aires, Argentina, Letter to P. J. Mellinger, Pacific Northwest Laboratory, August 23, 1983.

(b) Detilleux, E., Manager of Eurochemic, Letter to P. J. Mellinger, PNL, August 18, 1983. 
The national government supports an active nuclear R\&D program, which includes fuel reprocessing and waste management activities, at the Belgian nuclear research center (SCK/CEN) at Mol. Companies or agencies involved in the country's commercial fuel cycle/waste management activities include Belgonucléaire (MOX fuel fabrication and waste treatment), NIRAS/ONDRAF (the national waste management company), and SYNATOM (a company formed by the utilities and the government to take care of fuel cycle needs). A consortium (SYBELPRO), consisting of Synatom of Belgium (60\%), Cogema of France (20\%), and DWK of West Germany $(20 \%)$ is studying the possibility of reopening the Eurochemic reprocessing facility.

Nuclear Power Projections

Capacity, PWR (GWe) (2)

Spent Fuel Arisings (tHM) (a)

Annual

Cumulative

$\begin{array}{lllll}1980 & \frac{1985}{1.7} & \frac{1990}{5.4} & \frac{1995}{5.4} & \frac{2000}{6.7}\end{array}$

150

150

180 220

$1,300 \quad 2,100$

\section{Fuel Cycle Policy}

The country has an extensive fuel cycle program which embraces takeover and operation of the Eurochemic fuel reprocessing plant and waste treatment facilities at Mol-Dessel, continued operation of a MOX fuel fabrication plant and CEN/SCK waste treatment facilities, and construction of a geologic repository in a plastic clay formation.

The Belgian utilities have contracts in place with Cogema (France) for reprocessing $500 \mathrm{tU}$ of their spent fuel, and are considering recycling plutonium to their LWRs.

Reprocessing Activities

The Belgian government has taken over ownership of the Eurochemic reprocessing plant, located on a tract of land adjacent to the Belgian Nuclear

(a) Data obtained from Reference 7 , modified by PNL to reflect current power station construction schedules. 
Research Center at Mol, and is proceeding with plans to refurbish and operate the facility. The plant had been built under the auspices of 13 European countries for two major purposes: to provide an opportunity for their technical personnel to gain operating experience and to demonstrate the reprocessing of a variety of fuel types. Construction started in 1960 and cost $\$ 30$ million U.S. Radioactive operations started in 1966 , and the plant operated until it was shut down in 1974 because the major participants were involved in their own reprocessing activities.

The Eurochemic facility was designed for direct maintenance. It was also designed to process a variety of fuels from research and power reactors: 1owenrichment or high-enrichment uranium; uranium metal, oxide, or alloy core materials; and aluminum, magnesium, Magnox, stainless steel or Zircaloy cladding. Design capacities were $350 \mathrm{~kg} \mathrm{U} /$ day for natural and $10 \mathrm{w}$-enriched uranium $(<1.6 \% 235 \mathrm{U}), 250 \mathrm{~kg} /$ day for uranium of $1.6-5 \% 235 \mathrm{U}$, and 5 to $10 \mathrm{~kg} \mathrm{U} /$ day for MTR types of fuel. The process used chemical decladding; a two-cycle Purex flowsheet for low-enrichment fuels and a three-cycle flowsheet for highly-enriched fuels; and pulse columns for all cycles except the third, which was equipped with mixer-settlers. Concentrated high-level waste is stored in cooled stainless-steel tanks.

By 1974, the plant had processed about $90 \mathrm{t}$ of natural or slightly enriched uranium from research reactors, $100 \mathrm{t}$ of LWR fuels (maximum burnup = $21,000 \mathrm{MWd} / \mathrm{tU}$ ) and $30 \mathrm{t}$ of highly enriched uranium fuels from high-flux reactors. This resulted in the recovery of $680 \mathrm{~kg}$ plutonium (as $\mathrm{PuO}_{2}$ ) and the production of about $870 \mathrm{~m}^{3}$ of $\mathrm{high-level}$ and $2000 \mathrm{~m}^{3}$ of medium-level aqueous waste solutions.

Since its decommissioning in 1974:

1. The plant has been decontaminated sufficiently to allow access for renovation. Process equipment was flushed thoroughly with nonaggressive decontaminating solutions; hot spots on external surfaces were treated with high-pressure water sprays; and selected items of equipment, including some of the head-end equipment and the $\mathrm{PuO}_{2}$ facility, were removed. 
2. The Eurochemic company has installed several facilities for treatment and storage of low- and intermediate-level wastes from reprocessing: Eurobitum, a $650 \mathrm{~m}^{3} / \mathrm{yr}$ bituminization $\mathrm{plant;}$ Eurostorage, for storage of conditioned wastes; and Eurowatt, a pilot facility for treating waste PUREX solvent.

In 1978, the Belgian government and the Eurochemic partners agreed to the transfer of all Eurochemic facilities to Belgium. This transfer occurred in January 1980, but Belgium could not take over full responsibility in 1981 as foreseen, since the decision to resume reprocessing was still pending in Parliament. Due to this situation, the Eurochemic board of directors granted Belgium an 18-to-24-month reprieve in which to decide whether or not to take over the Eurochemic plant and resume reprocessing at Mol-Dessel.

The Parliamentary approval was obtained in April 1983. Immediately, the Belgian Nuclear Fuel Cycle Company, SYNATOM (50\% state, 50\% private utilities), set up a Working Party to finalize the studies on refurbishing that had been performed unofficially for several years. This Working Party, named "SYBELPRO," asSociates the Belgian SYNATOM (60\%), the French Cogema (20\%) and the German Company for Reprocessing, DWK (20\%). The objective of SYBELPRO is to submit to the authorities a Preliminary Safety Analysis Report (PSAR) and to establish a cost estimate in order to be able to make the decision to proceed before the end of the first half of 1984 . (a)

The plant will be adapted to the processing of standard and MOX LWR fuel elements, but may be used for Belgian, French and German nonstandard fuels, in return for French or German reprocessing of Belgian PWR fuels. A new head-end (chop-leach) will be installed with a daily throughput of up to $600 \mathrm{~kg}$ of heavy metal. Coprecipitation could be introduced at the back end, providing premixed plutonium and uranium oxides suitable for mixed-oxide fuel fabrication. Highlevel waste treatment facilities will be added. The cost of reopening the plant is currently estimated at about $\$ 340$ milion. Officials at Eurochemic say that the plant will have to be adapted to current needs, and should be fully operational by 1986 or 1987 . (a)

(a) Detilleux, E., Manager of Eurochemic, Letter to P. J. Mellinger, PNL, August 18, 1983. 
In support of the national interest in FBR technology, a pilot plant for studies of head-end and off-gas control in fuel reprocessing has been built at the research center at Mol. Known as HERMES (Head-End Research Facility on Mock-Up Engineering Scale), this hot-cell complex can handle 10-kg batches of LMFBR UO $2-\mathrm{PuO}_{2}$ fuel. Process components include:

- gas-tight pin chopper

- oxidation furnace and grinding devices

- critically safe dissolver

- off-gas treatment systems.

A HLW vitrification plant, based on the liquid-fed ceramic melter process, is being built by FRG interests in Eurochemic space at Mol. It will be used to process the PUREX-type HLW remaining from Eurochemic reprocessing of lowenriched fuels, and may be used for all the Eurochemic HLW. If the Eurochemic Plant is to be commissioned, a second vitrification plant (AVB) is to be built at Mol, modeled after the French AVM process. If built (as a joint BelgianEurochemic project), AVB is to serve as the HLW immobilization plant for a large part of the existing Eurochemic HLW inventory as well as for future reprocessing operations.

Belgian strategies for managing TRU-contaminated materials are based upon the following principles:

- drastic reduction in the primary waste volume

- maximum recovery and reuse of plutonium

- use of high-temperature slagging incineration to condition wastes from which plutonium has not been removed.

Dissolver off-gas R\&D programs associated with the HERMES project include krypton, iodine and tritium recovery. A cryogenic unit was operated on MOX fuels in the early 1980s with apparently excellent results for the capture of krypton. From these results, it appears that an overall DF of 100 may be quite attainable. Overall iodine DFs up to 150,000 were experimentally determined. Program objectives are to achieve a DF of $10^{4}$ for iodine and a DF of 60 for krypton. 
$\underline{\operatorname{BRAZIL}}(16,17,27,28)$

The government is promoting an ambitious program to develop a complete, government-owned nuclear industry, based upon PWRs and technology transfer from the FRG and other nations.

Major Brazilian facilities include the Center for the Development of Nuclear Technology at Belo Horizonte and a fuel cycle complex at Resende in the state of Rio de Janeiro.

Nuclear Power Projections

Capacity, PWR (GWe) (2)

Spent Fuel Arisings (tHM) $(a)$

Annual

Cumulative

$\begin{array}{llllll}1980 & \frac{1985}{--} & \frac{1990}{0} & \frac{1995}{1.9} & \frac{2000}{3.1} & 4.4\end{array}$

$\begin{array}{rrrrr}-- & 16 & 50 & 80 & 120 \\ -- & 32 & 180 & 500 & 1,000\end{array}$

\section{Fuel Cycle Policy}

The government is working to develop complete domestic fuel cycle capability through equipment and technology acquisition agreements with West Germany and other countries, in the following areas of technology: uranium mining, milling and enrichment; fuel fabrication; and reprocessing. Reprocessing Activities

Design for a proposed pilot fuel reprocessing plant was completed in 1981. Reports indicate that the pilot plant will be located in the Rio de Janeiro area, perhaps at Resende; that it will have a $10 \mathrm{~kg} / \mathrm{d}$ design capacity; and that it will be the fore-runner of a $300 \mathrm{t} / \mathrm{yr}$ industrial-scale facility. In January 1982, the construction schedule called for completion in 1986, but this is probably optimistic in view of Brazil's budgetary problems. Brazil secured an $\$ 85$ million loan for the facility from an FRG financial institution in February 1983.

(a) Data obtained from Reference 7 , modified by PNL to reflect current power station construction schedules. 
CANADA (29)

Canada has invested heavily in the development, domestic use and export of the CANDU (HWR, fueled with natural $U_{2}$ and moderated with $D_{2} O$ ) reactor system and its associated fuel cycle. Although CANDU fuel is discharged after relatively low burnup, Canada has sufficient uranium reserves to continue operating its reactors without fuel recycle well into the next century, and there has been little incentive as yet to reprocess spent fuels. However, a decision to recover plutonium is possible in the future, and Canada may turn to a Th-233U fuel cycle. Hence, a small reprocessing R\&D activity is carried on at Whiteshe11, and the "nuclear fuel waste" program is preparing to dispose of either CANDU $\mathrm{UO}_{2}$ fuels or reprocessing wastes in a crystalline rock repository.

Commercial nuclear power activities in Canada are handled primarily by two organizations: a government-owned corporation, Atomic Energy of Canada Limited (AECL), which manages and performs most of the country's nuclear research and development, and Ontario Hydro, the utility which owns and operates most of Canada's nuclear power reactors. Reprocessing R\&D is the responsibility of AECL's Whiteshell Nuclear Research Establishment.

Nuclear Power Projections

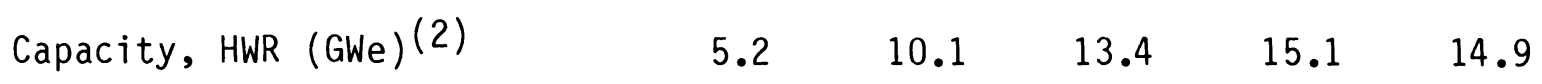

Spent Fuel Arisings (tHM) (a)

Annual

$830 \quad 1,040 \quad 1,600 \quad 2,400 \quad 2,400$

Cumulative

$3,650 \quad 8,800 \quad 18,000 \quad 28,000 \quad 38,000$

Reprocessing Activities

Canada has a small reprocessing R\&D activity at the Whiteshell Nuclear Research Establishment to reprocess $\mathrm{UO}_{2}$ fuels and to evaluate the use of the $\mathrm{ThO}_{2}{ }^{-233} \mathrm{U}$ fuel cycle. A $0.3-\mathrm{kg} / \mathrm{d}$ reprocessing apparatus was installed in

(a) Estimated from power projections. 
Whiteshell hot cells. Equipped with six banks of mini-mixer-settlers, the unit will be used for THOREX process studies. (a)

$\underline{\text { CHINA }}(16,17,30)$

Energy demand is rising rapidly in China, and planners do not believe that future requirements can be met through the country's coal and hydropower resources. Therefore, the government has embarked on a nuclear power program, starting with PWRs, and looks to breeders and fusion for the long-term. (b)

The nation has a well-developed, small-scale nuclear weapons program with facilities for uranium conversion and enrichment, fuel fabrication and reprocessing. Their reprocessing operations use the PUREX process.

Nuclear Power Projections

Capacity, PWR (GWe) $(8,30)$

Spent Fuel Arisings (tHM) $(c)$

Annual

Cumulative

$\frac{1985}{0.6} \quad \frac{1990}{0.6} \quad \frac{2000}{10}$

16

16

270

8

90

1,300

FRANCE $(31-47)$

France is aggressively developing domestic nuclear power and fuel cycle capability, marketing fuel cycle services, and exporting equipment, plants, and technology. At present, emphasis is being placed on expansion of fuel reprocessing capacity to satisfy domestic and foreign requirements, demonstration of the FBR fuel cycle, development of waste treatment and terminal waste storage technology, and construction of industrial waste treatment plants.

(a) Lisle, D., 1983, Technical Assistant to the Director, Waste Management Division, Whiteshell Nuclear Research Establishment Pinawa, Manitoba, letter to P. J. Mellinger, Pacific Northwest Laboratory, August 24.

(b) Yingzhong, L., 1983, Professor and Director, Institute of Nuclear Energy Technology, Beijing, China, letter to P. J. Mellinger, Pacific Northwest Laboratory, August 28.

(c) Estimated by PNL from nuclear capacity forecasts. 
The French Atomic Energy Commission (CEA) controls all nuclear R\&D, while its semi-autonomous subsidiary, COGEMA, handles all industrial fuel cycle activities. Waste disposal responsibility has been assigned to another CEA subsidiary, ANDRA. The CEA places responsibility for industrial fuel reprocessing on COGEMA and for research and development activities on its Chemical Division, which has its headquarters at Fontenay-aux-Roses Research Center and its facilities principally there and at Marcoule (VALRHO). The major reprocessing facilities are located at the Marcoule Centre and at La Hague. Nuclear Power Projections

\begin{tabular}{|c|c|c|c|c|c|}
\hline & 1980 & 1985 & 1990 & 1995 & 2000 \\
\hline \multicolumn{6}{|l|}{ Capacity (GWe) (2) } \\
\hline GCR & 2.2 & 2.2 & 2.2 & 1.9 & -- \\
\hline PWR & 9.9 & 32.2 & 47.2 & 54.1 & 60.0 \\
\hline FBR & 0.25 & 1.5 & 1.5 & 1.5 & 1.5 \\
\hline \multicolumn{6}{|l|}{ Spent Fuel Arisings (tHM)(a) } \\
\hline Annual, PWR & 250 & 800 & 1,200 & 1,300 & 1,500 \\
\hline \multicolumn{6}{|l|}{ Cumulative } \\
\hline GCR (metal fuels) & 5,600 & 8,000 & 10,000 & 13,000 & 15,000 \\
\hline PWR & 250 & 2,700 & 8,000 & 14,000 & 22,000 \\
\hline
\end{tabular}

Fuel Cycle Policy

French fuel cycle policy is to provide complete fuel cycle services for domestic and foreign customers. Activities include: uranium mining, milling and enrichment; fabrication of uranium metal, $\mathrm{UO}_{2}$ and $\mathrm{MOX}$ fuel; spent fuel reprocessing and plutonium recycle to FBRs; and HLW vitrification and disposal in a geologic repository. When the Socialist government came into power in 1981, the reprocessing policy was questioned and subjected to an in-depth review by a special committee. The resulting report, released in early 1983, gave a clean bill of health to the reprocessing plant at La Hague and endorsed

(a) PNL estimates based on data in Reference 7 and current forecasts of nuclear power capacity. 
reprocessing as the best approach to waste management. The Energy Minister then confirmed that construction of two new plants at La Hague was to proceed on schedule.

\section{Reprocessing Activities}

France has been reprocessing spent fuels since 1958, initially in UP1 at Marcoule, and since 1967 in UP2 at La Hague. Both were used initially for uranium metal fuels and were designed for mechanical cladding removal, a PUREX solvent extraction process, and contact maintenance. Irradiated fuel from both gas-cooled and light-water reactors is transported from the power stations in casks meeting international regulations. Both "wet" and "dry" casks are used at present, but it is planned to change essentially to dry transportation and unloading in the future. In 1976, a new chop-leach-dissolve headend (HAO) was started up at the La Hague plant to allow the treatment of oxide fuels clad with stainless steel or Zircaloy. Current plans for the future call for:

1. Installation of a new headend, MAR-400, at Marcoule and transfer of all gas-graphite reactor fuel reprocessing to Marcoule as of 1985.

2. Expansion of La Hague capacity to $1600 \mathrm{t} / \mathrm{yr}$ by the early 1990s. This involves construction of UP3, which is to be dedicated to foreign fuels for a 10-year period, and expansion of UP2 to $800 \mathrm{t} / \mathrm{yr}$, with additional head-end facilities.

France also has an advanced FBR fuel reprocessing technology development program.

Thermal Reactor Fuel Reprocessing

Marcoule UP1. The first large French reprocessing facility, UP1, is still in operation, having reprocessed some $12,000 \mathrm{t}$ of spent fuel over 25 years.(a) It started up in 1958 and was originally designed for the production of plutonium from magnesium-zirconium clad, natural uranium GCR fuel for the French military program. Design capacity is 4.5 to $6 \mathrm{tHM} /$ day. The plant was later adapted to reprocess EDF power reactor fuel, also natural uranium but with higher burn-ups. Marcoule UP1 was originally designed for batch operation;

(a) J. Lefevre, 1983, CEA, Letter to P. J. Mellinger, PNL, September 7, 1983. 
continuous dissolution was installed in 1964. Used fuel from the gas graphite reactors is cooled for varying. length of time, but usually less than one year, in ponds at the power stations, to allow sufficient cooling and radioactive decay before the fuel is transported to COGEMA's facilities. On arrival at the reprocessing plant, it is stored in ponds until capacity in the plant is available for treating it. Before reprocessing, the irradiated fuel from gas graphite reactors must be separated from the other components present by underwater operations. Cutting and boring machines are used to separate graphite from the fuel, the magnesium is dissolved in a chemical stripping operation, and the natural uranium rod is then dissolved.

Solvent extraction is performed mainly in mixer-settlers. Two cycles or more are enough for plutonium purification. The second cycle has been achieved with pulsed columns since 1968. The use of uranium(IV) as reductant for plutonium partitioning has greatly improved the purification of the plutonium end-product.

A new fuel reception and decladding installation is being set up to meet France's total reprocessing requirements for natural-uranium metal fuel, by which time (1985) La Hague installations will be reserved for LWR fuel reprocessing. UP1 capacity should then reach $800 \mathrm{tU}$ per year. (a)

La Hague Reprocessing Complex. The UP2 plant at La Hague, built to reprocess France's civilian gas-cooled reactor (GCR) fuels, was commissioned in 1967. It was equipped for mechanical removal of the cladding, continuous dissolution of the uranium-molybdenum alloy, separation of uranium, plutonium and fission products by the conventional PUREX solvent extraction process, a throughput of 4-5 tHM/d and contact maintenance. As noted above, it is planned to phase out reprocessing of GCR fuels at La Hague in the next few years.

In 1976 a new chop-leach head-end plant (HAO) came on-line at La Hague to prepare oxide fuels for treatment in the UP2 solvent extraction system. This installation is designed to handle fuel elements that vary in design, weight and burnup, coming from both French and foreign reactors. 0xide fuels are

(a) J. Lefevre, 1983, CEA, Letter to P. J. Mellinger, PNL, September 7, 1983. 
cooled at least 9 months at the reactor and another 27 months at the reprocessing plant. Designed for remote maintenance, HAO was equipped with one dry chopping machine and four dissolvers. The advertised design capacity of $400 \mathrm{tHM} / \mathrm{yr}$ was calculated on the assumptions that 1) the shear could handle four LWR assemblies per day, 2) each of the dissolvers could handle the chopped fuel from one assembly each day, 3) the average weight of heavy metal in each assembly would be $500 \mathrm{~kg}$ and 4 ) the plant would operate 300 days/yr, with a $66 \%$ on-stream efficiency during those 300 days.

The head-end plant now actually operates at a nominal capacity of $300 \mathrm{tHM} / \mathrm{yr}$ (30 t/month, with two months down-time each year for maintenance), as a result of one dissolver being taken out of service in 1980. Actual annual throughput to date has been less than this for several reasons: each year, UP2 has processed its assigned load of GCR fuel, and HAO has operated only part of the year; the spent fuel assemblies handled by the oxide head end have averaged much less than $500 \mathrm{~kg} /$ assembly; and time has been lost during the LWR fuel campaigns by having to adjust the chopping machine to each new fuel design. However, as shown in Table 5, the throughput of oxide fuels has increased each year, reaching a total of $221 \mathrm{t}$ in 8 months' operation in 1983. During one month in 1982, UP2 actually exceeded the $30 \mathrm{tHM} / \mathrm{mo}$ nominal capacity.

COGEMA is conducting a major expansion program at La Hague, designed to give a total oxide fuel reprocessing capacity of $1600 \mathrm{tU}$ by the end of the present decade: $800 \mathrm{tU} / \mathrm{yr}$ in UP3, a new twin-line plant to start up in 1988-89; and 800 tU/yr in an expanded UP2 complex, UP2-800, which will have a new head-end and first separation stage and is to come on-line in the early 1990s.(a)

COGEMA is committed to reprocess 6000 tHM of foreign spent fuel by 1995 (Table 6 ). The company has placed three types of contracts:

- Type 1 contracts cover 514 tU, most of which has been reprocessed. These contracts had a fixed price and a guaranteed time of service, and left the wastes with COGEMA. About half were renegotiated later to provide for a higher price and waste return to the customer.

(a) J. Lefevre, 1983, CEA, Letter to P. J. Mellinger, PNL, September 7, 1983. 
TABLE 5. Amounts of Spent Fuel Reprocessed at La Hague UP2 Plant(37)

Amount of Spent Fuel Processed, tHM

\begin{tabular}{|c|c|c|c|c|c|c|c|}
\hline $1967-1975$ & $1976 / 77$ & 1978 & 1979 & 1980 & 1981 & $\begin{array}{c}1982 \\
\text { (1st Half) } \\
\end{array}$ & $\begin{array}{c}1983^{(46)} \\
(8 \text { months }) \\
\end{array}$ \\
\hline 2365 & 569 & 372 & 264 & 268 & 275 & -- & NA \\
\hline-- & 31.7 & 36.8 & 75.3 & 102 & 110 & $154^{(c)}$ & 221 \\
\hline-- & -- & -- & 2.2 & 1.6 & 1.9 & -- & -- \\
\hline
\end{tabular}

\footnotetext{
(a) Burnup: 3500-5500 MWd/t.

(b) Average burnup: $30,000 \mathrm{MWd} / \mathrm{t}$.

(c) Six-month operation; $36 \mathrm{t}$ fuel handled in June 1982.

(d) Average burnup: $>50,000 \mathrm{MWd} / \mathrm{t}$.
} 
TABLE 6. COGEMA's Foreign Fuel Reprocessing Contracts, tHM

\begin{tabular}{|c|c|c|c|}
\hline Country & $\begin{array}{c}\text { Type 1 } \\
(1971-1974) \\
\end{array}$ & $\begin{array}{c}\text { Type } 2 \\
(1974-1976) \\
\end{array}$ & $\begin{array}{c}\text { Type } 3 \\
\text { (After 1976) } \\
\end{array}$ \\
\hline Japan & 151 & -- & 2200 \\
\hline FRG & 210 & 327 & 2141 \\
\hline Sweden & 57 & -- & 672 \\
\hline Switzerland & 39 & 50 & 469 \\
\hline Spain & -- & $?$ & -- \\
\hline Bel gium & 4 & 99 & 398 \\
\hline Netherlands & 40 & -- & 120 \\
\hline TOTAL & 514 & 713 & $\overline{6000}$ \\
\hline $\begin{array}{l}\text { Received } \\
\text { Through 6-30-81 }\end{array}$ & 459 & 226 & 51 \\
\hline $\begin{array}{l}\text { Reprocessed } \\
\text { Through } 6-30-81\end{array}$ & $\sim 250$ & 75 & \\
\hline
\end{tabular}

- Type 2 contracts cover $713 \mathrm{tU}$. They have higher prices and no guaranteed time of service, and they require return of all reprocessing wastes beginning in 1990 .

- Type 3 or "baseload customer" contracts cover $6000 \mathrm{tU}$. The foreign customers, who have the right to the full UP3 capacity until the contracts are completed (estimated at 1995), pay all investment and operating costs and retain ownership of the recovered uranium and plutonium. The plutonium will be returned to the originating country only upon certification it will be covered by IAEA safeguards. They must adhere to firm delivery schedules for their spent fuel; they must remove from France all reprocessing wastes, including such items as fuel cladding and contaminated gloves; and the reprocessing price is to be set on a cost-plus-fixed-fee basis. Once these contracts are completed, UP3 is to be available full-time for French fuels. Fast Breeder Reactor Fuel Reprocessing

Fast breeder reactor fuel research and development have been under way in France for over 15 years. In 1968, the first Rapsodie fuel pins were reprocessed in the Fontenay-aux-Roses laboratory. From 1969 to 1979, over a ton of 
very high burnup mixed oxide fuel was reprocessed at La Hague in the AT-1 pilot installation.(a) This pilot plant features a chop-leach head-end (rotary shear); feed filtration; PUREX separations process; geometrically safe minimixer-settlers; and coprecipitation of uranium and plutonium for the purified nitrates.

At Marcoule, in the SAP pilot installation, subassemblies from the Phenix and the German KNK fast reactors were reprocessed: from 1979 through 1982 , 5 tHM of standard-type Phenix mixed oxide, with an average burnup of $65,000 \mathrm{MWd} / \mathrm{t}$ were reprocessed, producing $900 \mathrm{~kg}$ of plutonium. (a)

The 25-kg/day SAP pilot plant was originally commissioned in 1962 for natural uranium fuel reprocessing development. It was re-equipped in 1974 with a new headend designed to handle FBR fuels. SAP studies have emphasized fuel element dismantling, continuous dissolution and annular pulse columns. The facility is now being expanded into an industrial demonstration facility through addition of a new chop-leach head-end, TOR (Traitement d'oxydes rapides). It is designed for remote maintenance and for a throughput of 5 tHM/yr, with startup scheduled for 1985. The head end has two parallel equipment lines--one using proven technology (shear, batch dissolution, centrifugal clarification of the fuel solution), and a set of experimental units that can be positioned on a by-pass to the main process line. TOR is scheduled to process portions of the fuel from the 250-MWe Phenix FBR and the first fuel discharged from Superphenix.

An intermediate-scale, 50-tHM/yr plant, Marcoule-2000 (formerly known as PURR), is in the design phase. Formerly scaled at $120 \mathrm{tHM} / \mathrm{yr}$, it was intended to meet the needs of Superphenix (1250 MWe) and of 2 to 4 subsequent 1500-MWe FBRs and was designed for fuels characterized by a maximum burnup of $125,000 \mathrm{MWd} / \mathrm{t}$ and a cooling time of three years. The capacity has been scaled back to be consistent with presently evolving reactor plans. The decision on construction will depend on the future of the French breeder program, which is under evaluation.

(a) J. Lefevre, 1983, CEA, Letter to P. J. Mellinger, PNL, September 7, 1983. 
In a related effort, nearly 6 tHM in Phenix FBR fuel was reprocessed in the UP2 plant at La Hague in the 1979-1981 period: subassemblies were cleaned and dismantled at Marcoule and shipped to La Hague where fuel pins were chopped and dissolved in the HAO head end, and the solution was diluted with GCR fuel solution and processed through the UP2 solvent extraction system. Thus, a total of 16 tHM of FBR fuel had been reprocessed in France by the end of 1982 . The plutonium produced has been used for the fabrication of fast reactor fuel. By the end of $1982,3 / 4$ of the fuel in the Phenix fast reactor came from reprocessed FBR fuel. (a)

High-level waste concentrate is stored in the acid form in stirred, cooled stainless-steel tanks. A HLW vitrification plant (AVM) has been operating at Marcoule since 1978, and COGEMA is installing similar facilities at La Hague. The waste-glass canisters are stored in a vault pending their transfer to a geologic waste repository.

Intermediate-level wastes are solidified in bitumen or cement and placed in surface storage facilities adjacent to the La Hague reprocessing plant.

GERMANY (FEDERAL REPUBLIC) ${ }^{(48-61)}$

The Federal Republic of Germany (FRG) has a strong nuclear program, embracing the construction of BWRs and PWRs, the demonstration of advanced reactor technology (HTGR and FBR) and the development of complete domestic fuel cycle capability.

The federal government supports an extensive nuclear R\&D program, administered through the Ministry for Science and Technology (BMFT), but requires participation by private industry in major demonstration projects. Commercial activities for the back end of the fuel cycle are handled by DWK, the nuclear fuel reprocessing company (spent fuel storage, reprocessing, treatment and storage of reprocessing wastes), and by ALKEM ( $\mathrm{PuO}_{2} / \mathrm{UO}_{2}$ mixed oxide fuel fabrication and the treatment of alpha-contaminated wastes from fuel fabrication). Development of reprocessing technology is centered at the Karlsruhe and Jülich nuclear research centers ( $K f K$ and KFA, respectively) and the WAK plant (reprocessing pilot plant adjacent to KfK). The Jülich center is concerned with

(a) J. Lefevre, 1983, CEA, Letter to P. J. Mellinger, PNL, September 7, 1983. 
reprocessing of thorium-containing HTGR fuels, while Karlsruhe has hot-cell and semi-works facilities devoted to LWR and LMFBR fuel recycle studies.

Nuclear Power Projections

Capacity $(\text { GWe })^{(2)}$

LWR

HTR

FBR

Spent Fuel Arisings (tHM) (a)

\begin{tabular}{|c|c|c|c|c|}
\hline 1980 & 1985 & 1990 & 1995 & 2000 \\
\hline \multirow[t]{3}{*}{8.6} & 16.1 & 23.6 & 26.0 & 28.0 \\
\hline & 0.3 & 0.3 & 0.3 & 0.3 \\
\hline & & 0.3 & 0.3 & 0.3 \\
\hline
\end{tabular}

$200 \quad 390$

530

600

700

$960 \quad 2,200$

4,500

$7,400 \quad 11,000$

Fuel Cycle Policy

The Federal Republic of Germany has an extensive commercial fuel cycle program, which has been based for many years on the concept of recycling plutonium to breeder reactors, and possibly to LWRs. It includes worldwide uranium exploration, participation in international centrifuge enrichment projects, extensive $\mathrm{UO}_{2}$ and mixed-oxide fuel fabrication capability, and the development of commercial fuel reprocessing and waste management facilities.

Several years ago, adequate provision for nuclear waste management became a precondition for issuing construction permits for additional reactors in Germany. In response to this requirement, the FRG nuclear utilities set up a company (DWK) that started planning for a complete spent fuel recycle and waste management center, the Nukleares Entsorgungs Zentrum (NEZ), at Gorleben, Lower Saxony. The NEZ provided for interim spent fuel storage, reprocessing, uranium and plutonium conversion and storage, MOX fuel fabrication, conditioning of radioactive wastes, and disposal of solidified wastes in a salt repository--all at the same site. A $12-\mathrm{km}^{2}$ area near the town of Gorleben, Lower Saxony, was selected and purchased, and site characterization and facility design activities were begun. In May 1979, the government of Lower Saxony decided that

(a) Data obtained from Reference 7 , modified by PNL to reflect current power station construction schedules. 
construction of the large reprocessing plant at Gorleben was technically but not politically feasible and recommended that reprocessing be done elsewhere in smaller plants.

Current FRG strategy includes: 1) thorough evaluation of the final storage of spent LWR fuels as an alternative to reprocessing; 2) indefinite storage of spent fuels at one or more AFRs, using the dry storage concept; 3 ) interim reprocessing of FRG fuels (2700 t) by Cogema at La Hague; 4) construction of one or more small (350-t/yr) reprocessing plants; 5) construction of a salt dome repository at Gorleben for HLW, TRU wastes and possibly spent fuels; and 6) conversion of the abandoned Konrad iron mine into a repository for non-TRU wastes.

\section{Reprocessing Activities}

WAK Pilot Plant

West Germany has had a fuel reprocessing pilot plant, the WAK plant at the Karlsruhe Nuclear Research Center, in hot operation since 1971. Owned by KfK but currently operated by a DWK subsidiary, the facility has been used for routine processing of spent fuel and as a test facility for new processes and components developed at KfK's Institute for Hot Chemistry. The features of the 10-35 tHM/yr plant are:

1. Chop-leach headend. The fuel element end pieces are removed with a hacksaw, and the single pins are sheared into $50 \mathrm{~mm}$ sections. Dissolver solution is filtered for removal of insoluble residues.

2. A PUREX solvent extraction flow sheet using mixer-settlers. The plant has one partitioning cycle, one decontamination cycle each for uranium and plutonium, silica-gel filtration of the uranium product, and ion exchange purification of the plutonium product.

3. HLLW concentration to $700 \mathrm{l} / \mathrm{t}$ prior to storage. The waste is neutralized and stored in stainless-steel tanks.

4. Recycling of raffinate streams. 
5. Special measures to confine tritium to the headend of the plant.

6. Equipment repair and replacement is done using decontamination followed by contact handling.

The WAK plant was shut down in 1980 to allow replacement of the dissolver, which had developed a leak. At the time it was shut down, the plant had processed oxide fuels from various sources, containing 114 tHM. Treatment of high-burnup fuel in a two-cycle process was demonstrated in a campaign in which 23 tHM of spent fuel with burnups as high as 39,000 MWd/t were reprocessed. The major difference noted by the high burnup campaign was a significant increase in insoluble residues. These residues caused some reportedly minor hydraulic problems in the first extraction cycle and clogged pipes.

In October 1982, the plant went back on stream, following 27 months of repairs. Not only was a new dissolver installed, but a new disassembly machine was installed in the head-end cell, much of the mild steel piping in the steam supply system was replaced with stainless steel, and larger lead-shielded boxes were installed with new instruments and remote handling devices.

The WAK staff have also done advanced work in modeling uranium-plutonium partitioning by solvent extraction. Computer simulation is used to calculate multicomponent distribution data for U(IV), U(VI), $\mathrm{Pu}\left(\right.$ III), $\mathrm{Pu}(\mathrm{IV}), \mathrm{HNO}_{3}$, and hydrazine.

\section{Commercial Plant for LWR Fuels}

When the DWK proposal to build a 1400-tU/yr reprocessing plant at Gorleben was rejected by the Lower Saxony government, the company began to plan for one or more $350 \mathrm{t} / \mathrm{yr}$ facilities. Current indications are that the facility will be designed to handle about 1000 LWR fuel elements per year, with a maximum burnup of 40,000 MWd/t and cooled for seven years; it will have a bundle shear which can operate on the complete fuel element; and a bowl centrifuge will be installed to clarify the feed to the solvent extraction system. Current solvent-extraction system designs, based on a PUREX flow-sheet, make use of both pulsed columns and mixer-settlers, and provide a fourth single-stage mixer-settler for solvent cleanup with hydrazine. Overall plant design is 
based on a "canyon" concept in which plant modules are mounted in such a way that they can be removed remotely for maintenance without the need to decontaminate processing cells.

Plant sites in four different states have been considered. The list has now been reduced to two: one at Wackersdorf near Schwandorf in Bavaria and the other at Dragahn, about $30 \mathrm{~km}$ from the Gorleben site in Lower Saxony. Formal licensing procedures have commenced for both sites and could lead to a first construction permit for both of them by the end of 1984 or early 1985. The licensing application encompasses a 1500-tU spent fuel storage area, a plant for reprocessing and treatment of HLW and ILW, a plant for uranium decontamination and LLW treatment, and a plant for MOX fuel fabrication.

\section{R\&D--Reprocessing of LWR and LMFBR Fuels}

Development of advanced technology for reprocessing LWR and LMFBR fuels is divided between KfK's Institute for Hot Chemistry and the TEKO nonradioactive semiworks facility, also owned by KfK but operated by WAK mbH.

The Institute for Hot Chemistry is equipped with facilities to study such areas as solvent extraction, process flow sheets, plutonium chemistry, and solvent cleanup. The Institute also has a complete miniature reprocessing plant (the Milli Facility) constructed in hot cells. Milli has three cycles of 16-unit mixer-settlers and can process 500 to $600 \mathrm{~g}$ of metal per batch. Work has been done in the past on processes for FBR fuels, but current emphas is is on PUREX flow sheets for LWR fuels.

Several uses for electroprocesses have been studied to minimize the use of salts in the PUREX process and thus minimize waste volumes:

- Used solvent is washed with hydrazine saturated with $\mathrm{CO}_{2}$, instead of $\mathrm{Na}_{2} \mathrm{CO}_{3}$, and the hydrazine is destroyed electrolytically.

- Techniques have been developed for electrolytic reduction of $\mathrm{Pu}($ IV) to $\mathrm{Pu}(\mathrm{III})$ and for plutonium reoxidation in the PUREX U-Pu partitioning cycle. The solvent extraction unit, constructed of titanium, is used as the cathode. The process has been tested in both pulse 
columns and mixer-settlers in Institute facilities, and an electrolytic mixer-settler has been installed in the plutonium second cycle at the WAK plant.

- Electrolytic destruction of nitrate and oxalate in waste streams has been investigated.

In 1983, the Milli facility successfully completed a reprocessing campaign with high burnup and relatively short-cooled breeder fuel. The feed was $7 \mathrm{~kg}$ HM of breeder fuel from the FRG's Compact Sodium Cooled Nuclear Test Reactor (KNK II) which had a peak exposure of 100,000 MWd/tHM and had been cooled for less than 10 months.

The TEKO semiworks is used for nonradioactive testing of components and processes for the commercial reprocessing plant. It was designed when the 1400-tU/yr plant was still a viable concept, and much of the equipment has twice the capacity required for the $350 \mathrm{t} / \mathrm{yr}$ plant now planned. Major TEKO components include: a $4-t / d$ fuel shear; a $4 \mathrm{t} / \mathrm{d}$ dissolver; a bowl centrifuge for clarifying feed to the solvent extraction system; glass pulsed columns for several operations and an 8-t/d mixer-settler unit for the uranium second cycle; and a "tritium trap" mixer-settler designed to remove tritium-containing water from the organic phase and recycle it to the high-level waste stream.

At Lahde ( $90 \mathrm{~km}$ west of Hanover), DWK has converted the turbine room of a decommissioned fossil power station to a remote maintenance test facility (LAHDE). In this facility, representative sections of the proposed WA-350 reprocessing plant have been reproduced full scale. The concept uses a modular design and manipulator/crane handling. The equipment is placed in modules located on both sides of a long shielded cell. Remote handling equipment is moved along a narrow passageway between the equipment modules. Remotely handled connections or "jumpers" are used to connect the equipment modules to each other or to external facilities.

\section{R\&D--Reprocessing of HTGR Fuels}

Given overall responsibility to develop the HTGR fuel cycle, KFA has been studying HTGR fuels reprocessing since 1966. An extensive collaberation program has been carried out with the US in this area over the past 6-8 years, 
associated with the US HTGR fuel cycle programs at G.A. Techologies in San Diego, California. The German efforts have focused since 1970 on development of a process with the following major features:

1. The process must handle both fissile (enriched $\mathrm{UO}_{2}$ ) and fertile $\left(\mathrm{ThO}_{2} \mathbf{-}^{233} \mathrm{U}\right)$ materials, both in the form of particles embedded in a graphite matrix.

2. A grind-burn-leach headend is provided to remove the graphite matrix and put the fuel particles into solution. A continuous dissolver has been developed for this operation.

3. A THOREX solvent extraction process is used to separate the thorium, uranium, and fission products in the fertile particles, while a PUREX process recovers the uranium in the fissile particles.

4. The bred $233 \mathrm{U}$ is fabricated into new fuel elements for recycle.

To provide hot demonstration of the process, KFA has constructed a $2-\mathrm{kg} / \mathrm{d}$ pilot plant, JUPITER (Jülich Pilot Plant for Thorium Element Reprocessing). Hot startup, originally scheduled for 1980, has been delayed for several years by 1 icensing issues.

\section{Reprocessing Wastes}

In a joint project, BMFT and DWK are building a waste vitrification pilot plant, PAMELA, on the Eurochemic site at Mol, Belgium. It is to demonstrate the liquid-fed ceramic melter immobilization process, using existing Eurochemic HLW, and will probably be the forerunner of vitrification plants to be installed at FRG's reprocessing plants. Startup is scheduled in 1985.

Non-HLW alpha-contaminated (TRU) wastes are currently fixed in concrete. A bituminization plant began operation at Karlsruhe in 1972 but was shut down in 1977 because of questions concerning the suitability of bitumen. Extensive research and development is under way, much of it applicable to TRU wastes. Hahn-Meitner Institut and Karlsruhe researchers are studying the behavior of actinides in glass. Ceramic waste forms are being examined specifically for TRU wastes at Karlsruhe, while several sites are evaluating concrete for nonhigh-level waste disposal, including cladding disposal. The Karlsruhe Research 
Center fabricated and tested the acid digestion unit for TRU wastes in the ALONA facility at Mol, Belgium. NUKEM, near Hanau, is testing two pyrohydrolys is systems for TRU wastes, one for solid wastes and one for spent organic solvent. The facility is also planning to install a waste washing system. The waste management facility at Karlsruhe provides decontamination and size reduction (scrapping) services for the Nuclear Research Center, the WAK Reprocessing Plant, the KNK and MZFR experimental reactors, ALKEM, and the European Institute of Transuranium Elements. The average annual throughput of the Karlsruhe facility is 7500 components decontaminated for repair and reuse and 300 tonnes of material (mainly non-TRU) size-reduced for disposal in drums.

FRG authorities feel that removal of some or all of the following radionuclides from reprocessing plant off-gas streams will be required: ${ }^{85} \mathrm{Kr},{ }^{129} \mathrm{I}$, tritium and ${ }^{14} \mathrm{C}$. Accordingly, processes and hardware for this purpose have been tested at both KfK (LWR fuels) and KFA (HTGR fuels).

$\underline{\operatorname{INDIA}}^{(16,17,62-66)}$

India depends heavily on a growing nuclear power capacity to augment the nation's electric power supply. Their nuclear program started with the installation of two BWRs, is continuing with CANDU-type HWRs fueled with natural uranium, and is to proceed to FBRs fueled with plutonium and eventually to selfsustaining thorium-uranium cycle reactors. Development of complete indigenous fuel cycle capability, including reprocessing, is a major program objective.

Essentially all activities concerned with the back end of the fuel cycle are conducted by the various divisions of the Department of Atomic Energy. Major components include the Bhabha Atomic Research Center at Trombay (near Bombay), the Nuclear Fuels Division (fuel manufacture) and the fuel reprocessing organizations at the Tarapur and Kalpakkam power stations. 
Nuclear Power Projections

\begin{tabular}{|c|c|c|c|c|c|}
\hline & 1980 & 1985 & 1990 & 1995 & 2000 \\
\hline \multicolumn{6}{|l|}{ Capacity (GWe) (2) } \\
\hline BWR & 0.4 & 0.4 & 0.4 & 0.4 & 0.4 \\
\hline HWR & 0.2 & 0.8 & 1.5 & 2.6 & 4.0 \\
\hline \multicolumn{6}{|c|}{ Spent Fuel Arisings (tHM) (a) } \\
\hline Annual, HWR & 30 & 85 & 180 & 210 & 420 \\
\hline \multicolumn{6}{|l|}{ Cumulative } \\
\hline BWR & 200 & 290 & 380 & 470 & 600 \\
\hline HWR & 160 & 500 & 1,200 & 2,300 & 4,400 \\
\hline
\end{tabular}

Fuel Cycle Policy

National objectives continue to emphasize development of complete fuel cycle self-sufficiency, with domestic capability for uranium milling and conversion to $\mathrm{UO}_{2}$, fuel fabrication, reprocessing, and waste treatment and disposal.

Reprocessing Activities

Reprocessing of spent fuels was started in 1964 at a 0.1 to $0.15 \mathrm{t} /$ day PUREX-process pilot plant for research reactor fuels at Trombay. Designed to reprocess the fuel from a test reactor, the Trombay plant produced the plutonium used in India's nuclear weapons test. It was shut down in 1974, decontaminated, and prepared for future alterations to allow its continued use in reprocessing research reactor fuels. In April 1983, the modifications were nearly complete and test runs under way. As originally constructed, the plant was designed for direct maintenance and used chemical decladding, pulse columns for co-decontamination, partitioning and uranium purification, and anion exchange for final plutonium purification.

Based on Trombay experience, a $0.5-t / d$ reprocessing plant has been built at Tarapur to handle HWR and BWR fuels. The plant is equipped with a chopleach headend and is designed to use a slightly "modified" PUREX main line and

(a) Data obtained from Reference 6 , modified by PNL to fit current nuclear power forecasts. 
conversion of uranium and plutonium to oxides. Except for the head-end cell, which has provisions for remote maintenance, the rest of the plant uses remote decontamination followed by direct maintenance. This facility began reprocessing fuel in December 1982 from the Rajasthan nuclear power station under IAEA inspection. A second $0.5-t / d$ plant, being designed for the Kalpakkam site, is to process HWR and FBR fuels using separate streams. This plant will process spent fuel from the twin Kalpakkam reactors and will have adjacent facilities for reprocessing mixed-carbide fuels from the FBTR at that site. The Reactor Research Center at Kalpakkam has been involved in R\&D activities in such areas as the development of single pin chopper, dissolvers, feed clarification, centrifugal contactors and mixer-settlers for application to fast reactor fuel reprocessing.

Liquid HLW is concentrated in evaporators, then stored in water-cooled stainless steel tanks located in underground concrete vaults. For the long term, the HLW is to be vitrified in a pot calciner-melter process, then stored underground in an engineered storage facility until the canisters can be moved to a geologic disposal site. No treatment or fixation of non-HLW alphacontaminated (TRU) wastes is performed; however, both incineration and wet oxidation followed by fixation in either cement or bitumen are being evaluated.

$\underline{\operatorname{ISRAEL}}(17,67)$

Israel imports virtually all of its commercial energy in the form of oil or coal. Since the return of oil-producing facilities to Egypt as part of the 1979 peace settlement, Israel has converted most electric generating plants to use coal.

Interest in nuclear power began early and an Atomic Energy Commission was established in 1952. A 26-MW natural uranium research reactor was built at Dimona in the early sixties; subsequently, a 5-MW research reactor was built at Nahal Soreg, south of Tel Aviv. The latter facility is covered by IAEA safeguards; the former is not.

The Israeli government at one time planned to build a 900-MWe LWR, but the project has been postponed indefinitely. A reprocessing plant capable of separating out weapons grade plutonium from spent fuel is reportedly in operation at Dimona. 
$\underline{\operatorname{ITALY}}(68-70)$

Italy has a diversified nuclear program based primarily upon light-water reactors but including the construction of two advanced reactors, a HWR and a test breeder. The country is aiming for self-sufficiency in the nuclear fuel cycle.

The nuclear industry is state-owned to a great extent, with major responsibilities being handled as follows: ENEL, operation of power plants; Ansaldo, reactor plant construction; AGIP S.p.A., fuel cycle; and ENEA (formerly CNEN), R\&D and regulatory matters. ENEA operates nuclear research centers near Rome, Turin (northern Italy) and Rotondella (southern Italy).

Nuclear Power Projections

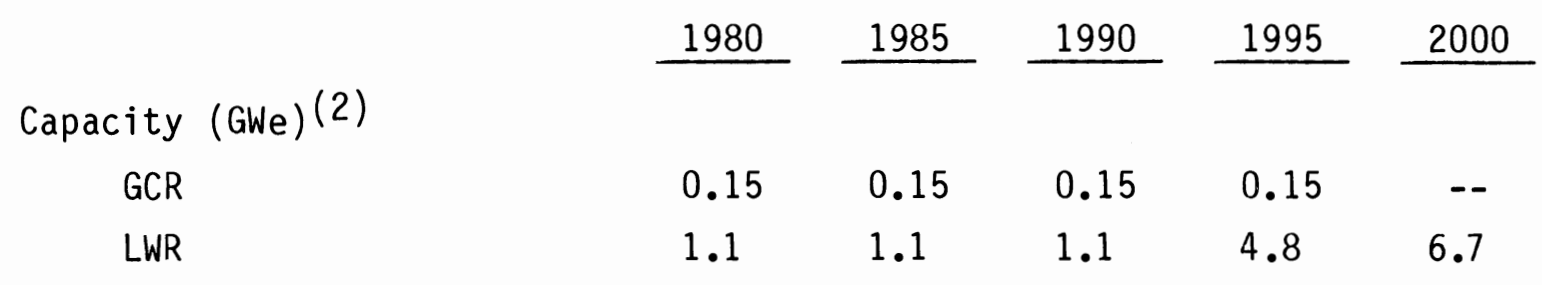

Spent Fuel Arisings (tHM) (a)

Annual, LWR

Cumulative

GCR (metal fuels)

LWR
30

900

160
30

1,200

320
30

170

240

$\begin{array}{rr}1,500 & 1,600 \\ 500 & 1,000\end{array}$

1,700

2,000

\section{Fuel Cycle Policy}

Italy's long-term goal is for self-sufficiency in the nuclear fuel cycle, with domestic reprocessing of spent fuels and recycle of plutonium to a fast breeder reactor, and considerable progress has been made in this direction. The country owns a share of Eurodif, the company which operates the multinational uranium enrichment plant in France; capability for fabricating various types of fuels, including mixed oxide elements for FBRs, has been demonstrated; two small, special-purpose reprocessing plants have been built and operated successfully, and construction of a commercial fuel reprocessing plant is being

(a) Data obtained from Reference 7 , modified by PNL to reflect current power station construction schedules. 
concluded; and an Italian HLW vitrification process has been developed and tested in a nonradioactive pilot plant.

Current nuclear strategy assumes that, for the time being, there is no need to provide AFR spent fuel storage; that HLW will be vitrified and stored for upwards of 50 years before emplacement in a repository; that a geologic repository, probably in a clay formation, can be developed by the time it is needed; and that LLW can be disposed of by sea-dumping under OECD/NEA surveillance, in accord with the London Sea Dumping Convention.

\section{Reprocessing Activities}

Italy has two pilot-scale reprocessing plants, EUREX and ITREC, and the construction of an industrial-scale plant (1200 tHM/yr) is being evaluated. It may be located near either of the pilot plants. In the interim, limited quantities of Magnox fuel are being treated by BNFL at Sellafield (UK).

The EUREX pilot plant, built between 1965 and 1968 and located at the Saluggia Center in Northern Italy, initially operated between 1970 and 1974 . It was first designed to reprocess about $30 \mathrm{~kg} /$ day of highly enriched MTR fuels and later modified to treat 50 to $100 \mathrm{~kg} /$ day of natural and low-enrichment uranium fuels. The plant used mixer-settlers, the classical PUREX process in two cycles, final decontamination of the uranium product by silica gel treatment, and final decontamination of the plutonium product by a tertiary amine extraction cycle. The pilot plant has since been equipped with a new head-end cell with a shear to reprocess power reactor fuels. Reprocessing experiments have begun on CANDU-type fuel elements from Canada.

The ITREC pilot plant at the Trisaia Center in southern Italy was completed in 1968 and started active operation in about 1975. It has a chop-leach headend and was designed to reprocess $15 \mathrm{~kg} /$ day of thorium-uranium fuel from the Elk River reactor under a joint program with the U.S. The pilot plant used one decontamination cycle and included remote refabrication of fuel. The solvent extraction operation (THOREX) is carried out in slab mixer-settler banks with $30 \%$ TBP. The plant's current assignment is to process fuel from Italy's 120-MWt fast fuel test reactor (PEC) with a capacity of about $10 \mathrm{~kg} \mathrm{U/day.}$ 
Alternative fuel cycle techniques, including coprocessing to yield a mixed uranium-plutonium product stream, are under investigation.

$\underline{\operatorname{JAPAN}}(71-77)$

The Japanese government actively supports nuclear power as the primary means of reducing dependence upon foreign energy sources and considers it the top-priority energy source.

The government's strategy is to install LWRs for near-term power production; develop an advanced thermal reactor (ATR) based on a LW-cooled, HWmoderated concept; and aim for commercial operation of fast breeder reactors by the year 2010. The government also considers it essential that Japan build an independent commercial nuclear fuel cycle capability, including export of nuclear equipment and technology. Fuel cycle strategy calls for maximum utilization of plutonium resources, with $\mathrm{Pu}$ recycle to FBRs, ATRs and LWRs.

Development of fuel cycle and waste management technology is handled primarily by the government-owned Power Reactor and Nuclear Fuel Development Corporation (PNC) and the Japan Atomic Energy Research Institute (JAERI), supported by other government institutes and private industry. Construction and operation of commercial fuel reprocessing facilities is the responsibility of Japan Nuclear Fuel Service, Limited (JNFS).

Nuclear Power Projections

\begin{tabular}{|c|c|c|c|c|c|}
\hline & 1980 & 1985 & 1990 & 1995 & 2000 \\
\hline \multicolumn{6}{|c|}{ Capacity (GWe')(2) } \\
\hline GCR & 0.19 & 0.19 & 0.19 & 0.19 & -- \\
\hline LWR & 14.1 & 21 & 31 & 40 & 50 \\
\hline HWR & 0.15 & 0.15 & 0.15 & 0.15 & 0.15 \\
\hline FBR & -- & -- & 0.28 & 0.28 & 0.28 \\
\hline
\end{tabular}


Spent Fuel Arisings (tHM) (a)

$\begin{array}{lrrrrr}\begin{array}{l}\text { Annual, LWR } \\ \text { Cumulative }\end{array} & 450 & 620 & 960 & 1,100 & 1,400 \\ \begin{array}{l}\text { GCR (metal fuels) } \\ \text { LWR }\end{array} & 690 & 900 & 1,150 & 1,300 & 1,500 \\ & 1,400 & 4,100 & 8,200 & 13,000 & 20,000\end{array}$

\section{Fuel Cycle Policy}

The Japanese have very limited indigenous uranium resources and endorse a national commitment to become self-sufficient with regard to their nuclear fuel supply. Thus, they are depending heavily on fuel reprocessing and plutonium recycle--to breeder reactors in the long term, to thermal reactors (ATRs and LWRs) in the near term. In keeping with these objectives, Japan is developing domestic industrial capability for uranium enrichment, reprocessing and waste treatment. Since a commercial-scale reprocessing plant will not be in operation in Japan before the early 1990s, the utilities have contracted to have over $4600 \mathrm{tU}$ of their fuel treated by foreign reprocessors.

Waste management strategy calls for vitrification of HLW, volume reduction and immobilization of other wastes, and surface storage of waste packages until disposal is provided.

Reprocessing Activities

Japan started up a reprocessing pilot plant, PNC's Tokai Works facility, in 1977. Constructed by JGC (Japan) and SGN (France), it was built to develop and test reprocessing technology for LWR fuels and to give the Japanese practical reprocessing experience. Designed to yield a daily throughput of 0.7 tHM, the plant uses a chop-leach headend and a PUREX solvent extraction process with mixer-settler contactors. Mechanical equipment in the chop-leach section is designed to be maintained remotely, with provision for remote decontamination of the cell and equipment in case direct contact is required for major repair or modification. All other plant areas are to be maintained directly after the necessary decontamination.

(a) Data obtained from Reference 6 , modified by PNL to fit current nuclear power forecasts. 
The Tokai plant had reprocessed a total of 175 tHM of LWR spent fuel as of December 1982. The plant also had tested several coprocessing flowsheets, designed to yield a mixed PU-U stream of controlled composition, and PNC has developed a technique for direct denitration of the co-conversion product to yield fuel-grade MOX. Full-scale operation of a 10-kg MOX/day facility which uses this denitration process and which has been built adjacent to the fuel reprocessing plant is expected to commence in 1984.

The plant has experienced several equipment failures: a leak in a heat exchanger of the acid-recovery evaporator, in 1978; a leak in a welded zone of a heating coil in the acid-recovery distillation column, in 1981; and small leaks in both dissolvers. All leaks have been repaired; the dissolver problems were attacked with specially designed robots that handled the inspection, abrasion and welding tasks. A new dissolver is scheduled to be installed in 1984. A commercial reprocessing plant for LWR fuels, designed for a 2-tHM/day throughput, is to be built and operated by a consortium of about 100 companies, known as Japan Nuclear Fuel Service, Limited (JNFS). Startup is planned for 1995.

With the onset of commercial reprocessing not scheduled until the early 1990s, the Japanese nuclear utilities have turned to foreign reprocessing as an interim measure. They have contracts with Cogema and BNFL for 2351 tHM and 1600 tHM, respectively. In general, these contracts require that Japan take back the reprocessing wastes, beginning in 1990. Spent fuel shipments to the reprocessors began in 1979 .

Research and Development

Japan is engaged in an extensive reprocessing $R \& D$ effort, with emphasis in the areas of head-end technology, development of solvent-extraction equipment for high-exposure, short-cooled fuels, plutonium/uranium partitioning and offgas control.

During 1981, PNC completed construction of a new major R\&D facility at the Tokai site, the Chemical Processing Facility (CPF). The building has two hot cell lines, one designed for studies of the application of the PUREX process to irradiated FBR fuels, one equipped to study HLW vitrification. In October 
1982, the CPF began basic tests on reprocessing spent fuel from Japan's experimental FBR, Joyo. Small $(\mathrm{kg})$ quantities of fuel have been processed through the facility.

PNC is also managing an intensive R\&D program directed to design and construct an FBR Fuel Reprocessing Test Facility, a $120 \mathrm{~kg} \mathrm{HM} /$ day pilot plant generally similar to the planned U.S. Breeder Reprocessing Engineering Test (BRET) facility. Construction is planned to begin in 1987, with hot operation scheduled for 1991. Development of main process units has been in progress for several years. Some components being tested are a large-scale shear, a largescale pulse-column contactor using electrolytic reduction of the plutonium, and a distillation unit for cleanup of degraded solvent.

Equipment for HLW vitrification is under development, and techniques for offgas treatment are being tested in the Tokai fuel reprocessing plant. The offgas treatment facility includes cryogenic distillation for recovery and separation of xenon and krypton. Krypton-85 will be stored onsite in pressurized steel cylinders. Non-HLW alpha-contaminated wastes (TRU) are presently being stored onsite untreated; however, research and development is under way on reduction of waste generation and volumes and on immobilization for disposal. Japan plans to build a new plant at Tokai, the Plutonium Waste Treatment Facility (PWTF), for treating and immobilizing the TRU wastes. This facility will incorporate acid digestion, incineration, and electroslag melting.

Japanese companies are studying alternative methods of recovering ${ }^{85} \mathrm{Kr}$ : porous palladium membranes for noble gas recovery from reactor offgas, charcoal sorption systems for reactor offgas, and zeolite encapsulation and charcoal sorption for immobilization of krypton.

MEXICO $(17,78)$

At one time, the government of Mexico was working toward a national goal of 20 GWe installed nuclear capacity by the year 2000 and several fuel cycle R\&D facilities were reportedly under construction at the Salazar Nuclear Center near Mexico City. One of these facilities was thought to be a pilot-scale reprocessing plant. At present, the country has two 650-MWe BWRs under 
construction at the Laguna Verde station, scheduled for completion in 1986 and 1988, and the goals for nuclear power are being re-evaluated. Current plans are to store the spent fuel from Laguna Verde onsite.(a)

Nuclear Power Projections

Capacity, GWe (total)(2)

$\frac{1985}{--} \frac{1990}{1.3} \frac{1995}{1.3} \frac{2000}{1.3}$

Spent Fuel Arisings, tHM(b)

$\begin{array}{lrrrr}\text { Annual } & -- & 40 & 40 & 40 \\ \text { Cumulative } & -- & 105 & 300 & 500\end{array}$

$\underline{\operatorname{PAKISTAN}}(16,17,79-81)$

Pakistan's national energy plan has included an objective to provide up to $50 \%$ of the country's electrical energy with nuclear power plants, and at one time authorities intended to have 24 reactors (16 GWe), chiefly LWRs, operational by the year 2000. Currently, one CANDU-type HWR (137 MWe) is in service, and authorities hope to have their first PWR operational by 1990.

Government fuel cycle policy calls for development of domestic capability for uranium production and enrichment, fuel fabrication and reprocessing. Nuclear Power Projections

Capacity (GWe) (2)

$\underline{1980 \quad 1985} \quad \underline{1990 \quad \underline{1995} \quad 2000}$

\begin{tabular}{|c|c|c|c|c|}
\hline HWR & 0.125 & 0.125 & 0.125 & 0.125 \\
\hline PWR & & & & 1.0 \\
\hline
\end{tabular}

Spent Fuel Arisings (tHM) (b)

Cumulative

HWR

$50 \quad 110$

170

230

290

PWR

$--$

150

(a) Letter from R. Bello (General Director, Instituto Nacional de Investigaciones Nucleares, Mexico) to P. J. Mellinger (PNL), August 19, 1983.

(b) Data obtained from Reference 6 , modified by PNL to fit current nuclear power forecasts. 


\section{Reprocessing Activities}

The Pakistan Institute of Science and Technology in Rawalpindi has a small laboratory-scale reprocessing facility, and Pakistan reportedly plans to set up a nuclear complex, including reprocessing capability, at the Chashma site on the Indus River in Mianwali District. A fuel fabrication plant started operations there in 1980, and construction is reportedly proceeding on a $300 \mathrm{~kg} \mathrm{~V} /$ day reprocessing plant. This plant was to have been supplied by France, but the French cancelled the contract after $95 \%$ of the design documents had been delivered, because of Pakistani refusal to sign the Non-Proliferation Treaty.

$\underline{\operatorname{SPAIN}}^{(82,83)}$

The Spanish government has promoted the development of nuclear power as part of its effort to reduce national dependence on oil imports, but has seen program implementation delayed by economic problems and by local opposition to the siting of nuclear power plants. At the end of 1982, the National Energy Plan called for a nuclear capacity of 11.5 GWe by 1987. In 1983, the new Socialist government announced their intention to reduce this goal to no more than 7.5 GWe by 1990, and cancelled earlier plans to develop domestic fuel recycle capability, including reprocessing. Current plans are to dispose of LWR spent fuels in a geologic repository constructed in a salt or granite formation. Interim storage needs are to be met with an AFR dry-storage facility located at the site selected for the repository. Foreign reprocessors have handled spent fuel from Spain's GCR.

Spain has an $11.1 \%$ interest in the international EURODIF enrichment plant, located in France, and a 200-t/yr fuel fabrication plant.

Nuclear activities in Spain are controlled by government through the Nuclear Energy Agency (JEN), now primarily an R\&D organization; EMPRESA, a fuel cycle services company; the Nuclear Safety Council, safety and licensing; and ENRESA, a new company formed to handle the transport and storage of spent fuel. 
Nuclear Power Projections

\begin{tabular}{|c|c|c|c|c|c|}
\hline & 1980 & 1985 & 1990 & 1995 & 2000 \\
\hline \multicolumn{6}{|c|}{ Capacity, GWe $(2,3)$} \\
\hline GCR & 0.48 & 0.48 & 0.48 & 0.48 & 0.48 \\
\hline LWR & 0.6 & 5.0 & 7.0 & 7.9 & 9.7 \\
\hline \multicolumn{6}{|c|}{ Spent Fuel Arisings (LWR) (a) } \\
\hline Annual & 18 & 135 & 190 & 210 & 260 \\
\hline Cumulative & 175 & 490 & 1,300 & 2,300 & 3,400 \\
\hline
\end{tabular}

Reprocessing Activities

Junta de Energía Nuclear (JEN) operated a small fuel reprocessing plant at the Juan Vigon Center for a few years to reprocess spent MTR fuels and was planning to build a 1-2 t/yr pilot plant at the Soria Center until the policy of the government changed in 1983.

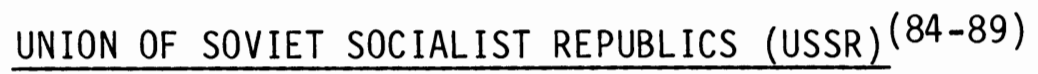

The USSR and its partners in the Council for Mutual Economic Assistance (CMEA) have joined in a cooperative program to develop a strong, selfsufficient nuclear industry with capability to build nuclear power plants and provide complete fuel cycle services. Russia's complex of nuclear power stations includes two models of LGR (1ight-water cooled, graphite-moderated), the early one fueled with uranium metal and an advanced model fueled with uranium oxide; PWRs of various sizes; and demonstration LMFBRs. Most CMEA nations (Bulgaria, Cuba, Czechoslovakia, East Germany, Hungary and Poland) and Finiand have chosen to install Russian-developed PWRs. Yugoslavia is operating a 615-MWe PWR supplied by Westinghouse and Rumania has turned to Canada for reactor technology and is installing a generation of HWRs.

The USSR controls most of the nuclear fuel cycle for the CMEA group, providing uranium enrichment, fuel fabrication and spent fuel management services for nuclear plant customers. Spent fuel is returned to Russia following

(a) Data obtained from Reference 7 , modified by PNL to reflect current power station construction schedules. 
interim storage at the reactor sites. Plans for the future call for construction in Russia of facilities for AFR fuel storage, reprocessing (for plutonium recycle to USSR FBRs), HLW vitrification, and geologic disposal of HLW glass canisters. The USSR is seeking to buy dry fuel storage casks and technology from West Germany.

Nuclear Power Projections

\begin{tabular}{|c|c|c|c|}
\hline & 1980 & 1985 & 1990 \\
\hline \multicolumn{4}{|l|}{ Capacity, USSR (GWe) (3) } \\
\hline LGR (Metal fuels) & 0.9 & 0.9 & 0.9 \\
\hline LGR (0xide fuels) & 8.0 & 16.0 & 31.9 \\
\hline PWR & 3.1 & 8.9 & 39.9 \\
\hline FBR & 1.0 & 1.0 & 1.0 \\
\hline \multicolumn{4}{|c|}{ Spent Fuel Arisings (tHM) (a) } \\
\hline \multicolumn{4}{|l|}{ Annual } \\
\hline LGR (Metal fuels) & 50 & 50 & 50 \\
\hline LGR (0xide fuels) & 360 & 920 & 1400 \\
\hline PWR & 95 & 260 & 4500 \\
\hline \multicolumn{4}{|l|}{ Cumulative } \\
\hline LGR (Metal fuels) & 1,000 & 1,200 & 1,500 \\
\hline LGR (0xide fuels) & 1,200 & 3,800 & 7,400 \\
\hline PWR & 600 & 1,600 & 3,700 \\
\hline
\end{tabular}

Projections of Spent Fuel Arisings--USSR Fuel Services Customers (b)

$1980 \quad 1985 \quad 1990$

Spent Fuel Arişipgs,

USSR Cus tomers $(a)$-.-

PWR ( $t H M)$

$370 \quad 1,100 \quad 2,900$

Annual

100

210

420

Cumulative

$390 \quad 1,295 \quad 3,140$

\footnotetext{
(a) Estimated by PNL from current projections of nuclear power capacity.

(b) The following countries have purchased PWRs and associated fuel cycle services from the USSR: Bulgaria, Cuba, Czechoslovakia, the German Democratic Republic, Hungary, Poland and Finland.
} 
Spent Fuel Reprocessing

The USSR has been reprocessing military fuels for many years, but has not yet built a reprocessing plant for commercial spent fuels. A $3 \mathrm{~kg} \mathrm{U} /$ day pilot plant for LWR and FBR fuels began operation in 1973, and authorities reportedly planned to have a 5-tU/day commercial pilot plant on-line by 1980 . The plans for commercial reprocessing have apparently been deferred considerably, probable because of delays in breeder reactor development and hence a deferred need for plutonium to fuel their breeders. The Soviets are believed to have reprocessing technology virtually identical to that used in the West. It has been reported the Soviet Union has a small dry reprocessing facility at Dimitrovgrad operating on spent fuel from the BOR-60 experimental breeder reactor. A larger version is under construction.

Waste management R\&D covers a wide field: removal of actinides from waste streams, HLW vitrification, conditioning of other wastes, treatment of plant offgases, and waste disposal by liquid injection into underground formations or by emplacement of solid wastes in deep geologic formations.

UNITED KINGDOM (UK) $^{(49,90-95)}$

The United Kingdom has developed its nuclear generating capacity around gas-cooled reactor technology for three decades. Calder Hall, the world's first commercial-sized nuclear power station, was opened in 1956. Through 1982, 21 similar gas-cooled reactor (GCR) plants and nine advanced gas-cooled reactor (AGR) plants have been added, with six more AGRs under construction. Discussions are now under way on a proposal to introduce the pressurized water reactor (PWR) system into the UK. The United Kingdom has also aggressively pursued the development of the fast breeder reactor (FBR). The 250-MWe Prototype Fast Reactor (PFR) has been operated since 1976 at Dounreay, Scotland, and has used plutonium recycled from the associated fuel reprocessing facility.

Spent fuel and waste management strategy calls for reprocessing as rapidly as plant capacity permits, (a) vitrification of HLW in a French-technology

(a) It has been reported recently that BNFL is considering abandoning plans to reprocess the UK's oxide fuels, on the basis that they can be stored for long periods and that at the present time, interim storage and direct disposal are more economical than reprocessing. (95) 
plant, long-term interim storage of HLW glass, and shallow-land burial or sea dumping of LLW and ILW. Authorities expect to build a repository at some time, but have decided that this is not an urgent matter for the UK.

The UK fuel cycle/waste management organization is quite complex: the UKAEA is in general responsible for nuclear research; the Department of the Environment has the charter for developing waste management strategy and for coordinating waste management R\&D; BNFL handles the commercial fuel cycle for the British nuclear utilities and for foreign customers; and a new organization, NIREX, attends to the disposal of LLW and ILW. These organizations are supported by a variety of regulatory, safety and research agencies.

Nuclear Power Projections

Capacity, GWe (2)

GCR (Metal fuels)

AGR (0xide fuels)

4.14 .1

$2.1 \quad 5.8$

1.6

8.2

8.2

8.2

PWR

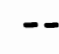

1.2

2.4

5.1

Spent Fuel Arisings (tHM)(a)

Annual

GCR

AGR

PWR

1,200

80

1,200

2,500

190

270

270

270

Cumulative

GCR ,

AGR

PWR

--

$-$

$--$

60

130

\section{Fuel Cycle Policy}

The United Kingdom has an extensive commercial fuel cycle program, based on the concept of recovering plutonium for recycle to an LMFBR system or to other uses. Either directly or through subsidiaries, BNFL is involved in

(a) Data obtained from Reference 7 , modified by PNL to reflect current power station construction schedules. 
uranium conversion and enrichment, uranium fuel fabrication, reprocessing of domestic and foreign fuels, and transport of spent fuels from reactors to the UK reprocessing plant.

Reprocessing Activities

Through its nuclear weapons program, the United Kingdom has been reprocessing spent fuel since 1952. To date, four spent fuel reprocessing plants have been built and operated: two large plants at Sellafield (formerly designated Windscale) for military and GCR fuels and two small plants at Dounreay, on the northern coast of Scotland, for FBR fuels. A head-end plant for oxide fuels clad in stainless steel or Zircaloy was added to the Sellafield complex and operated briefly in the early 1970s, and a new facility for oxide fuels (THORP) is under construction, to fulfill BNFL's commitments to foreign customers and to treat the UK's AGR and PWR oxide fuels. Through 1980, the Sellafield plants had reprocessed about 20,000 tonnes of Magnox fuel from Britain's GCRs.(49)

So far as was practical, UK reprocessing plants have been designed to allow operation of the highly radioactive sections of the plant for many years without maintenance. This has meant providing redundant process lines; placing equipment with moving parts outside the biological shield, with high-integrity drives through the shield; and placing other sections of the plant in shielded areas external to the main structure where they could be decontaminated quickly and were then accessible for direct maintenance.

\section{Butex Plant}

The first UK plant (B204) was built primarily to provide plutonium for the defense effort. The process, developed initially by an Anglo-Canadian team at Chalk River, Canada, used mechanical decladding of fuel under water, continuous dissolution of the uranium metal in nitric acid, and solvent extraction in packed columns with dibutyl carbitol (Butex) as the solvent. The plant operated successfully from 1952 to 1964, with high availability, and with major mechanical problems only with the decanning facility. 
As plans for Britain's AGR (oxide fuel) power system developed, and as it became evident that a market for commercial reprocessing services for foreign LWR oxide fuels would grow, a new head-end cell was added to the Butex Plant. This contained a shear with incremental feed of whole fuel elements, and a rotating chute which carried the cut fuel to either of two new batch dissolvers. With the fuel dropped into hot acid as it was sheared, the oxide was dissolved rapidly and the overall rate was thus controlled by the rate of shearing. The Butex Plant piping was modified to allow the co-extraction of uranium and plutonium in the primary extraction/scrub column and the stripping in the former uranium stripping column. Butex was still used as the solvent. Provision was also made to transfer the $\mathrm{Pu} / \mathrm{U}$ product stream to the Magnox Plant for partitioning and further purification of the products. The new Butex headend facility, commissioned in 1968, had a nominal capacity of $1.5 \mathrm{t} /$ day. It operated for four campaigns during the period 1969-1973, treating 90 tU of oxide fuels, mostly from foreign LWRs and was then closed as a result of an incident that released ${ }^{106} \mathrm{Ru}$ into the operating area. Various safety and other modifications to the plant were recommended at the official inquiry into this incident and have now been completed. Current plans are for two oxide fuel campaigns a year after 1985.

\section{Magnox Plant}

The second UK reprocessing plant, the Magnox Plant, started operation at Sellafield in 1964. This plant was also designed for mechanical decladding of Magnox fuel elements, and continuous dissolution, but with a Purex process solvent extraction system and mixer-settler contactors.

The Magnox Plant was designed in accordance with the philosophy applied in the Butex Plant, with these changes:

1. Duplication of equipment was confined to the highly radioactive sections, with only a single line of medium- and low-activity equipment.

2. Lift and force ejectors were used for liquid transfers, rather than multistage vacuum lifts, in the highly radioactive areas of the plant, and pumps and valves were installed in the rest of the plant. 
3. An extensive plant washdown system was installed to assist in decontamination.

4. With mixer-settlers in the solvent-extraction system, their mechanical drives were located outside the biological shielding.

5. Extensive use was made of in-line instrumentation and data processing equipment for routine logging of instrument readings.

The Magnox Plant was designed for a throughput of $5 \mathrm{t} /$ day uranium. This capacity was achieved soon after startup, and it was shown subsequently that performance could be sustained at a rate of $7 \mathrm{t} /$ day. The limiting factor on long-term throughput proved to be the rate of decanning, an operation carried out in dry facilities rather than under water, and the current Magnox Plant capacity is considered to be only $1200 \mathrm{t} / \mathrm{yr}$. BNFL plans to refurbish the decanning equipment and achieve a 1600-t/yr capacity by 1983.

The general mechanical performance of the plant has been good. For most of the plant, vessel integrity has been maintained and maintenance has been largely routine. The two areas where corrosion has been significant are in the intermediate-level waste evaporators and in the dissolver. Life of the evaporators has been limited to 5-7 years, and the first dissolver, in sole use since plant startup, was withdrawn from service in 1979.

Thermal Oxide Reprocessing Plant (THORP)

Following a 100-day Public Inquiry and subsequent debate in Parliament, the British Government in 1978 approved construction of THORP at Sellafield and set a target date of 1987 for startup. The plant complex is to include a 1000-tU spent fuel storage pond complex for LWR and AGR fuels, a reprocessing plant, and fuel receiving/handling and waste treatment facilities. The plant is designed to handle spent fuel of up to $40,000 \mathrm{MWd} / \mathrm{t}$ burnup through a single operating line with a nominal capacity of $600 \mathrm{tU} / \mathrm{yr}$.

In concept, the plant follows the principles established previously for Magnox and oxide reprocessing. Apart from the fuel chopping operation, the high-activity sections of the plant will be built to high-integrity, no-maintenance standards, and moving equipment will be avoided as far as possible. Whole elements will be sheared, using an advanced model of a replaceable shear 
pack tested in the head-end plant. The remainder of the plant will include a batch dissolver, pulsed columns for high-activity solvent-extraction operations, mixer-settlers for uranium purification, uranium (IV) as the reductant for plutonium, and a TBP-hydrocarbon solvent.

For plutonium finishing, an oxalate precipitation and calcination will produce an oxide product.

Present production commitments for THORP total $6000 \mathrm{tU}$ : $3000 \mathrm{tU}$ for the UK Electricity Generating Boards; 1600 tU for Japan; and 1400 tU for other customers. Reprocessing contracts have been negotiated on the basis that 1) each customer bears a share of the costs of capital and operating costs in proportion to the quantity of fuel covered by his contract and 2) non-UK customers take back the radioactive wastes associated with their spent fueis.

Dounreay Fast Reactor Reprocessing Plant

The UK is continuing a major effort to develop and demonstrate the fast reactor fuel cycle. The program includes reprocessing R\&D at Dounreay and Harwel1; operation of a small FBR fuel reprocessing plant at Dounreay, which treats spent fuel for the Prototype Fast Reactor (PFR) at Dounreay; and fabrication of new PFR fuel from recycled plutonium, at the Sellafield MOX fuel fabrication plant.

Reprocessing of spent FBR fuel was first accomplished in the UK in the Dounreay Fast Reactor (DFR) reprocessing plant, a small facility commissioned in 1959. The pilot plant operated in an advanced demonstration phase from 1961-1975. The flowsheet and plant were designed initially to process fuel consisting of uranium metal (40\% U-235) alloyed with $0.5 \%$ chromium, irradiated for $8800 \mathrm{MWd} / \mathrm{t}$ and cooled for 120 days after discharge. As experience was gained with the DFR and the reprocessing plant, the fuel composition was changed to $75 \% 235 \mathrm{U}$ with $7 \%$ molybdenum; fuel exposure levels were changed to $25,000 \mathrm{MWd} / \mathrm{t}$; and cooling times were reduced to 90 days.

A PUREX flowsheet, using rectangular, air-pulsed mixer-settlers, was adopted. Testing of a number of solvent compositions led to adoption of $6 \%$ TBP and a dilute $\mathrm{H}_{2} \mathrm{SO}_{4} / \mathrm{HNO}_{3}$ strip solution for the first cycle. 
After being taken out of service in 1975, the reprocessing plant at Dounreay was decontaminated and a new mechanical headend was added for plutonium-containing oxide fuels from the 250-MWe PFR, which yields about $6 \mathrm{t} / \mathrm{yr}$ spent fuel. Startup occurred in 1980. The PFR fuel reprocessing plant has a design throughput of about 5 t/yr of 8 to 10\% burnup fuel, after 230-365 days cooling. The process includes the following operations:

a. Fuel subassembly end pieces are cut off with a laser in shielded cells at the reactor site. The subassembly is then steam-cleaned to remove residual sodium and transferred to the reprocessing plant, where the end section of the wrapper is removed by laser cutting to expose the ends of the fuel pins. The pins are individually drawn from their locating grids and cropped $(2-4 \mathrm{~cm})$.

b. The oxides are dissolved in a critically-safe, thermal-recirculating tubular dissolver.

c. The feed is clarified in a critically-safe, solid-bowl, high-speed centrifuge.

d. The uranium and plutonium are decontaminated and separated by PUREXtype solvent extraction, using critically-safe mixer-settlers and a dilute $\mathrm{H}_{2} \mathrm{SO}_{4}-\mathrm{HNO}_{3}$ strip solution for Pu-U separation.

Active operation of the PFR reprocessing plant is providing much information concerning cladding and materials behavior in head-end operations, cooling requirements for irradiated subassemblies, the characteristics of solid dissolver residues, the use of a laser for fuel subassembly hardware removal, high-speed centrifugation for feed clarification, solvent degradation effects, and various solvent extraction flowsheet options.

By November 1981, $1.2 \mathrm{t}$ of spent PFR fuel had been processed with the recovery of $200 \mathrm{~kg}$ plutonium, and the plutonium was being fabricated into PFR fuel elements, for return to Dounreay during 1982. In recent years, the reprocessing plant has kept current with PFR discharges, albeit aided by the low on-stream time of the reactor. 
The plant will also be used for R\&D on the properties of dissolver residues and on the treatment of offgases from the dissolver and other pilot-plant operations.

Reprocessing R\&D

BNFL has a major test program under way in support of THORP design and operation. The program includes:

- testing of a Robatel centrifuge for feed clarification

- operation of a cold, uranium-based full-scale pilot plant which will replicate the THORP first cycle, for use in testing equipment and control instrumentation and in training operators

- operation of a hot pilot plant (1/5000th scale) to handle full-level feed and carry it through the entire head-end solvent extraction and product treatment process planned for THORP.

In addition, longer range R\&D projects have been identified: alternatives to the centrifuge for feed clarification, such as High Gradient Magnetic Separation (AEE-Winfrith); further progress toward a completely salt-free process; solvent extraction equilibrium and kinetics studies; improvements in the actinide and fission product separations processes; alternative conversion techniques for a plutonium product; improvements to the offgas and ventilation clean-up systems; and the use of power fluidics for liquid transfer and process control (AERE-Harwell and -Springfields).

Both Harwell and Dounreay have FBR spent fuel reprocessing R\&D programs. The Harwell staff is working on continuous dissolution, solvent extraction, and characterization of dissolver residues. In addition to the process studies in the PFR reprocessing plant, the Dounreay staff is investigating fuel dissolution, dissolver corrosion, feed solution filtration, solvent extraction kinetics and fluidic devices.

\section{Reprocessing Wastes}

Liquid HLW (50 l/t from Magnox fuel and $200 \mathrm{l} / \mathrm{t}$ from AGR oxide fuel) is stored in the acid form in water-cooled stainless steel tanks. BNFL has chosen 
French vitrification technology for their HLW solidification plant. An extensive research and development program on non-HLW alpha-contaminated wastes is under way.

UNITED STATES

Nuclear power stations in the United States, either operating or on order, are powered almost entirely by light-water reactors, the PWR/BWR mix approximating a ratio of 2 to 1 . The only current exceptions are the dual-purpose $\mathrm{N}$ Reactor at Hanford, graphite-moderated and water-cooled, and the Fort St. Vrain HTGR.

Current national fuel cycle policy encourages reprocessing by private industry, commits the Department of Energy to provide limited interim storage capacity for spent fuel which cannot be accommodated in reactor storage basins, and calls for the construction by the government of at least two repositories for high-level and transuranic wastes. Shallow-land burial is used universally for disposal of non-alpha-contaminated low-level wastes.

Nuclear Power Projections

\begin{tabular}{|c|c|c|c|c|c|}
\hline & 1980 & 1985 & 1990 & 1995 & 2000 \\
\hline \multicolumn{6}{|l|}{ Capacity, GWe (2) } \\
\hline LWR & 50 & 81 & 111 & 117 & 117 \\
\hline HTGR & 0.33 & 0.33 & 0.33 & 0.33 & 0.33 \\
\hline LGR & 0.86 & 0.86 & 0.86 & 0.86 & -- \\
\hline \multicolumn{6}{|c|}{$\begin{array}{l}\text { Spent Fuel Arisings } \\
\text { (LWR, tHM) }\end{array}$} \\
\hline Annual & 1,149 & 1,904 & 3,238 & 2,995 & 3,110 \\
\hline Cumulative & 6,635 & 13,811 & 27,074 & 42,000 & 57,887 \\
\hline
\end{tabular}

Fuel Cycle Activities

Current United States industrial fuel cycle activities include all phases except reprocessing: uranium mining, milling and enrichment; fabrication of $\mathrm{UO}_{2}$ and MOX fuels; interim spent fuel storage; transportation; and conditioning of reprocessing wastes. 
Spent Fuel Reprocessing (87)

The US government has been reprocessing research reactor, test reactor, and military fuels since the mid-1940s; a commercial fuel reprocessing plant operated from 1966 to 1972; and two other commercial reprocessing plants were constructed but have never been commissioned for operation.

Commercial Reprocessing

1. Nuclear Fuel Services (NFS) (96-101)

In 1962, Nuclear Fuel Services (NFS) reached an agreement with the Atomic Energy Commission (AEC) and the state of New York to construct a $300 \mathrm{t} / \mathrm{yr}$ spent nuclear fuel reprocessing $\mathrm{plant}$ in west Valley, New York. Construction was completed in 1966 and the plant was operated from 1966 to 1972, during which time about $640 \mathrm{t}$ of fuel was reprocessed. In 1972, the plant was shut down temporarily, to allow expansion to $750 \mathrm{t} / \mathrm{yr}$, to correct some deficiencies in the process, to improve environmental and personnel protection features and to install the waste treatment facilities needed to meet new regulatory requirements. In 1976, management decided against making the investment required to meet the new licensing requirements and withdrew from the reprocessing business.

The NFS plant had a chop-leach headend, a PUREX solvent extraction system with pulse-column contactors, and a batch ion exchange system for plutonium purification. It used a combination of remote and contact maintenance: the chop-leach, feed preparation and waste evaporation units were remotely maintained, while the remainder of the plant (e.g., the PUREX process cells) was contact-maintained. High-level liquid wastes, combined with low-level waste concentrates, were collected in water-cooled, steel underground tanks. 555,000 gallons of neutralized HLW from the Purex processing of uranium-base fuels are stored in a carbon-steel tank while 12,000 gallons of acidic waste from the Thorax processing of thorium-base fuels are stored in a stainless-steel tank. Treated 
overheads from the LLW concentrators were discharged to a nearby waterway. Solid wastes were buried in an adjacent shallow-land burial ground.

In 1982, the U.S. DOE assumed control of the NFS site and assigned operations to West Valley Nuclear Services (a subsidiary of Westinghouse Electric Corporation). Major activities now under way include decommissioning of the former reprocessing plant and demonstration of high-level waste vitrification using the liquid high-level wastes onsite. The liquid-fed ceramic melter process has been selected for demonstration.

2. Barnwell Nuclear Fuel Plant (BNFP) $(91,102,103)$

In 1968, Allied-Gulf Nuclear Services (AGNS) was formed by Allied Chemical and Gulf $0 i 1$ to construct the BNFP. The Barnwell construction permit was granted in 1970 and construction began in 1971, the plant being scheduled for startup in early 1974 at a nominal $5 \mathrm{t} /$ day $(1500 \mathrm{tU} / \mathrm{yr}$ ) throughput.

The BNFP incorporated a shear at the headend and chopped fuel fell into one of two dissolvers. Tributyl phosphate was used in the pulse-column solvent-extraction (PUREX) system. The process design called for the first extraction contactor to be either a Saint-Gobain centrifugal unit or a pulsed column, and the separation of plutonium was to be achieved by reducing the plutonium electrolytically in an "electropulse" column, a development of the AGNS technical staff. Maintenance was designed to be a combination of remote and direct: the chop-leach headend and HLW evaporator were fully remote; the feed preparation and first cycle extraction systems were semi-remote, while the rest of the plant was built for contact maintenance. Highlevel and intermediate-level liquid wastes were to be collected in water-cooled, stainless steel, underground tanks and no final selection of a solidification process was made. Excess water from the operations was to be vaporized and discharged to the atmosphere. cladding hulls were to be fixed in cement and stored onsite with other TRU wastes. 
After the federal policy decision in 1977 to defer indefinitely all reprocessing of commercial spent fuel, the NRC terminated its proceedings on the BNFP 1icense. In the subsequent five years, the facility was used for special R\&D studies funded by the federal government. This funding was discontinued in 0ctober 1983 and the plant is being decommissioned and the staff dispersed. Operation of the facility, if reactivated, would require heavy expenditures for plutonium conversion and HLW vitrification facilities.

3. Midwest Fuel Recovery Plant (MFRP) (104-107)

General Electric Company (G.E.) designed and constructed a $300 \mathrm{t} / \mathrm{yr}$ fuel reprocessing plant at Morris, Illinois. The original scheduled startup date for the facility was in 1972.

The Morris plant employed major departures from the typical PUREX-TBP process, with the aim of minimizing reprocessing costs. The G.E. Aquafluor process used TBP solvent extraction only for the initial cycle for separating of uranium and plutonium. The cleanup cycle used fluidized beds for calcining of uranyl nitrate to the oxide $\left(\mathrm{UO}_{3}\right)$ and for converting the oxide to the hexafluoride $\left(U_{6}\right)$. Instead of the usual second solvent-extraction cycle for the uranium, G.E. incorporated a separation step that exploited differences in volatility for separating the fluorides of the fission products from the $U_{6} \cdot$

High-level liquid wastes were to be calcined by a fluidized-bed process and the calcine product packaged for storage in a water pool. Cladding hulls were to be collected in large silos.

The HLW calcination step operated satisfactorily; however, the fluidized bed operations used for uranium conversion proved difficult. In cold testing, the equipment plugged, and the problems of handling fine radioactive powders were found to be far greater than had been anticipated. G.E. concluded in mid-1974 that the plant was not operable in its present configuration and that modifications 
requiring several years and costing in excess of $\$ 100$ million would be required for the plant to be made operable. The decision to abandon the effort was brought about by the uncertain climate which affected the other commercial reprocessing ventures in the US during the 1970s.

4. Nuclear Fuel Recovery and Recycling Center (NFRRC) $(108,109)$

During 1971-1978, Exxon Nuclear developed preliminary designs, safety analyses, an environmental report, and other documentation associated with construction of the $2100 \mathrm{tU} / \mathrm{yr}$ NFRRC to be built in Tennessee. The facility preliminary designs called for a chop-leach head end and PUREX-type solvent extraction in pulsed columns. The highly-active sections were to be remotely-maintained while the low-active sections were to be contact-maintained. High-and intermediate-level liquid wastes were to be converted to a borosilicate glass using a liquid-fed ceramic melter, possibly with a fluidized bed calciner prior to the melting step. The cylinders of waste glass were to be stored in the fuel storage pool together with the packaged hulls. All other wastes were to be packaged for onsite storage, and excess water was to be vaporized and discharged to the atmosphere. The decision by President Carter in 1977 to defer reprocessing caused Exxon Nuclear to drop further consideration of the project.

\section{Military Fuels Reprocessing}

Reprocessing plants for military fuels are located at the Hanford Site in eastern Washington, at the Idaho National Engineering Laboratory in southcentral Idaho, and at Savannah River in South Carolina. The original production fuel reprocessing facilities were built at Hanford in the 1940s. In the early 1950s, Idaho Chemical Processing Plant was designed and built specifically to reprocessing highly-enriched uranium production, test, and ship propulsion reactor fuels. The SR plants were added late in the 1950 s to process highenriched uranium fuel from production reactors. 
1. Idaho Chemical Processing Plant (ICPP) $(110-114)$

The Idaho Chemical Processing Plant is located at the U.S. DOE'S Idaho National Engineering Laboratory near Idaho Falls, Idaho. The ICPP facilities are designed to reprocess spent nuclear fuel from test and research reactors in the U.S. and foreign countries, and from the U.S. Navy's ship propulsion reactors. The ICPP began operation in 1953 and is currently equipped to process aluminum-alloyed, zirconium-alloyed, stainless-steel-based, and graphite-based fuels. The chemical reprocessing plant uses various solvent extraction, separation and purification techniques, depending upon the type of fuel being processed. The head-end facilities are equipped for mechanical disassembly (if necessary) and the co-dissolution of cladding and fuel. Pulsed and packed columns are used for purification. Because the ICPP processes highly enriched fuel, processing equipment is necessarily small (for criticality reasons). The plant was originally designed for direct maintenance and is still in operation. In subsequent modifications, more use of remote maintenance features is being made.

High-level liquid wastes and low- and intermediate-level liquid waste concentrates are stored onsite in 300,000-gallon, stainless steel tanks. The Waste Calcination Facility (WCF) began operation in 1963, using a fluidized bed process to convert the liquid wastes to a granular product which is stored onsite in large, stainless steel, underground bins. This facility, contact-maintained, was operated until 1981. It became increasingly difficult to maintain because of high exposure of personnel. A new, larger facility, with remote capability of maintaining critical components was placed in operation in 1982 .

2. Savannah River Plant (SRP) $(91,115-120)$

In the early 1950s, the U.S. AEC built two new reprocessing plants (200-F and 200-H) on the Savannah River near Aiken, South Carolina. The 200-F facility was designed for an aluminum-clad, natural U-metal fuel. The Savannah River Plant (SRP) uses a modified 
PUREX flowsheet following chemical decladding. Tributyl phosphate (TBP) was selected for the solvent extraction process. When TBP is dissolved in a kerosene-like solvent, it is chemically even more stable than butex, is cheaper than hexone, and gives better separations than either. SRP, like Hanford, was designed for remote (as opposed to direct) maintenance. Unlike Hanford, which uses pulsedcolumn contactors, the Savannah River Plant uses a centrifugal contactor (developed there) and mixer-settlers. Processing begins with dissolution of the aluminum cladding that encapsulates the metallic uranium fuel, in a sodium hydroxide--sodium nitrate solution. After the decladding operation, the fuel is dissolved in nitric acid. The initial TBP separation phase yields solutions of plutonium, uranium, or neptunium product and the high-heat-generating fission product wastes.

The 200-H facility was designed for aluminum-clad, natural uranium fuel but was modified in 1959 to recover $U$ from SR production reactor fuels. Subsequently, an electrolytic dissolver was installed for handling cermets and fuels clad with stainless steel or zirconium. Special processing programs have included recovery of thorium, $223 \mathrm{U}$, and various mixtures of plutonium isotopes.

High- and intermediate-level wastes from the reprocessing operations are neutralized and stored in large, steel, underground tanks. In 1983, construction of the Defense Waste Processing Facility (DWPF) was started. This facility will convert the sludges from the tanks into borosilicate glass. Supernates from the tanks will be treated to remove soluble cesium and other radionuclides and then fixed in cement. The recovered radionuclides will be added to the sludge for vitrification.

3. Hanford Reprocessing Plants $(121,123)$

Three types of reprocessing plants have operated at Hanford: the "bismuth phosphate" plants ( $B$ and $T$ Plants), which depended on a series of precipitation reactions to remove the plutonium from the 
dissolved fuel solution, leaving a waste containing uranium and fission products; the "Redox" plant, which used a solvent extraction process employing methyl isobutyl ketone ("hexone") as the solvent and packed columns for the contactors; and the PUREX plant, which uses the conventional PUREX process. Hanford was also the site of a solvent extraction plant ( $U$ Plant), which recovered the uranium from the large volume of stored high-level wastes from the bismuth phosphate plants.

The Hanford PUREX plant and the associated uranium oxide $\left(\mathrm{UO}_{3}\right)$ facility for converting uranyl nitrate to $U_{3}$ operated from 1956-1972 to process the irradiated fuels produced by nine Hanford plutonium production reactors. The process used chemical decladding in the headend and employed TBP dissolved in a kerosene-like hydrocarbon as the separating agent in pulsed columns.

As at the Savannah River site, high- and intermediate-level wastes from the reprocessing operations are neutralized and stored in large, steel, underground tanks. After cooling for an extended period, the wastes are evaporated, leaving a salt cake in the tanks.

By 1972, all the production reactors at Hanford, except the $\mathrm{N}$-Reactor, had been shut down. After the PUREX and $\mathrm{UO}_{3}$ facilities had processed the inventory of irradiated fuels, its continuous operation was discontinued and it was readied for standby. In the mid-1970s, DOE determined that processing of irradiated fuels from the $\mathrm{N}$-Reactor is required to meet the nation's nuclear defense and R\&D needs. (108) The plant was modified substantially to mitigate potential environmental consequences, primarily by reducing the plant emissions. Radioactive operation of the PUREX plant resumed in November 1983. The reprocessing campaign may extend to about the year 2000 .

Reprocessing R\&D

In addition to the major commercial and defense reprocessing programs in the US described, extensive R\&D, both nonradioactive and radioactive, has been 
conducted at the U.S. DOE laboratories. A major demonstration of pyrochemical reprocessing was conducted at the EBR-II facility of the Idaho National Engineering Laboratory in the early sixties. (124) Also, reprocessing of LWR fuels was a major part of the demonstration of the Nuclear Waste Vitrification Project conducted at the Hanford site in 1976-79. (125)

Current US fuel reprocessing R\&D studies are centered in the Consolidated Fuel Reprocessing Program (CFRP), which is under the direction of Oak Ridge National Laboratory and has as its principal objective the development of technology for reprocessing spent LMFBR fuels. The associated Breeder Reprocessing Engineering Test (BRET), a joint effort between Hanford Engineering Development Laboratory and Oak Ridge National Laboratory, is the major activity in the CFRP. In another phase of the CFRP, research and development activities in high-temperature gas-cooled (HTGR) fuel reprocessing technology are being conducted at General Atomic Company (GA).

\section{Reprocessing Wastes}

The U.S.A. along with most other nations using nuclear power, is planning to vitrify HLW and to dispose of the waste glass together with non-HLW alphacontaminated wastes in stable geologic formations. Candidate formations include salt, basalt, volcanic tuff, granite, shale, and mudstone.(126) Nonalpha-contaminated wastes are disposed by shallow-land burial. 


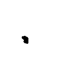




\section{REFERENCES}

1. Ford Foundation, Nuclear Power Issues and Choices, Ballinger Publishing Company, Cambridge, Massachusetts, 1977.

2. "NUKEM Market Report on the Nuclear Fuel Cycle--11/83," NUKEM GmbH, Hanau, Federal Republic of Germany.

3. "Power Reactors 1983," Nuclear Engineering International, August 1983 Supplement.

4. H. Baiviot, "Laying the Foundations for Plutonium Recycle in Light Water Reactors," Nuclear Engineering International, January 1984, pp. 27-33.

5. INFCE Summary Volume, INFCE/PC/2/9, published by International Atomic Energy Agency, Vienna, 1980, p. 70.

6. "Worldwide Spent Fuel Disposition Analys is," Nuclear Assurance Corporation, NAC Report No. C-8023, September 1980.

7. "Light Water Reactor Spent Fuel Storage and Reprocessing in Europe in the 1980s," Nuclear Assurance Corporation report prepared for U.S. DOE, December 1981.

8. AIF INF0 News Release, March 31, 1983.

9. "Spent Fuel and Radioactive Waste Inventories, Projections, and Characteristics," DOE/NE-0017/2, September 1983.

10. "Czechoslovakia Expands On-Site Storage After Considering Centralized Facility," Nuclear Fuel, October 24, 1983.

11. Energy in Countries with Planned Economics, December 1981.

12. "Hungary's First Nuclear Unit Went On-Line in January," Nuclear News, March 1983, p. 26.

13. "Romania Trying to Make Up Lost Time in Installing Nuclear Plants," Nucleonics Week, August 18, 1983.

14. "Argentina Seeks Self-Sufficiency." Nuclear Engineering International, May 1982 , p. 7 .

15. "Argentina: Bent on a Home-Grown Nuclear Program," Energy Daily, November 9, 1982.

16. J. E. Katz and 0. S. Marwah, Nuclear Power in Developing Countries, D. C. Heath and Company, publishers, 1982. 
17. D. Hart, Nuclear Power in India, George Allen and Unwin, publishers, London, 1983.

18. "Argentina Enriches Its Fuel Cycle," Nuclear Engineering International, 29(350):3-4, January 1984 .

19. "Argentina Edges Closer to the Bomb," New Scientist, September 22, 1983, p. 832.

20. Detilleux, E. and S. Coo, "Recent Eurochemic Reprocessing Experience," Proceedings of the International Conference on Constructive Uses of Atomic Energy, Washington, D.C., November 1968.

21. Baetslé, L. H., W. R. A. Goossens, R. DeBeukelaer, and J. P. Rombaux, "Technological Study of the Head-End Steps of Mixed 0xide Fuel Reprocessing." European Nuclear Conference, May 6-11, 1979, Hamburg, West Germany.

22. Detilleux, E. and E. Eschrich, "Gaining Experience in Decontamination and Waste Management at a Shut-Down Reprocessing Plant," Nuclear Engineering International, April 1978.

23. Dejonghe, P., L. Baetslé, J. Claes, R. DeBatist, R. Heremans, and N. Van de Voorde, "General Perspectives in Radioactive Waste Management in Belgium," In: Proceedings of the International Conference on New Directions in Nuclear Energy with Emphas is on the Fuel Cycle. April 26-30, 1982, Brussels, Belgium.

24. "Reopening of the Dormant Eurochemic Reprocessing Plant," Nucleonics Week, March 31, 1983.

25. "Decision on Reopening a Modernized Eurochemic Plant Slated by Mid-1984," Nuclear Fuel, October 10, 1983.

26. "Reprocessing Recruit," New Scientist, Apri1 7, 1983, p. 5.

27. "Brazil's First Production of Yellowcake Puts It on Road to Fuel Cycle Independence," Nuclear Fuel, January 4, 1982.

28. "Nuclebras President Paulo Nogueina Batista Resigned from the Post," Nucleonics Week, February 3, 1983.

29. Rummery, T. E., D. Lisle, J. Howieson and D. H. Charlesworth. "Radioactive Waste Management Policy and Its Implementation in Canada," IAEA-CN-43/165, IAEA International Conference on Radioactive Waste Management, Seattle, Washington, May 1983.

30. "China Plans to Build Two More Nuclear Power Plants Between 1986 and 1990," Nucleonics Week, March 29, 1984. 
31. "NUKEM Market Report on the Nuclear Fuel Cycle--Special Report, France," October 1978.

32. "La Hague Expansion a Certainty Despite Ruminations Over Spent Fuel Policy," Nucleonics Week, January 20, 1983.

33. Megy, J. "Reprocessing Spent Fuel in France." Nuclear Engineering International, March 1983, pp. 40-42.

34. "Reprocessing Prospects," Nuclear News, July 1983, p. 60.

35. "French Report Supports Reprocessing," Nuclear News, February 1983, p. 104 .

36. "Report of the Working Group on the Management of Irradiated Fuels," Ministry of Research and Industry, France, November 1982 (translation available from DOE Technical Information Center, Oak Ridge, Tennessee).

37. "U.S. Department of Energy Comments on the Paper Entitled 'Bubble, Bubble, Toil and Trouble; Reprocessing Nuclear Spent Fuel, '" DOE/NE-0049, March 1983, Attachments B \& C.

38. "How France Went Nuclear," New Scientist, January 1983, pp. 84-86.

39. "Cogema Interprets Its Reprocessing Contracts," Nuclear Fuel, December 5, 1983, p. 11.

40. De L'Estang, F. Bujon. "Financing of the La Hague UP3 Reprocessing Plant," Proceedings of the ANS Topical Meeting on the Financial and Economic Bases for Nuclear Power, Washington, D.C., Apri1 8-11, 1984.

41. Sauteron, J., M. Bourgeois, J. Couture, and P. Roblin. 1978. "Technologie Du Retraitement Des Combustibles Des Reacteurs Rapides," IAEA-CN-36/567 Translation: Technology of Reprocessing Fast-Reactor Fuel, appeared as BNWL-TR-336, July 1978.

42. Sauteron, J., "France Pushes Forward with FBR Fuel Reprocessing," Nuclear Engineering International, November 1983, p. 38.

43. "France Stays Course on FBR Reprocessing While Outlook Dims for Reactor Orders," Nuclear Fuel, June 6, 1983, p. 14.

44. "The TOR Facility: Closing the FBR Fuel Cycle," Nuclear News, June 1983, pp. 106-108.

45. "Management and Disposal of Used Nuclear Fuel and Reprocessing Wastes," The Uranium Institute, New Zeal and House, Haymarket, London, 1983.

46. "La Hague Had a Good Year in 0xide Reprocessing," Nuclear News, December $1983, p .130$. 
47. "France and USSR Consider Experimental Dry Reprocessing for Breeder Fuel," Nuclear Fuel, June 4, 1984, p. 14.

48. Schüller, W. et al, "Fuel Reprocessing and Waste Treatment at Karlsruhe Nuclear Research Centre," in Proceedings of IAEA International Conference on Nuclear Power and Its Fuel Cycle. IAEA-CN-36/571, Salzburg, Austria, May 2-13, Vo1. 3, pp. 579-592, 1977.

49. Zühlke, P. (WAK), "Facts and Trends in European Nuclear Fuel Reprocessing," presented at International Conference on the Nuclear Fuel Cycle, Amsterdam, Netherlands, September 14-17, 1980.

50. "WAK Back on Stream," ATW News, December 1982.

51. Nuclear Fuel, May 10, 1982.

52. "WAK's Back," Nuclear Energy International, December 1982, p. 13.

53. "Testing Reprocessing Components at Full Scale," Nuclear Engineering International, May 1983, p. 23.

54. Nuclear News, July 1983, p. 60.

55. "Wackersdorf WA-350 Project in the Licensing Phase," ATW News, February 1983.

56. "Peak Burnup Breeder Fuel Reprocessed," ATW News, August 1983.

57. Merz, E. R., "The Thorium Fuel Cycle," in Proceedings of the IAEA International Conference on Nuclear Power and Its Fuel Cycle, IAEA-CN-36/96, Salzburg, Austria, May 2-13, Vol. 2, pp. 37-53, 1977.

58. Kaiser, G., E. Merz, E. Zimmer, H. Pirk, and P. Vygen, "Reprocessing Technology in the HTGR Fuel Cycle," in Proceedings of the IAEA International Conference on Nuclear Power and Its Fuel Cycle, IAEA-CN-36/112, Salzburg, Austria, May 2-13, 1977, Vo1. 3, pp. 661-671, 1977.

59. "German Reprocessing Plant Site Choice Due Soon," Nuclear News, February $1984,22(2): 58$.

60. J. Mischke and K. Hendrich, "Remote Maintenance Concept of the DWK Spent Fuel Reprocessing Plant," Proceedings of the 1984 ANS National Topical Meeting on Robotics and Remote Handling in Hostile Environments, Gatlinburg, Tennessee, April 24-27, 1984.

61. J. Mischke and P. Leister, "DWK Test Facility for Remote Maintenance: First Results of Test Program," Proceedings of the 1984 ANS National Topical Meeting on Robotics and Remote Handling in Hostile Environments, Gatlinburg, Tennessee, Apri1 24-27, 1984. 
62. NUKEM Market Report on the Nuclear Fuel Cycle, April 1983, p. 7.

63. "Five Nations Mark Major Nuclear Advances in 1982," Atomic Industrial Forum, INF0 News Release, March 31, 1983.

64. Nuclear News, February 1981, pp. 64-66.

65. H. N. Sethna and S. N. Svimivasan, "Operating Experience with the Fuel Reprocessing Plant of Trombay," AIChE Symposium Series 94, Vo1. 65, pp. 20-25, 1965.

66. A. N. Prasad and S. V. Kunar, "Fuel Reprocessing Experience in India," Proceedings of an IAEA International Conference on Nuclear Power Experience, Vienna, Austria, September 13-17, 1982, Vo1. III, pp. 831-838.

67. Proceedings of the Joint Israel-U.S. Meeting on Safety and Siting Problems of Nuclear Power Reactors in a Small Country, held December 10-22, 1983 at Haifa, Is rael. Available from Department of Nuclear Engineering, Israel Institute of Technology, Haifa, Israel.

68. "Energy Policies and Progammes of IAEA Countries," OECD/International Energy Agency, Paris, a Review, 1980.

69. Moccia, A., S. Cao, M. Abita, G. M. Gasparini and G. Grossi, "The Search for Alternate Fuel Recycling Technologies in LWR-FBR Systems," paper presented at the Second ENC - Hamburg, May 6-11, 1979 (1978).

70. G. Calleri, M. Fiorelli, and G. Grossi, "Problems Encountered During the Construction of the Eurex Plant," AIChE Symposium Series 94, Vol. 65, pp. 33-52, 1965 .

71. "Japan's Strategy for Plutonium Uses," Atomic in Japan, October 1982, pp. $12-15$.

72. Nakajima, K., "Status and Plan of Spent Fuel Reprocessing in Japan," paper presented at the Joint Atomic Industrial Forum, Dutch Atomic Forum International Conference on the Nuclear Fuel Cycle, September 14-17, 1980.

73. "Tokai-mura to Produce Non-Weapon Plutonium," Japan Times, March 13, 1983.

74. Nakajima, K., "Present Status and Prospects of Reprocessing," in Proceedings of the International Conference on New Directions in Nuclear Energy with Emphasis on the Fuel Cycle, April 26-30, 1982, Brussels, Belgium.

75. "Japan's Pilot Spent-Fuel Reprocessing Plant Has Started Up," Nucleonics Week, December 8, 1983. 
76. "Britain and France Wi11 Equal1y Split Reprocessing of 3270 Metric Tons," Nucleonics Week, October 28, 1976.

77. "Joyo Fuel Reprocessing Begins," Nuclear Engineering International, December 1982, p. 6.

78. "A Frustrating Wait for Mexico's Nuclear Power Planners May Be Over," Nucleonics Week, November 6, 1980.

79. "Pakistan's AEC Plans to Set Up More Nuclear Plants 'At a Much Faster Rate, '" Nucleonics Week, October 4, 1979.

80. "Pakistan's Budget for 1983-84 Earmarks $\$ 30$ Million for the Chashma Nuclear Power Project," Nucleonics Week, June 16, 1983.

81. "Nuclear Policy," NUKEM Market Report on the Nuclear Fuel Cycle, September 1983, p. 7 .

82. Benito, Antonio Sevilla, "Activities of the JEN-Prevent Programmes and Objectives," Nuclear Engineering International, February 1977, p. 52-57.

83. "Spent Fuel Management," NUKEM Market Report on the Nuclear Fuel Cycle, November 1983, p. 7 .

84. "The Soviet Share of COMECON Nuclear Power Manufacturing Has Dropped to $50 \%, "$ Nucleonics Week, March 24, 1983.

85. Semenov, B. A., "Nuclear Power in the Soviet Union," IAEA Bulletin, Vol. 25, No. 2, June 1983, pp. 47-59.

86. "Soviet Preference for Dry Storage Seen in Recent Order of German Cask," Nuclear Fuel, September 12, 1983.

87. Dubrovsky, V. M. et a1., "The USSR Experience in Nuclear Power PIant Spent Fuel Handling Including Storage and Transportation," IAEA-CN-42/88, included in Proceedings, International Conference on Nuclear Power Experience, International Atomic Energy Agency, Vienna, September 1982.

88. "Soviet Turning to Spent Fuel Storage as Breeder Slowdown Delays Reprocessing," Nuclear Fuel, September 27, 1982, p. 15.

89. S. Rippon, "Nuclear Power Growth in the Soviet Union," Nuclear News, February 1984, $27(2): 62-66$.

90. Tatlock, J., L. P. Shortis and N. R. Geary, "Reprocessing in the United Kingdom," presented at Fuel Cycles for the '80's Symposium, Gatlinburg, Tennessee, September 30, 1983.

91. Bebbington, W. P., "The Reprocessing of Nuclear Fuels," Scientific American, Vol. 235, №. 6, pp. 30-41, 1976. 
92. Aycoberry, C. and P. Zühlke, "Present Status and Prospect of Reprocessing," in Proceedings of the International Conference on New Direction in Nuclear Energy with Emphasis on the Fuel Cycle, April 26-30, Brussels, Belgium, 1982 .

93. Allardice, R. H. and H. A. Taylor, "Plutonium Processing for the Fast Reactor Fuel Cycle," Nuclear Engineering International, November 1979.

94. "Closing the Fast Fuel Cycle," Nuclear Energy International, November 1981.

95. "Britain is Set to Abandon Nuclear Reprocessing," New Scientist, March 3, 1983 , p. 48.

96. T. L. Cramer, "NFS: First Fuel Reprocessor," Nucleonics, 24(12):48-52, December 1966.

97. Rochlin, G. I., M. Held, B. G. Kaplan, and L. Kruger, "West Valley: Remnant of the AEC," Bulletin of the Atomic Scientists, January 1978, pp. $17-26$.

98. L. A. Abrams, "Fuel Reprocessing-Commercial Experience," Reactor and Fuel Processing Technology, 12(2):181-194, Spring 1969.

99. J. R. Clark, "Modifying the West Valley Reprocessing Plant," Nuclear Engineering International, February 1976, pp. 27-31.

100. R. C. Mairson, "Nuclear Waste Management: The West Valley Project," presented at the AIF Fuel Cycle Conference '83, Kansas City, Missouri, March 20-23, 1983.

101. Hamric, J. P., "West Valley Demonstration Project Strategy for an Achievable But Challenging Project," in The Treatment and Handling of Radioactive Wastes, Proceedings of an ANS Topical Meeting, April 19-22, 1982, Richland, Washington.

102. R. I. Newman, "The Barnwell Nuclear Fuel Plant," Nuclear Engineering International, 17(198):938-941, November 1972.

103. A. L. Ayers and G. K. Hovey, "The Allied-General Nuclear Services Plant-A Minimum Maintenance Facility," Proceedings of the 24th Conference on Remote Systems Technology, 1976, held in conjunction with ANS Winter Meeting, November 15-19, 1976, Washington, D.C., pp. 101-109.

104. "Midwest Reprocessing Plant," Nuclear Engineering International, 17 (193):481-482, June 1972 .

105. A. B. Carson, B. F. Judson, S. Levy, and J. E. Van Hoomisson, "Fuel Reprocessing--A General Electric View," presented at Sixth Annual Conference of Japan Atomic Industrial Forum, Tokyo, Japan, March 7-9, 1973. 
106. R. G. Barnes, B. F. Jundson, R. N. Robinson, and N. P. Sharkh, "High Level Radioactive Waste Management at the Midwest Fuel Recovery Plant," Waste Management ' 74 .

107. "Midwest Fuel Recovery Plant Technical Study Report," General Electric Company, USAEC Docket No. 50-268, July 5, 1974.

108. G. L. Ritter, "The Exxon Nuclear Fuel Recovery and Recycling Center: Process Description," Nuclear Technology, 43(2):194-202, April 1979.

109. J. E. Birchler and H. C. Caudill, "Exxon Nuclear Fuel Recovery and Recycling Center: Facility Description," Nuclear Technology, 43(2):203-212, Apri1 1979.

110. R. B. Lemon and D. G. Reid, "Experience with a Direct Maintenance Radiochemical Processing Plant," Proceedings of the International Conference on the Peaceful Uses of Atomic Energy held August 8-20, 1955 at Geneva, Vo1. 9, pp. 532-545.

111. Final Governmental Impact Statement, Waste Management Operations, Idaho National Engineering Laboratory, Idaho, ERDA-1536, September 1977 , p. II -56 - I I-102.

112. G. E. Bingham and B. R. Wheeler, "The New Waste Calcining Facility," Proceedings of the 24th Conference on Remote Systems Technology, Washington, D.C., November 15-19, 1976, pp. 43-49.

113. D. M. Paige, L. A. Decker, and D. E. Black, "Remote Systems for the Zirconium Pressurized Water Fuel Dissolution Process at the Idaho Chemical Processing Plant," Proceedings of the 25 th Conference on Remote Systems Technology, ANS, 1977. ISN:0069-8644, pp. 177-185.

114. J. R. Berreth and B. R. Dickey, "High-Level Waste Management at the Idaho Chemical Processing Plant," Proceedings of the ANS Topical Meeting on the Treatment and Handling of Radioactive Waste held at Richland, Washington, April 19-22, 1982, pp. 449-454.

115. "Waste Management Operations--Savannah River Power Plant-FEIS," ERDA-1537, ERDA 1977 , p. 22.

116. J. L. Schwennssen, "A Survey of Design and Operating Practices for Nuclear Fuel Processing Plants," Proceedings of the Second International Conference on the Peaceful Uses of Atomic Energy, held at Geneva, Switzerland, September 7-13, 1958, Vo 1. 17, pp. 514-530.

117. E. B. Sheldon, "Experience with Processing Irradiated Fuel at the Savannah River Plant (1954-1976), DP-1467, September 1977.

118. J. M. McKibben, J. B. Starks, and S. K. Brown, "The Savannah River Plant Purex Plant--25 Years of Successful Remote Operation," Proceedings of the 27 th Conference on Remote Systems Technology, ANS, 1979. 
119. Final Environmental Impact Statement, Waste Management Operations, Savannah River Plant, Aiken, South Carolina, ERDA-1537, September 1977, pp. II-1 - II-191.

120. R. Maher, L. F. Shafranek, J. A. Kelley, R. W. Zeyfang, and A. J. Letheo, "The Defense Waste Processing Facility: A Remote Process for Solidification of Savannah River Plant High Level Waste," Proceedings of the ANS Topical Meeting on the Treatment and Handling of Radioactive Waste, held at Richland, Washington, April 19-22, 1982, pp. 431-440.

121. Final Environmental Statement, Waste Management Operations, Hanford Reservation, Richland, Washington, ERDA-1538, December 1975, Vol. 2, pp. I I.1-C.3 - I I.1-C.84.

122. B. F. Campbe11, E. Doud, and R. E. Tomlinson, "Current Practice in the Management of High-Level Radioactive Wastes in the United States of America," IAEA, 1963.

123. DOE, Draft EIS--Operation of Purex and Uranium 0xide Plant Facilities, Hanford Site, DOE/EIS-0089D, Washington, D.C., 1982.

124. C. C. Stevenson, M. J. Feldman, D. C. Hampson, D. M. Paige, and N. J. Swenson, "Operation of a Pyrochemical Processing--Remote Fabrication Plant: The EBR-II Fuel Cycle Facility," AIChE Symposium Series 94, Vol. 65, pp. 61-69, 1965.

125. E. J. Wheelwright, W. J. Bjorklund, L. M. Browne, G. H. Bryan, L. K. Holfon, E. R. Irish, and D. H. Siemens, "Generation and Vitrification of High-Level Light Water Reactor Liquid Waste," Nuclear Technology, Vol. 58, pp. 271-293, August 1982.

126. Draper, E. L., "Nuclear Waste Management in the United States," in Proceedings of the International Conference on New Direction in Nuclear Energy with Emphasis on the Fuel Cycle, April 26-30, 1982, Brussels, Belgium.

127. J. T. Long, Engineering for Nuclear Fuel Reprocessing, Gordon and Breach Science, publishers, New York, 1967.

128. "Reprocessing, Plutonium Handling, Recycle," report of Working Group 4, INFCE/PC/2/4, published by International Atomic Energy Agency, Vienna, 1980 .

129. "Waste Management and Disposal," report of Working Group 7, INFCE/PC/2/7, published by IAEA, Vienna, 1980, p. 38. 

APPENDIX A

REPROCESSING TECHNOLOGY 

APPENDIX A

\section{REPROCESSING TECHNOLOGY}

Reference 127 provides general background on nuclear fuel reprocessing and a reprocessing plant for LWR oxide fuels is described in Reference 128. As shown in Figures $A .1$ and $A .2$ (simplified flow diagram and reference plant layout), spent fuel elements are moved from the interim storage facility to the head-end plant, where the excess hardware and cladding are removed and the fuel is dissolved in nitric acid. In nearly all LWR fuel reprocessing plants, the so-called "chop-leach" process is employed, in which the fuel pins or assemblies are cut into short segments by a shear and the $\mathrm{UO}_{2}$ is dissolved away from the cladding hulls. The hulls and other hardware are treated as waste, while the uranium and plutonium in the dissolver solution are separated from each other and from the fission products by a liquid-liquid extraction process. In this multicycle extraction process, developed originally for defense fuels, the uranium and plutonium are first separated from most of the highly active fission products by extraction from the nitric acid feed stream into an organic solvent, generally $30 \%$ tributyl phosphate (TBP) in a kerosene-type diluent. The plutonium and uranium are then removed from the organic solvent and further purified and separated from each other in subsequent extraction cycles. The plutonium and uranium are further purified and concentrated. Ion exchange is sometimes used in lieu of solvent extraction for the final purification and extraction steps. The resulting uranyl and plutonium nitrate products are then passed to buffer storage tanks prior to transfer to conversion facilities. Pulsed columns, mixer settlers, and centrifugal contactors are the three types of solvent extraction contactors most frequently used.

A fundamental issue in the design of reprocessing plants is the selection of a plant maintenance philosophy. In some plants, all equipment in which radioactive materials are handled is installed in such a way that each piece of equipment can be remotely removed for maintenance or repair. This is referred to as the "canyon" concept or design. Other plants are designed, perhaps with duplication of equipment, to give high reliability over long periods of time. 


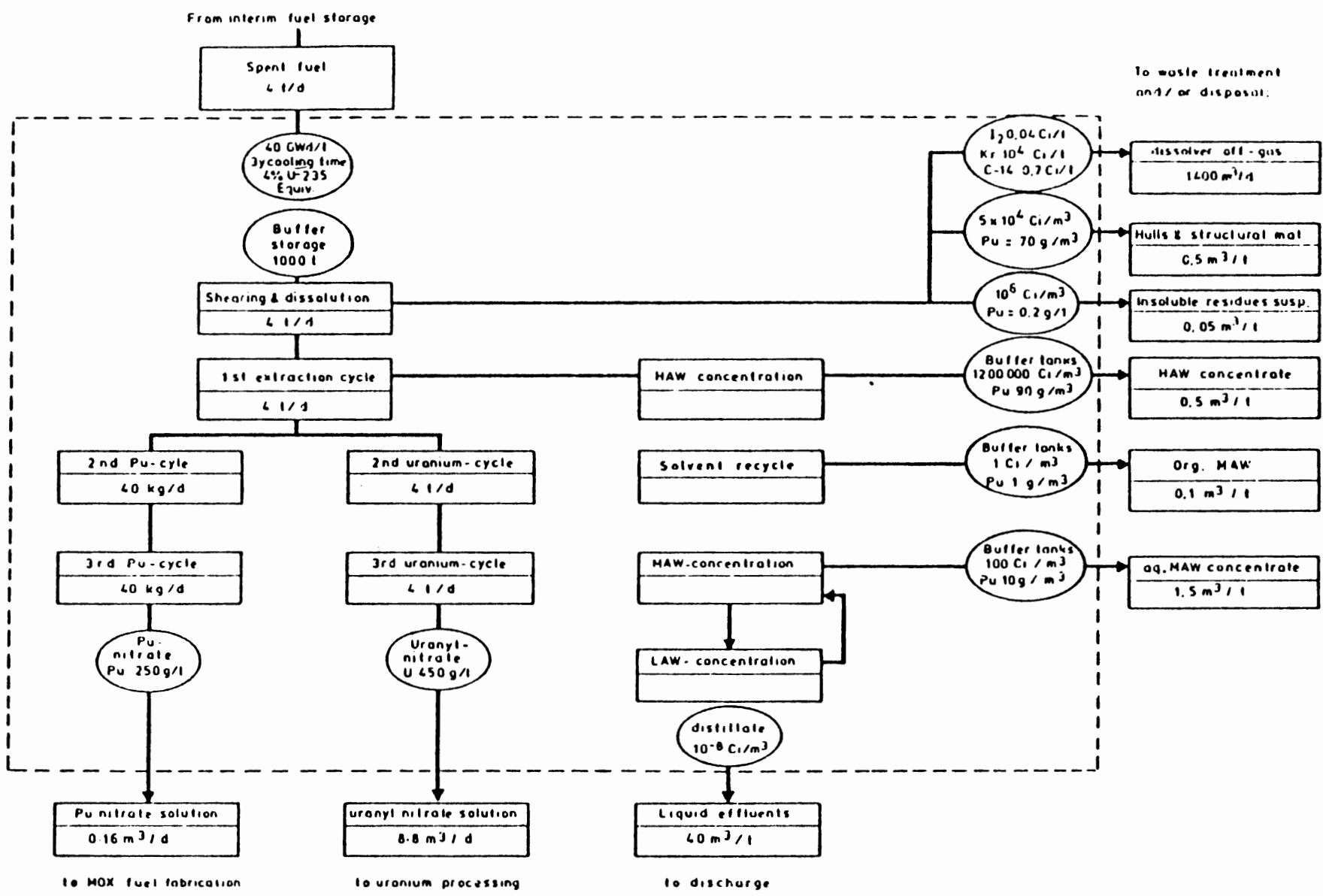

FIGURE A.1. Reference Reprocessing Plant--Simplified Flow Diagram(128) 


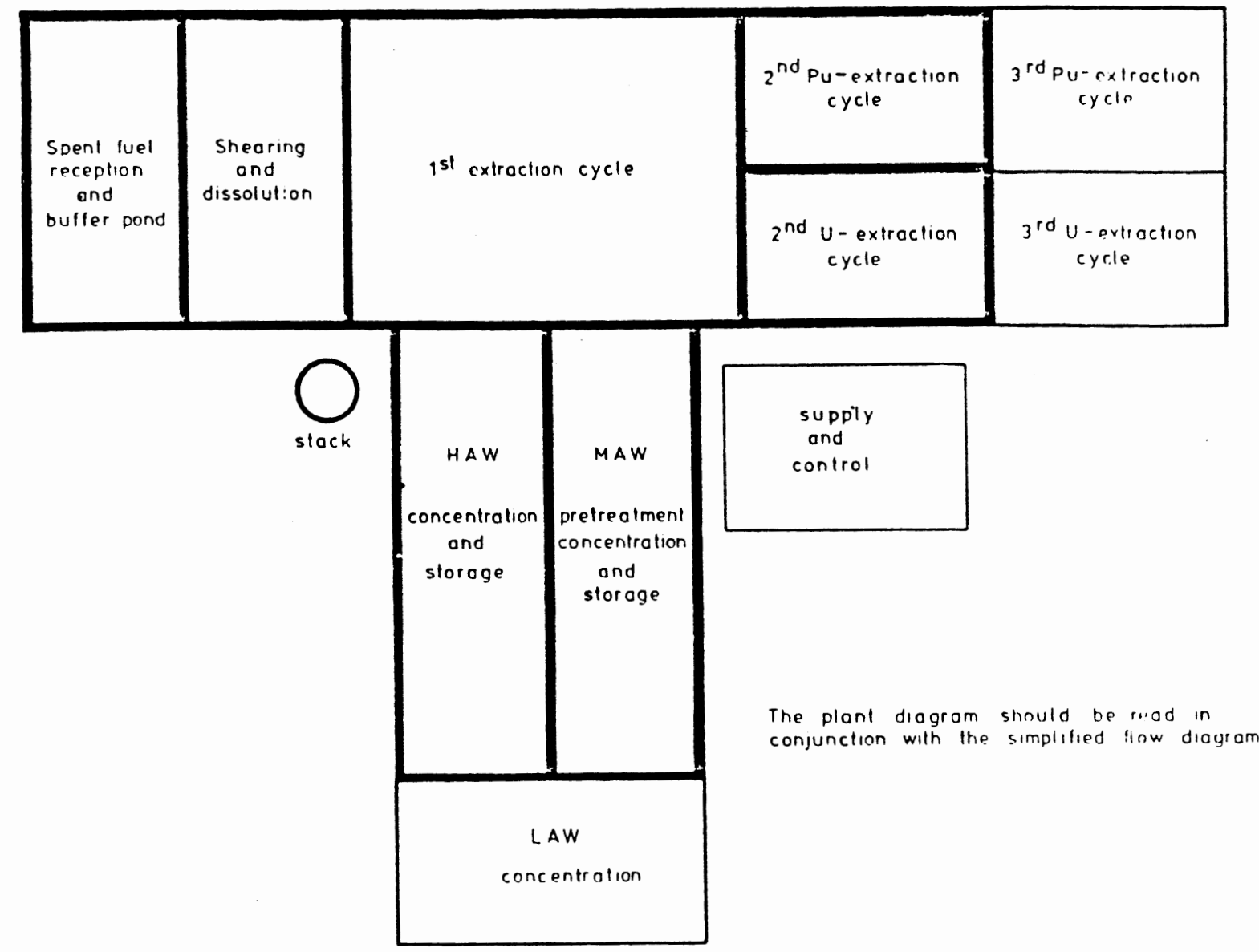

FIGURE A.2. Reference Reprocessing Plant Layout (128)

In such cases, in-cell maintenance requires reduction of radiation levels to the point that human entry into the cell is feasible. For high burnup oxide fuels, the design philosophy is often selected to provide for lifetime reliability of most components, e.g., those in the solvent extraction system, coupled with replaceability of certain highly active components, e.g., the shear and dissolver.

The INFCE study (128) defined a construction schedule for a reference reprocessing plant as shown in Figure A.3. An estimated nine years are required to progress from the start of planning to the start of capacity testing and an additional two years to full commercial operation. Current U.S. experience shows that in this country this time line can be a factor of two short. 


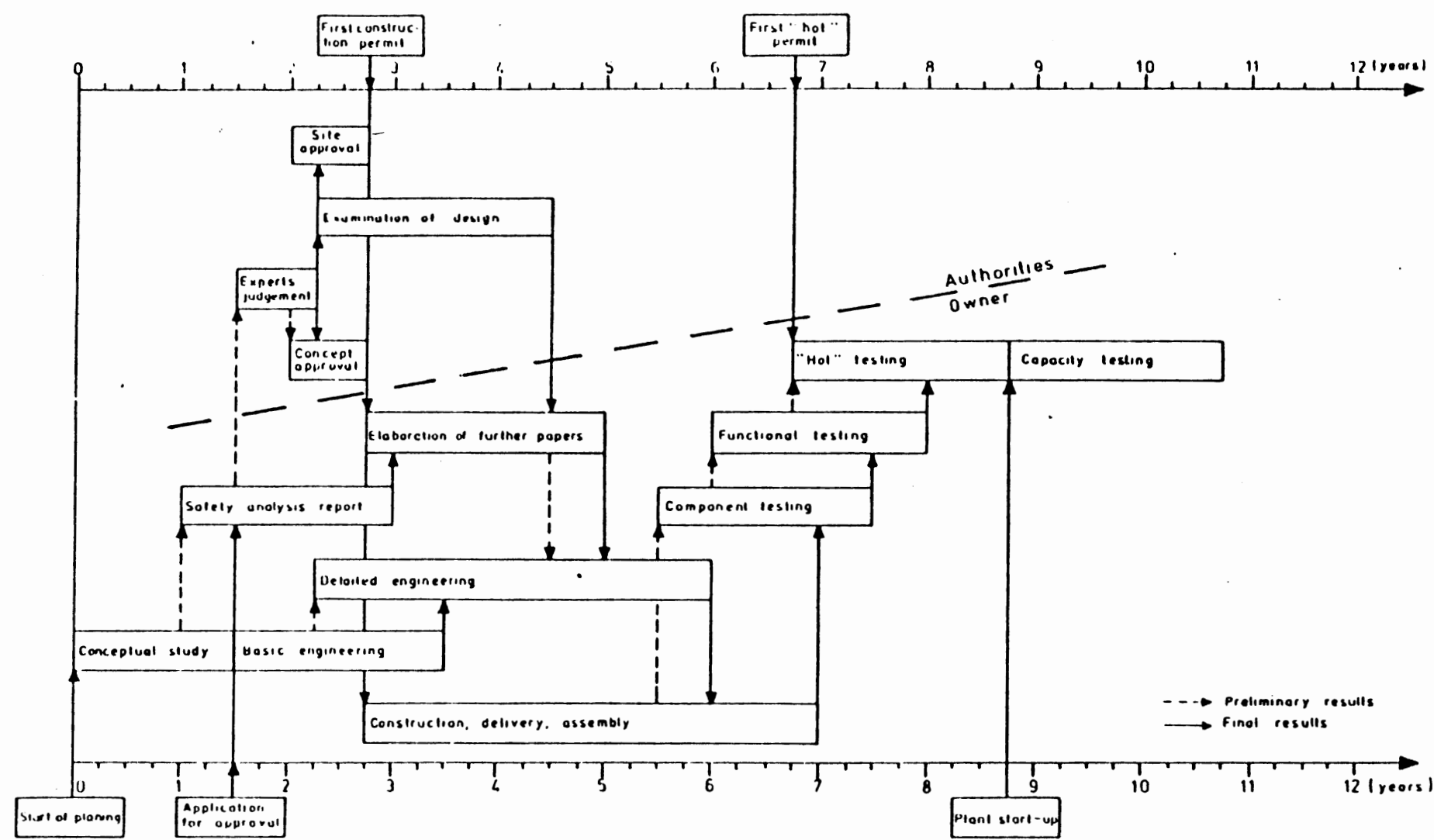

FIGURE A.3. Construction Schedule for Reference Reprocessing Plant(128) 
MANAGEMENT OF REPROCESSING WASTES

A spent fuel reprocessing plant produces a variety of radioactive waste materials: cladding hulls and fuel assembly structural materials; process offgas, which carries radioactive particulates and the gaseous radionuclides (principally tritium, ${ }^{14} \mathrm{C},{ }^{85} \mathrm{Kr}$ and ${ }^{129} \mathrm{I}$ ) released when the fuel is dissolved; insoluble materials left in suspension when the fuel is dissolved; high-level waste concentrate; intermediate-level waste concentrates; and spent organic solvent, and miscellaneous solid wastes.

Various waste management techniques have been devised:

1. Iodine is removed from dissolver off-gas streams by various gasscrubbing techniques, and processes have been developed for collection and immobilization of krypton. Tritium could be removed by a dry process prior to dissolution or by isolating the tritium in the highly active parts of the aqueous system to be further treated and trapped from the overhead condensate as the wastes are evaporated. No large scale application has ever been done to remove tritium, and no requirements for removal now exist. High-efficiency filter systems are used to recover particulates from process and ventilation gaseous effluents.

2. Fuel hulls and dissolver residues may be packaged as is or embedded in concrete prior to disposal. Processes for consolidation by melting or by mechanical compaction have been tested, but not applied commercially. Studies have also been made of the recovery of valuable by-products, such as scarce noble metals, from the dissolver residues.

3. High-level wastes (HLW) are stored in large tanks until they can be solidified. The US has been calcining this type of waste from specialty reactor fuels for many years at the Idaho Chemical Processing Plant, but conversion to a glass form is the current process of choice for HLW from fuel reprocessing. 
4. Intermediate-level wastes are solidified in concrete, bitumen or an organic polymer prior to disposal. Spent solvents are burned or fixed in an absorbent prior to disposal.

5. Solid radioactive wastes appear in many forms--trash, clothing, tools, used equipment, vessels, etc. Combustible wastes are compacted or burned. Residues may be fixed in concrete or bitumen. Equipment and vessels are cut down in size in hot cells for packaging.

A feeling for the magnitude of the associated waste disposal problem may be gained from the following German estimates of the waste volumes from reprocessing the spent fuel produced in one year's operation of a 1200-MWe power station: (129)

- Vitrified HLW

- Cemented ILW and LLW

- $3_{H \text {-bearing liquid effluents }}$

$\begin{array}{rl}4 \mathrm{~m}^{3} & 16 \times 10^{6} \mathrm{Ci} \\ 200 \mathrm{~m}^{3} & 1 \times 10^{6} \mathrm{Ci} \\ 100 \mathrm{~m}^{3} & 0.1 \times 10^{6} \mathrm{Ci}\end{array}$


APPENDIX B

ADVANCED PILOT PLANT, COMMERCIAL, AND MILITARY REPROCESSING FACILITIES 


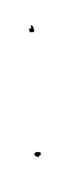


TABLE B.1. Advanced Pilot Plant, Commercial and Military Reprocessing Facilities

\begin{tabular}{|c|c|c|c|}
\hline $\begin{array}{l}\text { Country } \\
\text { Plant } \\
\text { (name, site) }\end{array}$ & $\begin{array}{l}\text { BELGIUM } \\
\text { Eurochemic } \\
\text { Mol }\end{array}$ & $\begin{array}{l}\text { FRANCE } \\
\text { UP-1 } \\
\text { Marcoule }\end{array}$ & $\begin{array}{l}\text { FRANCE } \\
\text { UP-2 } \\
\text { La Hague. }\end{array}$ \\
\hline Owner & $\begin{array}{l}\text { Eurochemic (joint company of } \\
\text { originally } 12 \text { OECD member states) }\end{array}$ & Cogéma & Cogéma \\
\hline Operator & same & same & same \\
\hline Start of construction & 1962 & 1955 & 1962 \\
\hline Period of operation & $1966-1974$ & 1958-present & $\begin{array}{l}\text { 1966-present, GCR fuels; } \\
19 \text {-present, LWR \& FBR fuels } \\
\text { (HAO head end) }\end{array}$ \\
\hline Fuel type & $\begin{array}{l}\text { low-enriched metal, alloy and } \\
\text { oxide fuels; high-enriched fuels }\end{array}$ & natural $U$ metal & \\
\hline Design capacity (t/d) & 0.44 & 4.5 to 6 & 5 natural $U, 1.3$ oxide fuel \\
\hline Hear-end & $\begin{array}{l}\text { high-enriched U-Al fuels: } \\
\text { co-dissolution of fuel and clad- } \\
\text { ding; other fuels: chemical } \\
\text { decladding, separate dissolution } \\
\text { of fuel }\end{array}$ & $\begin{array}{l}\text { mechanical decladding, batch U } \\
\text { dissolution; continuous dis- } \\
\text { solution after } 1964\end{array}$ & $\begin{array}{l}\text { mechanical decladding installed } 1976 \text {, } \\
\text { continuous U dissolution }\end{array}$ \\
\hline Process & Purex, 2 or 3 cycle & $\begin{aligned} \text { Purex } & 2 \text { cycles } U \\
& 2 \text { cycles } \mathrm{Pu}\end{aligned}$ & $\begin{array}{l}\text { Purex } 2 \text { cycles } U \\
3 \text { cycles } \mathrm{Pu}_{u}\end{array}$ \\
\hline TBP concen. (Vol. \%) & $\begin{array}{l}30 \text { (low-enriched fuels); } 5 \text { (high- } \\
\text { enriched fuels) }\end{array}$ & 30 (before 1961:40) & 30 \\
\hline Extractor type & $\begin{array}{l}\text { pulsed columns; mixer-settlers on } \\
\text { Pu purification cycles }\end{array}$ & $\begin{array}{l}\text { mixer-settlers (U cycles) } \\
\text { pulsed columns (Pu final cycle) }\end{array}$ & $\begin{array}{l}\text { mixer-sett lers; multi-stage centrifugal } \\
\text { contactor in HAO for first cycle co- } \\
\text { extraction }\end{array}$ \\
\hline Criticality control & $\begin{array}{l}\text { geometry concentration, hetero- } \\
\text { geneous poisoning }\end{array}$ & concentration, geometry & concentration, geometry \\
\hline Maintenance concept & contact & contact & contact \\
\hline \multirow[t]{3}{*}{ Special features, remarks } & $\begin{array}{l}\text { multi-purpose plant operation } \\
\text { terminated on schedule in } 1974 ; \\
\text { plant decontaminated for modifi- } \\
\text { cations and repairs and ownership } \\
\text { transferred to Belgium. }\end{array}$ & $\begin{array}{l}\text { Pu final purification originally } \\
\text { by } 30 \% \text { RP flowsheet in mixer- } \\
\text { settlers, was replaced in } 1967 \text { by } \\
20 \% \text { TBP reflux flowsheet in pulsed } \\
\text { columns system. }\end{array}$ & $\begin{array}{l}\text { oxide head-end (HAO) comprising chop-leach } \\
\text { dissolution plus centrifugal extractor } \\
\text { since replaced with pulsed colum for } 1 \text { st } \\
\text { cycle started operation in. }\end{array}$ \\
\hline & $\begin{array}{l}\text { Belgian senate approval obtained } \\
\text { April } 1983 \text { for operation by Belgian } \\
\text { company; new chop-leach head-end } \\
\text { for LWR Mox fuels to be installed; } \\
\text { startup planned for } 1986 \text {. }\end{array}$ & $\begin{array}{l}\text { Original reductant } \mathrm{U}\left(\mathrm{SO}_{4}\right)_{2}+ \\
\mathrm{HSO}_{3} \mathrm{NH}_{2}, \text { was replaced in } 1963 \\
\text { by } \mathrm{O}_{\left(\mathrm{NO}_{3}\right)_{4}+\mathrm{N}_{2} \mathrm{H}_{4} \text {. }}\end{array}$ & $\begin{array}{l}\text { 1976. Capacity is } 400 \mathrm{t} / \mathrm{yr} \text { at present, } \\
\text { will be scaled up to } 800 \mathrm{t} / \mathrm{yr} \text { in } 1981 \text {. }\end{array}$ \\
\hline & & Np-237 also recovered. & $\begin{array}{l}\text { Pu tail-end originally by tertiary amine } \\
\text { extraction, has been converted to TBP } \\
\text { extraction in } 1974 \text {. }\end{array}$ \\
\hline Tonnes processed & $\begin{array}{l}200 \mathrm{t} \text { low-enriched } U \\
30 \mathrm{t} \text { high-enriched } U(1966-1974)\end{array}$ & $12,000 \mathrm{t}(1958-1983)$ & $\begin{array}{l}4,150 \text { t } U \text { metal }(1966-1981) \\
730 \text { t oxide }(1976-1983)\end{array}$ \\
\hline
\end{tabular}




\section{TABLE B.1. (contd)}

\begin{tabular}{|c|c|c|c|}
\hline $\begin{array}{l}\text { Country } \\
\text { Plant } \\
\text { (name, site) }\end{array}$ & $\begin{array}{l}\text { GERMANY (FRG) } \\
\text { WAK } \\
\text { Wiederaufarbeitungsanlage, Karlsruhe }\end{array}$ & $\begin{array}{l}\text { GERMANY (FRG) } \\
\text { Wackersdorf and Dragahn sites }\end{array}$ & $\begin{array}{l}\text { INUIA } \\
\text { Trombay Fuel Reprocessing Plant } \\
\text { Irombay, Bombay }\end{array}$ \\
\hline Owner & DHK (KfK until 1978) & DWK & Indian AEC \\
\hline Operator & same & same & same \\
\hline Start of construction & 1967 & $\begin{array}{l}\text { application for construction permit } \\
\text { for two plants has been submitted }\end{array}$ & 1961 \\
\hline Period of operation & $\begin{array}{l}1971-1980 \\
1982 \text {-present }\end{array}$ & $\begin{array}{l}\text { construction permit anticipated in } \\
\text { late } 1984\end{array}$ & 1964-1974; \\
\hline Fuel type & low-enriched $\mathrm{VO}_{2}$ (LWR fuels) & low-enriched $\mathrm{UO}_{2}$ (LWR fuel) & natural $U$ metal, Al-clad \\
\hline Design capacity $(t / d)$ & 0.18 & & 0.25 \\
\hline Head-end & mechanical disassembly, chop-leach & chop-leach & chemical decladding, $U$ dissolution \\
\hline Process & Purex, 3 cycle & Purex, 3 cycle & Purex, 3 cycle \\
\hline TBP concen. ( Vol. $x$ ) & 30 & 30 & 30 \\
\hline Extractor type & mixer-settlers & $\begin{array}{l}\text { pulsed columns, mixer-settlers } \\
\text { (U cycles only) }\end{array}$ & pulsed columns, ion exchange \\
\hline Criticality control & $\begin{array}{l}\text { geometry, concentration, hetero- } \\
\text { geneous poi soning }\end{array}$ & geometry, concentration, poisoning & geometry, concentration \\
\hline Maintenance concept & contact & remote & contact \\
\hline Special features, remarks & $\begin{array}{l}\text { dissolver fallure--1980; plant back } \\
\text { on line October } 1982\end{array}$ & $\begin{array}{l}\text { design calls for processing } 1000 \\
\text { fuel elements/yr with max. burnup } \\
\text { of } 40,000 \text { md/t of } 1.8 \% \text { enriched } \\
\text { Mox fuel cooled for about } 7 \text { years }\end{array}$ & $\begin{array}{l}\text { plant currently being repaired and } \\
\text { modified to increase capacity }\end{array}$ \\
\hline Tonnes processed & $120 \mathrm{t}(1971-1980)$ & & \\
\hline Plutonium separated & $568 \mathrm{~kg}$ & & \\
\hline
\end{tabular}




\begin{tabular}{|c|c|c|c|}
\hline $\begin{array}{l}\text { Country } \\
\text { Plant } \\
\text { (name, site) }\end{array}$ & $\begin{array}{l}\text { INó́A } \\
\text { Tarapur Fuel Reprocessing Plant } \\
\text { Tarapur }\end{array}$ & $\begin{array}{l}\text { IALY } \\
\text { ITREC Plant } \\
\text { Irisaia Center }\end{array}$ & $\begin{array}{l}\text { ITALY } \\
\text { EUREX Plant } \\
\text { Saluggia Center }\end{array}$ \\
\hline Owner & - Indian AEC & & \\
\hline Operator & same & & \\
\hline Start of construction & 1969 & 1965 & \\
\hline Period of operation & $\begin{array}{l}\text { 1978, test operation; idle unt il } \\
\text { December } 1982\end{array}$ & 1975 & 1970-1974 \\
\hline Fuel type & $\begin{array}{l}\text { nat. or low-enriched } \mathrm{UO}_{2} \text { (CANDU } \\
\text { and LW fuels) }\end{array}$ & $\mathrm{ThO}_{2}+\mathrm{UO}_{2}$ fuel & $\begin{array}{l}\text { highly enriched MTR fuel natural } \\
\text { and low-enrichment } 0\end{array}$ \\
\hline Design capacity ( $t / d$ ) & 0.5 & $15 \mathrm{~kg} / \mathrm{d}$ & $30 \mathrm{~kg} / \mathrm{d}$ MTR $100 \mathrm{~kg} / \mathrm{d}$ LEV fuel \\
\hline Head-end & chop-leach & chop-leach & \\
\hline Process & Purex, multi-cycle & Thorex, 1 cycle & Purex, 2 cycle \\
\hline TBP concen. (Vol. ‡) & 30 & 30 & -- \\
\hline Extractor type & pulsed colums & slab mixer-settler & mixer-settlers \\
\hline Criticality control & $\begin{array}{l}\text { not published, probably geometry } \\
\text { and concentration }\end{array}$ & geometry accountability control & $\begin{array}{l}\text { silica gel final decontamination } \\
\text { of } U \text {, tert fary amine extraction } \\
\text { for final Pu }\end{array}$ \\
\hline Maintenance concept & contact & & contact \\
\hline
\end{tabular}

Special features, remarks plant also recovers neptunium

Tonnes processed 
TABLE B.1. (contd)

\begin{tabular}{|c|c|c|c|}
\hline $\begin{array}{l}\text { Country } \\
\text { Plant } \\
\text { (name, site) }\end{array}$ & $\begin{array}{l}\text { JAPAN } \\
\text { Tokai-mura } \\
\text { Iokai } \\
\end{array}$ & $\begin{array}{l}\text { UK } \\
\text { Butex } \\
\text { Sellafield } \\
\end{array}$ & $\begin{array}{l}\text { UK } \\
\text { Magnox } \\
\text { Sellafield }\end{array}$ \\
\hline Owner & $\begin{array}{l}\text { Power Reactor \& Nuclear Fuel } \\
\text { Devel opment Corporation (PNC) }\end{array}$ & BNFL & BNFL \\
\hline Operator & same & same & same \\
\hline Start of construction & 1971 & & \\
\hline Period of operation & $\begin{array}{l}1977-1980 \text { (test operation) } \\
\text { 1980-present }\end{array}$ & 1952-1964 & $\begin{array}{l}\text { 1964-present, GCR fuels } \\
1974 \text {, kHe (oxide) fuels }\end{array}$ \\
\hline Fuel type & $\begin{array}{l}\text { low-enriched } \mathrm{UO}_{2} \text { (LWR fuel); } \\
\text { natural U umetal (Calder-Hali-type } \\
\text { and research reactors }\end{array}$ & natural U alloy (Magnox fuel) & 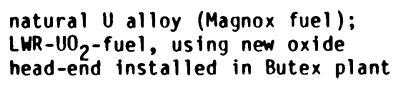 \\
\hline Design capacity ( $t / d$ ) & 0.7 & 1.5 after 1969 & $5-8$ \\
\hline Head-end & $\begin{array}{l}\text { mechanical decladding, chemical } \\
\text { dissolution (metal fuels); chop- } \\
\text { leach (LKR fuels) }\end{array}$ & $\begin{array}{l}\text { mechanical decladding, continuous } \\
\text { dissolution }\end{array}$ & $\begin{array}{l}\text { mechanical decladding, continuous } \\
\text { dissolution }\end{array}$ \\
\hline Process & Purex, 3 cycle & Butex & Purex, 3 or 4 cycle \\
\hline TBP concen. (Vol. $x)$ & 30 & -- & 20 \\
\hline Extractor type & mixer-settlers & dibutyl carbitol (Butex) & mixer-settlers \\
\hline Criticality control & $\begin{array}{l}\text { geometry, concentration, hetero- } \\
\text { geneous poison (tanks only) }\end{array}$ & -- & $\begin{array}{l}\text { concentration, geometry (Pu cycles } \\
\text { only), batch size (oxide head-end } \\
\text { only) }\end{array}$ \\
\hline Maintenance concept & $\begin{array}{l}\text { remote - head-end } \\
\text { contact - rest of plant }\end{array}$ & -- & contact \\
\hline Special features, remarks & no intercycle evaporation used & $\begin{array}{l}\text { chop-leach installed in the new } \\
\text { Butex head-end facility in } 1968\end{array}$ & $\begin{array}{l}\text { 0xide Head-End Plant comprising } \\
\text { chop-leach dissolution plus one } \\
\text { cycle of Butex-coextraction was } \\
\text { installed in Butex plant for LRR } \\
\text { oxide fuel processing; plant shut } \\
\text { down in } 1973 \text { as a result of an } \\
\text { incident that released a small } \\
\text { amount of } 106 \text { Ru; plant modified } \\
\text { and due to restart about } 1985 \\
\text { No intercycle evaporation in } \\
\text { Purex system }\end{array}$ \\
\hline Tonnes processed & $175(1977-1983)$ & $\begin{array}{c}20,000 \text { tU metal }(1952-1973) \\
90 \text { t oxide }(1969-1973)\end{array}$ & $\begin{array}{l}18,000 \text { tU metal }(1964-1977) \\
400 \mathrm{t} \text { oxide }\end{array}$ \\
\hline Plutonium separated & $1000 \mathrm{~kg}$ & & \\
\hline
\end{tabular}


TABLE B.1. (contd)

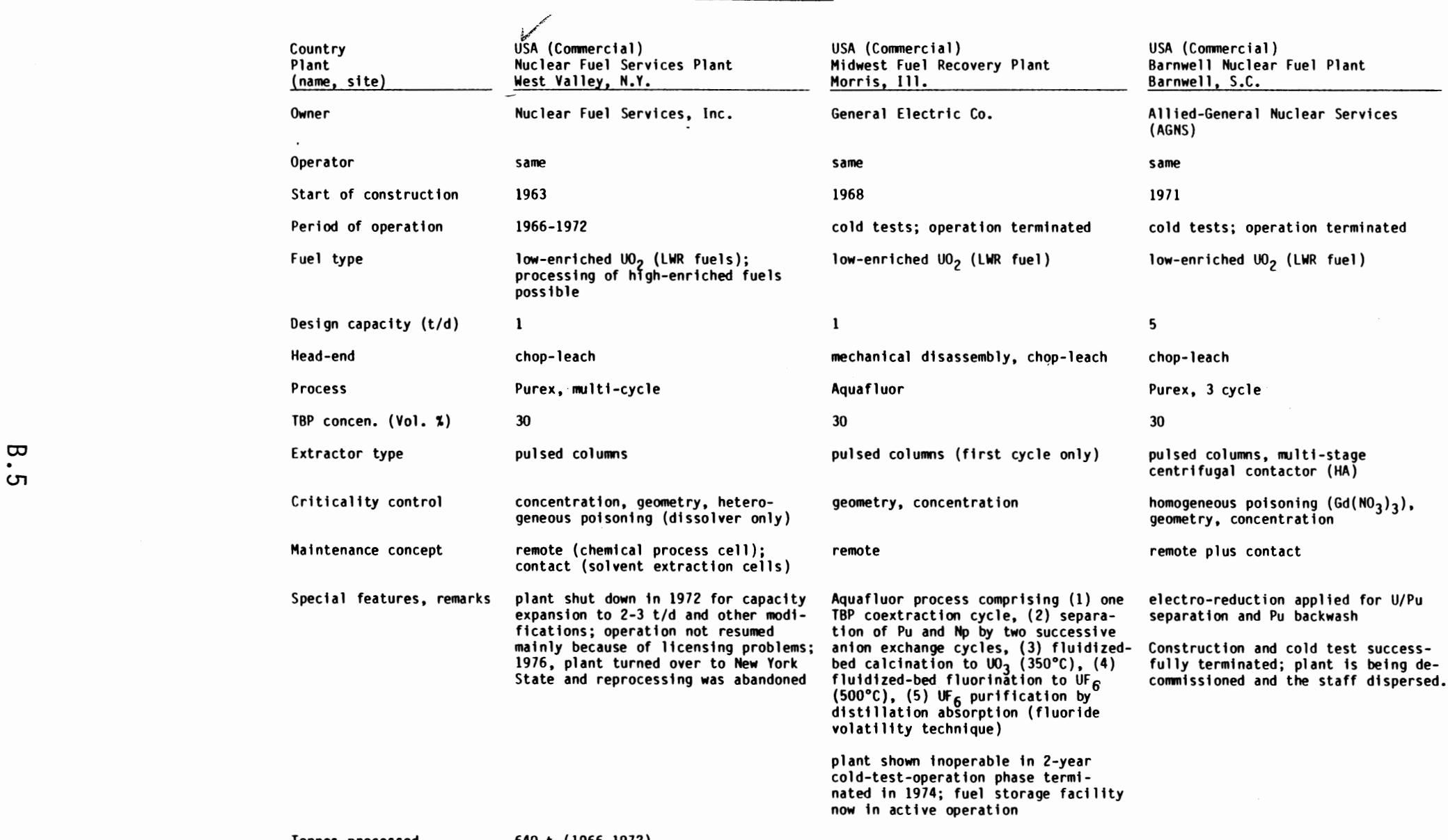




\section{TABLE B.1. (contd)}

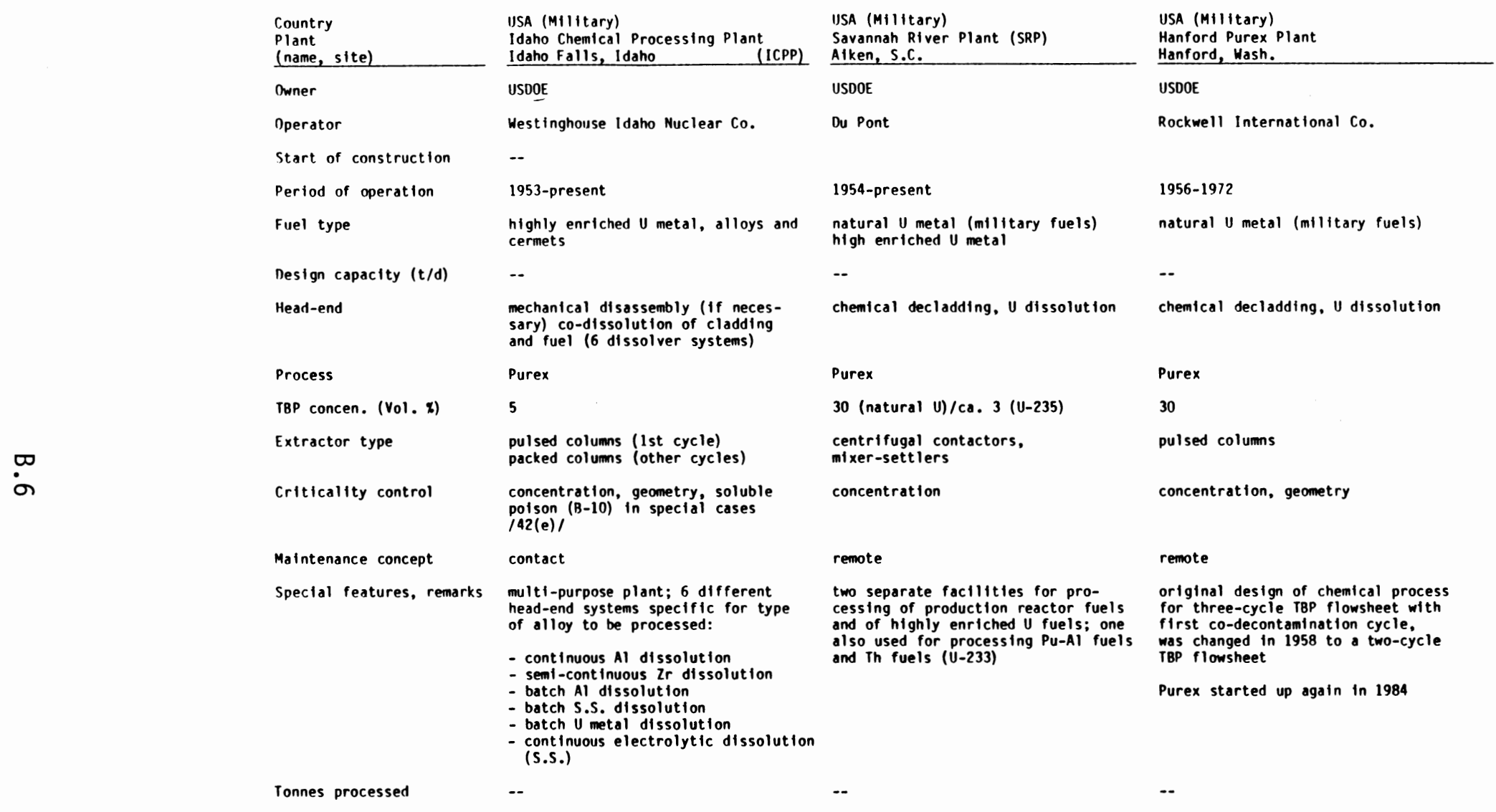


No. of

Copies

OFFSITE

\section{DOE HEADQUARTERS}

K. D. Ize11, GC-42

Office of the General

Counsel

U.S. Department of Energy

Forrestal

Washington, DC 20585

S. K. Kuznick, GC-32

Office of the General

Counsel

U.S. Department of Energy

Forrestal

Washington, DC 20585

J. A. Dugger, IE-22

U.S. Department of Energy Forrestal

Washington, DC 20585

S. Griffith, IE-22

U.S. Department of Energy

Forrestal

Washington, DC 20585

H. Jaffe, IE-20

U.S. Department of Energy

Forrestal

Washington, DC 20585

M. D. McDonough, IE-21

U.S. Department of Energy Forrestal

Washington, DC 20585

T. K. Lau, IE-22

U.S. Department of Energy Forrestal

Washington, DC 20585

W. Porter, IE-21

U.S. Department of Energy Forrestal

Washington, DC 20585

R. E. Robertson, IE-21

U.S. Department of Energy Forrestal

Washington, DC 20585

K. W. Wentzel, IE-20

U.S. Department of Energy Forrestal

Washington, DC 20585
No. of

Copies

A. K. Flieger, DP-333

U.S. Department of Energy

Forrestal

Washington, DC 20585

R. F. Kott, DP -333

U.S. Department of Energy

Forrestal

Washington, DC 20585

F. A. Minton, Jr., DP -333

U.S. Department of Energy

Forrestal

Washington, DC 20585

R. L. Morgan, DP-1

U.S. Department of Energy

Forrestal

Washington, DC 20585

R. D. Nelson, DP-331

U.S. Department of Energy Forrestal

Washington, DC 20585

G. H. Daly, DP-10

U.S. Department of Energy GTN

Washington, DC 20545

J. E. Dieckhoner, DP-122

U.S. Department of Energy GTN

Washington, DC 20545

R. K. Heusser, DP -132

U.S. Department of Energy GTN

Washington, DC 20545

J. J. Jicha, DP-123

U.S. Department of Energy GTN

Washington, DC 20545

D. B. LeClaire, DP-12

U.S. Department of Energy GTN

Washington, DC 20545

R. S. Scott, DP-121

U.S. Department of Energy GTN

Washington, DC 20545
No. of

Copies

A. L. Taboas, DP-123

U.S. Department of Energy GTN

Washington, DC 20545

R. D. Walton, Jr, DP-123

U.S. Department of Energy GTN

Washington, DC 20545

L. R. Willett, DP-132

U.S. Department of Energy GTN

Washington, DC 20545

S. T. Brewer, NE-1

U.S. Department of Energy

Forrestal

Washington, DC 20585

P. A. Garon, NE-72

U.S. Department of Energy

Forrestal

Washington, DC 20585

S. Rosen, NE-75

U.S. Department of Energy

Forrestal

Washington, DC 20585

D. E. Bailey, NE-42

U.S. Department of Energy GTN

Washington, DC 20545

5 C. B. Bastin, Jr., NE-42

U.S. Department of Energy GTN

Washington, DC 20545

J. E. Baublitz, NE-24

U.S. Department of Energy GTN

Washington, DC 20545

R. B. Chitwood, NE -43

U.S. Department of Energy GTN

Washington, DC 20545

F. E. Coffman, NE-20

U.S. Department of Energy GTN

Washington, DC 20545 
No. of

Copies

J. A. Coleman, NE-25

U.S. Department of Energy GTN

Washington, DC 20545

E. G. Delaney, NE-24

U.S. Department of Energy GTN

Washington, DC 20545

F. Goldner, NE-75

U.S. Department of Energy GTN

Washington, DC 20545

K. E. Horton, NE-75

U.S. Department of Energy GTN

Washington, DC 20545

3 K. 0. Laughon, NE -40

U.S. Department of Energy GTN

Washington, DC 20545

D. J. McGoff, NE-23

U.S. Department of Energy GTN

Washington, DC 20545

W. H. McVey, NE-42

U.S. Department of Energy GTN

Washington, DC 20545

H. H. Rohm, NE -50

U.S. Department of Energy GTN

Washington, DC 20545

H. E. Stelling, NE-42

U.S. Department of Energy GTN

Washington, DC 20545

J. A. Turi, NE-25

U.S. Department of Energy GTN

Washington, DC 20545

K. A. Klein, RW-32

U.S. Department of Energy Forrestal

Washington, DC 20585

A. F. Perge, RW-43

U.S. Department of Energy Forrestal

Washington, DC 20585
No. of

Copies

C. R. Cooley, RW-24

U.S. Department of Energy GTN

Washington, DC 20545

J. J. Fiore, RW-22

U.S. Department of Energy GTN

Washington, DC 20545

DOE OPERATIONS

D. G. Boyer

Albuquerque Operations office

U.S. Department of Energy

P.0. Box 5400

Albuquerque, NM 87115

D. Campbell

Albuquerque Operations office

U.S. Department of Energy

P.0. Box 5400

Albuquerque, NM 87115

J. McGough

Albuquerque Operations office

U.S. Department of Energy

P.0. Box 5400

Albuquerque, NM 87115

H. J. Rauch (Manager)

Chicago Operations Office

U.S. Department of Energy

9800 South Cass Avenue

Argonne, IL 60439

\section{S. A. Mann}

Chicago Operations Office U.S. Department of Energy 9800 South Cass Avenue

Argonne, IL 60439

J. 0. Neff

National Waste Program office

U.S. Department of Energy $505 \mathrm{King}$ Avenue

Columbus, $\mathrm{OH} 43201$

H. J. Argyle

Idaho Operations Office

U.S. Department of Energy

550 Second Street

Idaho Falls, ID 83401
No. of

Copies

M. J. Barainca

Idaho Operations office

$U . S$. Department of Energy

550 Second Street

Idaho Falls, ID 83401

E. Maestas

Idaho Operations Office

U.S. Department of Energy

550 Second Street

Idaho Falls, ID 83401

T. E. Wade, II (Manager)

Idaho Operations Office

U.S. Department of Energy

550 Second Street

Idaho Falls, ID 83401

C. P. Gertz

Idaho Operations Office

U.S. Department of Energy

550 Second Street

Idaho Falls, ID 83401

R. D. Duncan

Nevada Operations Office

U.S. Department of Energy

Las Vegas, NV 89114-4100

D. L. Vieth

Nevada Operations Office

U.S. Department of Energy

Las Vegas, NV 89114-4100

S. Ahrends

Oak Ridge Operations

Office

U.S. Department of Energy

P.0. Box E

Oak Ridge, TN 37830

J. LaGrone (Manager)

Oak Ridge Operations office

U.S. Department of Energy

P.0. Box E

Oak Ridge, TN 37830

R. Philippone

Oak Ridge Operations Office

U.S. Department of Energy

P.0. Box E

Oak Ridge, TN 37830

L. Lanni

San Francisco Operations Office

U.S. Department of Energy

1333 Broadway, Wells Fargo Building

0akland, CA 94612 
No. of

W. J. Brumley

Savannah River Operations Office

U.S. Department of Energy

P.0. Box A

Aiken, SC 29801

G. K. 0ertel

Savannah River Operations Office

U.S. Department of Energy

P.0. Box A

Aiken, SC 29801

H. B. Saucier

Savannah River Operations Office

U.S. Department of Energy

P.0. Box A

Aiken, SC 29801

W. Hannum

West Valley Project Office

U.S. Department of Energy

P.0. Box 191

West Valley, NY 14171-0191

Technical Library

West Valley Project Office

U.S. Department of Energy

P.0. Box 191

West Valley, NY 14171-0191

Office of Technical and Scientific Information

P.0. Box 62

Oak Ridge, TN 37830

DOE CONTRACTORS

L. Burris

Argonne National

Laboratory

9700 South Cass Avenue

Argonne, IL 60439

J. H. Kittel, OTD, Bldg. 208

Argonne National Laboratory

9700 South Cass Avenue

Argonne, IL 60439

M. J. Steindler, CMT-205

Argonne National

Laboratory

9700 South Cass Avenue

Argonne, IL 60.439
No. of

Copies

S. M. Nealey

Battelle Memorial

Institute

Human Affairs Research

Centers

4000 NE 41st Street

P.0. Box 5395

Seattle, WA 98105

C. R. Schuller

Battelle Memorial

Institute

Human Affairs Research Centers

4000 NE 41st Street

Seattle, WA 98105

Library

ATTN: Barbara Keen

Battelle Memorial

Institute

Human Affairs Research Centers

$4000 \mathrm{NE} 41$ st Street

Seattle, WA 98105

L. A. Rancitelli

Battelle Memorial

Institute

505 King Ave.

Columbus, $\mathrm{OH} 43201$

P. Colombo, B1dg. 701

Brookhaven National

Laboratory

Upton, NY 11973

NWM Library

ATTN: S. G. Lane, Bldg. 830

Brookhaven National

Laboratory

Upton, NY 11973

G. R. Vineyard

Brookhaven National

Laboratory

Upton, NY 11973

G. F. Curtin

Atomic Energy Division

E. I. Du Pont de Nemours \&

Co., Inc.

6600 Montchanin Building

Wilmington, DE 19898
No. of

Copies

Document Custodian

Atomic Energy Division

E. I. Du Pont de Nemours \&

Co., Inc.

6600 Montchanin Building

Wilmington, DE 19898

E. A. Jennrich

EG\&G Idaho, Inc.

P.0. Box 1625

Idaho Falls, ID 83415

D. L. Uh1, WCB E-2

EG\&G Idaho, Inc.

P.0. Box 1625

Idaho Falls, ID 83415

B. J. Baxter

G. A. Technologies, Inc. P.0. Box 81608

10955 John Day Hopkins Drive

San Diego, CA 92138

D. M. Kerr, Director

Los Alamos National Laboratory

P.0. Box 1663

Los Alamos, NM 87545

2 Report Library, MS-P364

Los Alamos National Laboratory

P.0. Box 1663

Los Alamos, NM 87545

D. T. Oakley, MS 671

Los Alamos National

Laboratory

P.0. Box 1663

Los Alamos, NM 87545

L. D. Ramspott, L-204

Lawrence Livermore

National Laboratory

University of California

P.0. Box 808

Livermore, CA 94550

Technical Information Department, L-53

Lawrence Livermore National Laboratory University of California

P.0. Box 808

Livermore, CA 94550 
No. of

Copies

J. 0. Blomeke

Oak Ridge National

Laboratory

P.0. Box $X$

Oak Ridge, TN 37831

W. D. Burch

Oak Ridge National

Laboratory

P.0. Box $X$

Oak Ridge, TN 37831

M. Feldman

Oak Ridge National

Laboratory

P.0. Box X

Oak Ridge, TN 37831

H. W. Godbee

Oak Ridge National

Laboratory

P.0. Box X

Oak Ridge, TN 37831

L. J. Mezga,

Bldg. 1505/106

Oak Ridge National

Laboratory

P.0. Box X

Oak Ridge, TN 37831

H. Postma

Oak Ridge National

Laboratory

P.0. Box X

Oak Ridge, TN 37831

T. H. Row, Bldg. 4500-N, C-36

Oak Ridge National

Laboratory

P.0. Box X

Oak Ridge, TN 37831

3 J. G. Stradley,

Bldg. 7601, MS 002

Oak Ridge National

Laboratory

P.0. Box X

Oak Ridge, TN 37831

D. B. Trauger

Oak Ridge National

Laboratory

P.0. Box X

Oak Ridge, TN 37831
No. of

Copies

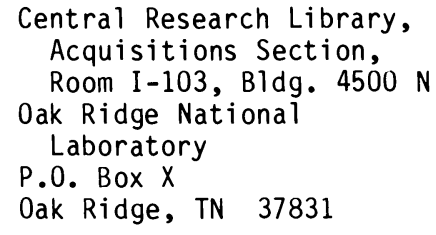

G. W. Meyers

Atomics International Division

Rockwell International

8900 De Soto Avenue

Canoga Park, CA 91304

K. V. Gilbert

Rocky Flats Plant

Rockwell International

Corporation

P.0. Box 464

Golden, C0 80401

P. G. Hagen

Rocky Flats Plant

Rockwell International

Corporation

P.0. Box 464

Golden, C0 80401

M. E. Spaeth

Science Applications, Inc. 2769 South Highland

Las Vegas, NV 89109

D. R. Anderson

Sandia National

Laboratories

P.0. Box 5800

Albuquerque, NM 87185

R. M. Jefferson

Sandia National

Laboratories

P.0. Box 5800

Albuquerque, NM 87185

Technical Library

Sandia National

Laboratories

P.0. Box 5800

Albuquerque, NM 87185

R. W. Lynch

Sandia National

Laboratories

P.0. Box 5800

Albuquerque, M 87185
No. of

Copies

W. D. Weart, Dept. 6330

Sandia National

Laboratories

P.0. Box 5800

Albuquerque, NM 87185

E. L. Albenesius, Research Manager

Savannah River Laboratory

E. I. du Pont - SRP

Aiken, SC 29808

J. L. Crandall

Savannah River Laboratory

E. I. du Pont - SRP

Aiken, SC 29808

2 Document Control Group TIS, Bldg. 773A, Room A-0281

Savannah River Laboratory

E. I. du Pont - SRP

Aiken, SC 29808

2 E. J. Hennelly, 773-19A

Savannah River Laboratory

E. I. du Pont - SRP

Aiken, SC 29808

S. Mirshak

Savannah River Laboratory

E. I. du Pont - SRP

Aiken, SC 29808

R. Maher

Savannah River Plant

Aiken, SC 29808

D. L. McIntosh

Savannah River Plant

Aiken, SC 29808

J. H. Saling, Manager, HLW/SFP

Westinghouse Electric Corp.

Waste Technology, Services Division

P.0. Box 10864

Pittsburgh, PA 15236

R. A. Brown

Westinghouse Idaho Nuclear

Co., Inc.

P.0. Box 4000

Idaho Falls, ID 83401 
No. of

Copies

M. P. Johnson

Westinghouse Idaho Nuclear Co., Inc.

P.0. Box 4000

Idaho Falls, ID 83401

B. R. Wheeler

Westinghouse Idaho Nuclear

Co., Inc.

P.0. Box 4000

Idaho Falls, ID 83401

A. Metry

Weston

2301 Research Boulevard

Rockville, MD 20850

J. F. Strahl

Weston

2301 Research Boulevard

Rockville, MD 20850

J. L. Knabenschuh

West Valley Nuclear

Services Co., Inc.

P.0. Box 191

West Valley, NY 14171-0191

OTHER AGENCIES

R. F. Williams

Electric Power Research

Institute

P.0. Box 10412

3412 Hillview Avenue

Palo Alto, CA 94304

Library

General Atomics

Technologies, Inc.

P.0. Box 81608

San Diego, CA 92138

R. N. Drake

General Atomics

Technologies, Inc.

P.0. Box 81608

San Diego, CA 92138

H. W. Paige

International Energy

Associates, Limited

600 New Hampshire

Avenue, NW

Washington, DC 20037

J. A. McBride

E. R. Johnson Associates, Inc.

11702 Bowman Green Drive

Reston, VA 22090
No. of

Copies

FEDERAL AGENCIES

J. P. Colton

U.S. Arms Control and

Disarmament Agency

Washington, DC 20451

W. Grieder, A-106

Environmental Protection Agency

Office of International

Activities

Washington, DC 20460

F. L. Galpin, MC ANR

Environmental Protection Agency

Waste Management Standards Branch

Criteria and Standards

Division

Washington, DC 20460

W. F. Holcomb, MC ANR -460

Environmental Protection Agency

Office of Radiation Programs

401-M Street, S.W.

Washington, DC 20460

G. L. Sjoblom, MC ANR-460

Environmental Protection Agency

Office of Radiation Programs

401-M Street, S.W.

Washington, DC 20460

P. Myers

National Academy of Sciences

Board on Radioactive Waste Management

Room JH-826

2101 Constitution

Avenue, NW

Washington, DC 20418

D. M. Rohrer, MS-359-EW/W

U.S. Nuclear Regulatory Commission

Office of Inspection and Enforcement

Washington, DC 20555
No. of

Copies

D. Burke, MS 406-EWS

U.S. Nuclear Regulatory Commission

Office of International Programs

Washington, DC 20555

M. R. Peterson, MS 414A-EWS

U.S. Nuclear Regulatory Commission

Office of International Programs

Washington, DC 20555

F. Arsenault, MS 1130-SS

U.S. Nuclear Regulatory Commission

Office of Nuclear Regulatory Research

Division of Health, Siting, and Waste Management

Washington, DC 20555

Dr. Jose L. M. Cortez, MS 1130-SS

U.S. Nuclear Regulatory Commission

Office of Nuclear Regulatory Research

Division of Health, Siting, and Waste Management

Washington, DC 20555

J. J. Davis, MS 1130-SS

U.S. Nuclear Regulatory Commission

Office of Nuclear Regulatory Research

Division of Health, Siting, and Waste Management

Washington, DC 20555

Reference Library ATTN: M Conyngham, MS 160

U.S. Nuclear Regulatory Commission

Office of Nuclear Regulatory Research

Division of Health, Siting, and Waste Management

Washington, DC 20555 
No. of

Copies

J. B. Robertson, MS 410 U.S. Geological Survey Office of Radiohydrology Reston, VA 22092

ONSITE

14 DOE Richland Operations Office

T. A. Bauman

P. Brimhall

M. Dayani (6)

R. A. Holten

H. E. Ransom

J. L. Rhoades

G. Schmidtke

J. D. White

M. J. Zamorsky

7 Rockwell-Hanford

C. L. Brown

C. V. Di Pol

P. G. Lorenzini

J. W. Patterson

J. H. Roecker

W. W. Schulz

V. V. Ufkes, Technical Information Center
No. of

Copies

UNC Nuclear Industries

W. J. Kyriazis

5 Westinghouse Hanford Corporation

A. G. Blasewitz

C. A. Burgess

E. A. Evans

R. D. Lerch

S. J. Mayhan

64 Pacific Northwest Laboratory

W. W. Ballard

W. F. Bonner

J. B. Brown

L. L. Burger

D. B. Cearlock

J. M. Davidson

K. M. Harmon (15)

A. B. Johnson, Jr.

R. J. Kofoed

L. T. Lakey (15)
No. of

Copies

I. W. Leigh

R. C. Liikala

J. L. McEl roy

R. B. McKee

P. J. Mellinger (5)

J. E. Mendel

D. R. Oden

A. M. Platt

D. E. Robertson, Jr.

J. V. Robinson

K. J. Schneider

R. G. Schreckhise

H. H. Van Tuy?

E. J. Wheelwright

L. D. Williams

Publishing Coordination (2)

Technical Information (5) 